\title{
Caracterização fenotípica e grau de ativação de células dendríticas plasmocitóides ao estímulo in vitro com oligodeoxinucleotídeos CpG na Urticária Crônica
}

Tese apresentada à Faculdade de Medicina da Universidade de São Paulo para obtenção do título de Doutor em Ciências

Programa de Dermatologia

Orientadora: Profa. Dra. Maria Notomi Sato

\section{São Paulo}




\section{Dados Internacionais de Catalogação na Publicação (CIP)}

Preparada pela Biblioteca da

Faculdade de Medicina da Universidade de São Paulo

Creprodução autorizada pelo autor

Taniguchi, Eliana Akemi Futata

Caracterização fenotípica e grau de ativação de células dendríticas

plasmocitóides ao estímulo in vitro com oligodeoxinucleotídeos CpG na urticária crônica / Eliana Akemi Futata Taniguchi. -- São Paulo, 2010.

Tese(doutorado)--Faculdade de Medicina da Universidade de São Paulo.

Programa de Dermatologia.

Orientadora: Maria Notomi Sato.

Descritores: 1.Urticária 2.Urticária crônica idiopática 3.Imunidade inata 4.Interferon alfa 5.Receptores celulares

USP/FM/DBD-471/10 


\section{DEDICATÓRIA}


Dedico esta tese ao meu marido Eiji, e a minha filha Livia, razões do meu viver, pelo amor e apoio nas horas em que mais precisei. aos meus pais, Takeshi e Tsughi, responsáveis por minha formação acadêmica. 
AGRADECIMENTOS 


\section{AGRADECIMENTOS}

À minha orientadora Profa. Dra. Maria Notomi Sato por todas as horas dedicadas, por todos os ensinamentos, incentivo e principalmente por mais uma vez acreditar que eu seria capaz.

Ao Prof. Alberto José da Silva Duarte que me recebeu em seu laboratório e me deu a oportunidade e as ferramentas necessárias para o desenvolvimento deste trabalho.

Aos Profs. Drs. Evandro Rivitti, Celina Maruta, Érica Prearo do Ambulatório de Urticária do Departamento de Dermatologia do HC-FMUSP pela contribuição na realização deste trabalho.

Aos amigos da "Experimental": Jefferson Russo Victor, Cyro Alves de Brito, Bruno Pacola, Orlando Guerra, Elaine Cardoso, Josenilson Feitosa, Nátalli Zanete, Ana Paula de Lopes da Silva, Anna Cláudia Castelo Branco. Obrigada pela ajuda, pela amizade e pelas boas risadas que demos nos últimos anos.

Aos amigos da Urticária: Mayce Helena Azor, Juliana Cristina dos Santos, pela amizade, aprendizado, companherismo na realização dos experimentos, ao Chang Dong Kim pela ajuda com os primeiros resultados.

À Noemia Mie Orii por sua amizade, pelo auxílio na citometria de fluxo, pela ajuda com as pDCs.

À Fernanda Guedes Luiz pelo auxílio na imunoistoquímica, por me mostrar a pDC na lesão.

Aos amigos do Coração: Catarina Bueno, Meire Mari Siozak, Cláudia Finazzo, João Carlos, Luciana Bento, Vânia Andréia Gomes, pelas palavras de incentivo e pelo companheirismo. 
Aos professores da Banca do Exame de Qualificação: Dra. Mírian Nacagami Sotto, Valéria Aoki, Anderson de Sá Nunes pelas valiosas críticas e sugestões que muito contribuíram para a finalização deste trabalho.

À todos os colegas do Laboratório de Dermatologia e Imunodeficiências - Lim56 da Faculdade de Medicina da Universidade de São Paulo que de uma forma ou de outra auxiliaram na execução deste trabalho e demonstraram seu carinho nos últimos anos.

À todos os pacientes com Urticária Crônica Idiopática do Ambulatório de Dermatologia do HC-FMUSP que foram os maiores responsáveis pela realização deste trabalho.

À todos que de alguma forma contribuíram para a realização desta tese, meus sinceros agradecimentos. 
NORMALIZAÇÃO

Esta dissertação está de acordo com as seguintes normas, em vigor no momento desta publicação:

Referências: adaptado de International Committee of Medical Journals Editors (Vancouver)

Universidade de São Paulo. Faculdade de Medicina. Serviço de Biblioteca e Documentação. Guia de apresentação de dissertações, teses e monografias.

Elaborado por Anneliese Carneiro da Cunha, Maria Julia de A. L. Freddi, Maria F. Crestana, Marinalva de Souza Aragão, Suely Campos Cardoso, Valéria Vilhena. 2a ed. São Paulo: Serviço de Biblioteca e Documentação; 2005.

Abreviaturas dos títulos dos periódicos de acordo com List of Journals Indexed in Index Medicus. 
SUMÁRIO 


\section{SUMÁRIO}

\section{LISTA DE ABREVIATURAS}

LISTA DE SÍMBOLOS

LISTA DE FIGURAS

LISTA DE TABELAS

RESUMO

SUMMARY

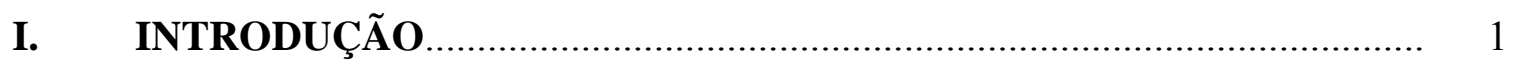

URTICÁRIA CRÔNICA IDIOPÁTICA.................................................................. 1

AGENTE IMUNOMODULADOR: OLIGODEOXINUCLEOTÍDEOS CpG............ 5

PARTICIPAÇÃO DAS CÉLULAS DENDRÍTICAS PLASMOCITOIDES NA

RESPOSTA AO OLIGODEOXINUCLEOTÍDEO CpG....................................... 9

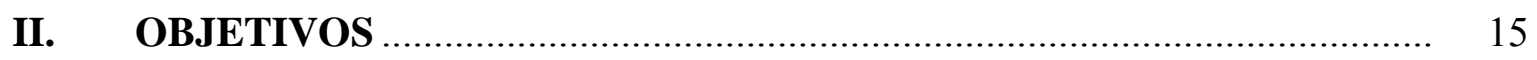

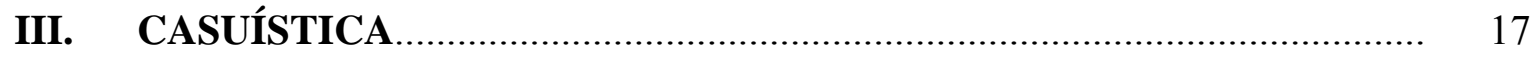

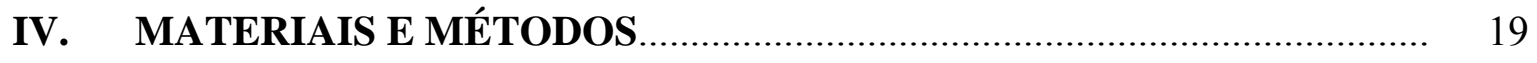

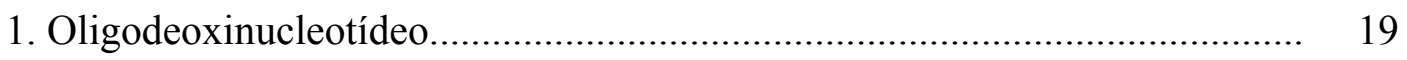

2. Indução de citocinas in vitro por oligonucleotídeos CpG............................ 19

3. Obtenção de células mononucleares $(\mathrm{CMN})$ do sangue periférico................ 20

4. Avaliação da via de sinalização para a produção de IFN- $\alpha$........................... 22

5. Caracterização e quantificação de células dendríticas plasmocitóides (pDC) em sangue periférico, análise de ativação das pDCs por estímulo com $\mathrm{CpG}$ e indução

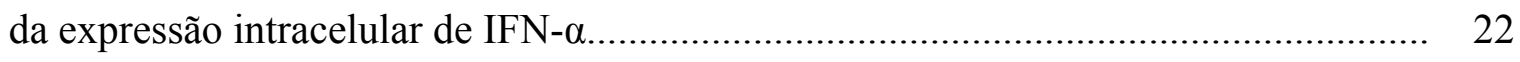

6. Ensaio imunoenzimático (ELISA) para dosagem de citocinas..................... 23

7. Reação em cadeia da polimerase em tempo real............................................ 24

8. Imunoistoquímica para a demonstração de células dendríticas plasmocitóides

CD123 positiva em biópsias de pele................................................................... 25

9. Análise estatística........................................................................ 27

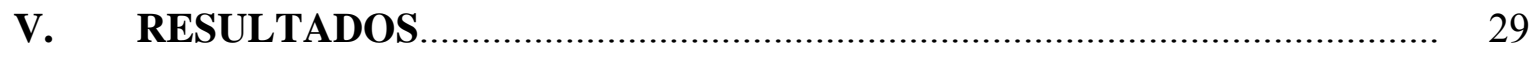


1. Características demográficas dos pacientes com Urticária

Crônica Idiopática.

2. Característica dos pacientes com Urticária Crônica Idiopática submetidos ao teste de soro autólogo.

3. Dosagem de citocinas em sobrenadantes de culturas de pacientes com UCI e controles estimuladas por oligonucleotídeos CpG.

4. Efeito modulatório do ODN-S na produção de citocinas induzidas por oligonucleotídeos CpGA

5. Análise da via de sinalização IFN- $\alpha$ em CMN após estímulo in vitro com CpGA.

6. Quantificação de pDCs em sangue periférico de indivíduos normais e pacientes com UCI

7. Análise da expressão dos marcadores de ativação/co-estimulatórias em pDCs após estímulo in vitro com CpGA.

8. Percentual de pDCs secretores de IFN- $\alpha$ após estímulo in vitro com CpGA.. 56

9. Expressão de mRNA para TLR9 e IRF-7 em pacientes UCI........................ 59

10. Expressão de CD123 (pDC) em biópsias de pele de pacientes UCI............. 61

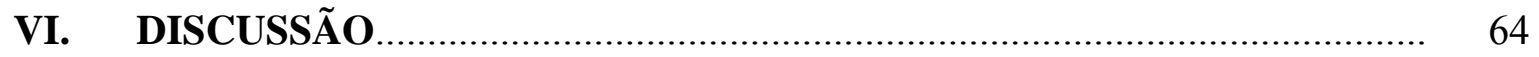

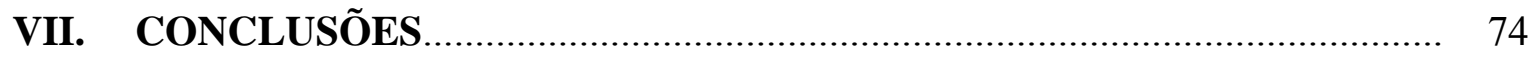

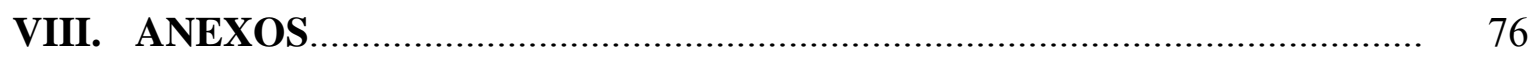

ANEXO A- Termo de consentimento livre e esclarecido.............................. 76

ANEXO B- Aprovação do Comissão de ética.................................................... 79

ANEXO C-Características individuais dos pacientes com Urticária Crônica Idiopática.......................................................................................... 80

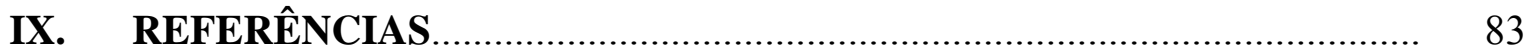




\section{LISTAS}




\section{Lista de Abreviaturas}

APC Células apresentadoras de antígeno

AP-1 Activator Protein 1

ASST Autologous serum skin test

BDCA Blood Dendritic Cell Antigen

CCL Cysteine-Cysteine Chemokine Ligand

CD Cluster of Differentiation

CMN Células mononucleares do sangue periférico

CpG Citosina Guanina ligada por uma ponte de fósforo

CXCL Cysteine-X-Cysteine Chemokine Ligand

CXCR Cysteine-X-Cysteine Chemokine Receptor

DC Célula Dendrítica

D.P. Desvio padrão

ELISA Ensaio imuno enzimático

FceRI Receptor de alta afinidade para imunoglobulina $\mathrm{E}$

GM-CFS Granulocyte-Macrophage Colony-Stimulating Factor

HMGB1 High-Mobility Group Box 1

H4 Receptor de histamina 4

HSV Herpes Simplex Virus

IFNR Interferon production regulator

IFN- $\gamma \quad$ Interferon-gama

Ig Imunoglobulina

IL Interleucina

ILT-7 Immunoglobulin-like transcripts 7

IRAK IL-1R associated kinase

IRF Interferon (IFN) regulatory factors

ISGF-3 Interferon-stimulated gene factor 3

LPS Lipopolissacáride

MAPK Mitogen Activated Protein Kinase 


$\begin{array}{ll}\text { mDC } & \text { Célula Dendrítica Mielóide } \\ \text { MHC } & \text { Complexo principal de histocompatibilidade } \\ \text { MyD88 } & \text { Myeloide differentiation primary response gene (88) } \\ \text { NC } & \text { Não consta } \\ \text { NK } & \text { Natural Killer } \\ \text { NKp44 } & \text { Natural Killer 44-kD surface molecule } \\ \text { NFkB } & \text { Nuclear Factor Kappa B } \\ \text { ODN } & \text { Oligodeoxinucleotídeo } \\ \text { PAMPS } & \text { Padrões Moleculares Associados aos Patógenos } \\ \text { pDC } & \text { Célula Dendrítica Plasmocitóide } \\ \text { PHA } & \text { Fitohemaglutinina } \\ \text { SDF-1 } & \text { Stromal Cell Derived Factor-1 } \\ \text { SHIP } & \text { Src-homology 2 contendo 5' inositol fosfatase } \\ \text { SLE } & \text { Lupus Eritematoso Sistêmico } \\ \text { STAT } & \text { Signal transducer and activator of transcription } \\ \text { Syc } & \text { Spleen tyrosine kinase } \\ \text { t-bet } & \text { T-box family of transcription factors } \\ \text { Th } & \text { Células T auxiliares } \\ \text { TLR } & \text { Toll-Like Receptor } \\ \text { TNF- } \alpha & \text { Fator de necrose tumoral-alfa } \\ \text { TRAF } & \text { TNF receptor-associated factors } \\ \text { UC } & \text { Urticária Crônica } \\ \text { UCI } & \text { Urticária Crônica idiopática } \\ & \end{array}$




\section{Lista de Símbolos}

$\begin{array}{ll}\mu \mathrm{g} & \text { Micrograma } \\ \mu \mathrm{M} & \text { Micromolar } \\ \mathrm{mL} & \text { Mililitro } \\ \mathrm{ng} & \text { Nanograma } \\ \mathrm{pg} & \text { Picograma } \\ \mathrm{rpm} & \text { Rotações por minuto } \\ \pm & \text { Mais ou menos } \\ \Delta & \text { Delta } \\ < & \text { Menor } \\ = & \text { Igual } \\ { }^{\circ} \mathrm{C} & \text { Graus Celsius }\end{array}$




\section{Lista de Figuras}

Página

Figura 1 CpG-DNA, reconhecimento via TLR-9.

Figura 2 Produção de IFN- $\alpha$ por pDCs em resposta ao CpG.

Figura 3 Dosagem de IL-10 e IFN- $\alpha$ em sobrenadantes de culturas de leucócitos de pacientes com UCI estimulados por CpGA.

Figura 4 Dosagem de IL-10 e IFN- $\alpha$ em sobrenadantes de culturas de leucócitos de pacientes com UCI estimulados por CpGA.

Figura 5 Dosagem de IL-12p40 em sobrenadantes de culturas de leucócitos de pacientes com UCI estimulados por ODN-S

Figura 6 Efeito modulatório do ODN-S na produção de IL-10 em sobrenadantes de culturas de leucócitos estimulados por CpGA

Figura 7 Efeito modulatório do ODN-S na produção de IL-10 em sobrenadantes de culturas de leucócitos estimulados por CpGA

Figura 8 Efeito modulatório do ODN-S na produção de IFN- $\alpha$ de leucócitos de pacientes com UCI estimulados por CpGA

Figura 9 Histograma ilustrativo da expressão intracelular de STAT1 e STAT4 em células mononucleares após estímulo in vitro com CpGA.

Figura 10 Expressão intracelular de STAT1 em CMN após estímulo in vitro com CpGA.

Figura 11 Expressão intracelular de STAT1 em CMN após estímulo in vitro com CpGA.

Figura 12 Expressão intracelular de STAT4 em CMN após estímulo in vitro com CpGA.

Figura 13 Expressão intracelular de STAT4 em CMN após estímulo in vitro com 46 
CpGA.

Figura 14 Expressão intracelular de STAT1 e STAT4 em CMN após estímulo in vitro com CpGA.

Figura 15 Quantificação de pDCs em sangue periférico de pacientes com Urticária Crônica Idiopática.

Figura 16 Histograma ilustrativo da expressão das moléculas CD40, CD80 e CD86 em pDC após estímulo in vitro com CpGA

Figura 17 Expressão das moléculas CD40, CD80 e CD86 em pDCs após estímulo in vitro com CpGA

Figura 18 Expressão das moléculas CD40, CD80 e CD86 em pDCs após estímulo in vitro com CpGA

Figura 19 Expressão das moléculas CD40, CD80 e CD86 em pDCs após estímulo in vitro com CpGA

Figura 20 Histograma ilustrativo da expressão intracelular de IFN $\alpha$ em pDC após estímulo in vitro com CpGA.

Figura 21 Expressão intracelular de IFN- $\alpha$ pDCs após estímulo in vitro com CpGA

Figura 22 Efeito do CpGA na expressão relativa de mRNA de TLR9 e IFR-7.

Figura 23 Células dendríticas plasmocitóides em lesões de pele na UCI. 


\section{Lista de Tabelas}

Página

Tabela I Característica demográfica dos pacientes com Urticária Crônica Idiopática.

Tabela II Característica dos pacientes com Urticária Crônica Idiopática submetidos ao teste de soro autólogo. 


\section{RESUMO}


Taniguchi, EAF. Caracterização fenotípica e grau de ativação de células dendríticas plasmocitóides ao estímulo in vitro com oligodeoxinucleotídeos CpG na Urticária Crônica. [tese]. São Paulo: "Faculdade de Medicina, Universidade de São Paulo"; 2010.91p.

INTRODUÇÃO: A urticária crônica é caracterizada pelo aparecimento de placas eritêmato-edematosas, pruriginosas que perduram por mais de seis semanas. A investigação da imunidade inata é de grande importância para a compreensão da imunopatologia de doenças dermatológicas crônicas como a Urticária Crônica Idiopática (UCI). Entre os componentes da resposta inata, a avaliação das células dendríticas plasmocitóides (pDCs) e sua capacidade de ativação por agonistas de Toll Like receptor 9 (TLR9) pode contribuir para avaliar o desequilíbrio imunológico encontrado na UCI. OBJETIVOS: Investigar a imunidade inata em pacientes com UCI e os mecanismos envolvidos na modulação da produção de IFN- $\alpha$ por pDCs induzida pela ativação do TLR9. MÉTODOS: A secreção de IFN- $\alpha$ e IL-10 por leucócitos de pacientes UCI $(n=26)$ e indivíduos normais $(\mathrm{Co}, \mathrm{n}=50)$ induzida pelo agonista de TLR9, CpGA $(1.0$ e $2.0 \mu \mathrm{M})$, ou IL12p40 induzida pelo ODN inibitório (ODN S) foi realizado por ensaio imunoenzimático. Quantificação de pDCs em sangue periférico, expressão de moléculas coestimulatórias, expressão intracelular de IFN- $\alpha$ por pDCs e fosforilação de STAT (1 e 4) foram analisados por citometria de fluxo. Expressão do mRNA de TLR9 e fator regulador de interferon-7 foi realizado por real time PCR. A presença da pDC (CD123+) em lesões de pele de pacientes UCI foi avaliada por imunoistoquímica. RESULTADOS: Os resultados mostraram uma diminuição na produção de IFN- $\alpha$ e IL-10 por leucócitos de pacientes UCI após estímulo com CpGA. O estímulo com ODN S induziu a produção de IL12p40 e suprimiu ainda mais a produção de IL-10 e IFN- $\alpha$ induzida pelo CpGA, até $98 \%$ de inibição. O número de pDCs no sangue periférico e a capacidade de ativação da $\mathrm{pDC}$ nos pacientes, avaliada pela expressão de moléculas co-estimuladoras foi semelhante aos indivíduos normais. Além disto, foram detectadas raras pDCs nas lesões de pele dos pacientes. Um aumento constitutivo da fosforilação de STAT1 foi detectado em linfócitos não estimulados de pacientes UCI associado a uma diminuição da expressão de mRNA de TLR9 após estímulo com CpGA e alterada expressão de mRNA de IRF-7, que podem contribuir para a baixa produção de IFN- $\alpha$. CONCLUSÃO: Os achados mostram uma inibição na produção de IFN- $\alpha$ via TLR9, tendo como alvo a pDC e sua participação na resposta inata na Urticária Crônica.

Descritores: 1. Urticaria Crônica Idiopática, 2. Imunidade Inata, 3. Interferon alfa, 4. Receptores celulares 
SUMMARY

$\longrightarrow$ 
Taniguchi, EAF. Phenotypic characterization and degree of activation of plasmacytoid dendritic cells induced by oligodeoxynucleotides CpG in Chronic Idiopathic Urticaria [thesis]. São Paulo: “Faculdade de Medicina, Universidade de São Paulo”; 2010.91p.

INTRODUCTION: Chronic urticaria is a skin disorder characterized by recurrent and transitory itchy weals occurring regularly more than 6 weeks. The investigation of the innate immunity is an important parameter to understand the immunopathology of chronic dermatological diseases, such as Chronic Idiopathic Urticaria (CIU). Among the innate immune components, such as plasmacytoid dendritic cells (pDC) and their functional study activation thorough TLR-9 ligand could contribute to evaluate the immunologic disequilibrium founded in the CIU. OBJECTIVES: We decided to investigate innate immunity in CIU and the mechanisms implicated in the modulation of IFN- $\alpha$ production by pDCs upon TLR9 activation. METHODS: The secretion of IFN- $\alpha$ and IL-10 secretion by leucocytes of patients with CIU $(n=26)$ and healthy control $(\mathrm{HC}, \mathrm{n}=50)$ induced by TLR9 ligand, CpG type A $(1.0$ and $2.0 \mu \mathrm{M})$, or IL12p40 secretion induced by inhibitory ODN (ODN S) was assessed by enzyme-linked immunosorbent assay. Enumeration of pDC, coestimulatory molecules expression, intracellular IFN- $\alpha$ expression, and STAT (1 and 4) phosphorylation were assessed by flow cytometry. TLR9 and interferon regulatory factor-7 mRNA transcripts were evaluated by real-time PCR. The presence of pDCs $(\mathrm{CD} 123+)$ in the skin lesion of patients with CIU were assessed by means of immunohistochemistry staining. RESULTS: The findings showed a decreased IFN- $\alpha$ and IL-10 secretion by leucocytes of CIU patients induced by CpGA. Inhibitory ODN was able to induce IL12p40 and further inhibited the IFN- $\alpha$ secretion in both HC and patients achieving up 98\% inhibition. A normal pDC percentage and degree of activation by costimulatory molecules expression was observed in CIU in patients was similar to control group. Moreover, rare presence of pDCs was detected in the skin lesion of patients. An increased constitutive STAT1 phosphorylation on non-stimulated lymphocytes and CpGA activation induced a down-regulation of TLR9 mRNA transcripts associated with altered IRF-7 along the time of $\mathrm{CpG}$ activation which may contribute to the decreased IFN$\alpha$ secretion. CONCLUSIONS: Altogether, the findings showed an impaired IFN- $\alpha$ secretion via TLR-9, implicating innate immunity through pDCs as target in Chronic Urticaria.

Descritores: 1. Chronic Idiopathic Urticaria, 2. Innate Immunity, 3. Alpha Interferon, 4. Celular receptors 


\section{INTRODUÇÃO}




\section{INTRODUÇÃO}

\section{URTICÁRIA CRÔNICA IDIOPÁTICA}

A urticária é uma das afecções dermatológicas mais comuns, que afeta cerca de $15-25 \%$ da população. É caracterizada pelo aparecimento de lesões/urtica, evanescentes, que cursam com ou sem angioedema. Estes sinais clínicos são acompanhados de prurido que piora a noite, que geralmente desaparecem em 24 horas. A urticária é classificada de acordo com a duração do quadro, considerada aguda quando os sintomas perduram menos que 6 semanas, crônica quando a duração dos sintomas é maior que 6 semanas e episódica quando a afecção acomete intermitentemente.

A urticária crônica acomete aproximadamente $0,1 \%$ da população, e é capaz de reduzir significativamente a qualidade de vida dos pacientes (O'Donnel et al., 1997, Sabroe et al., 1999). É gerada pela desgranulação cutânea de mastócitos e/ou basófilos que liberam potentes mediadores vasoativos que causam aumento da permeabilidade capilar de pequenas veias resultando na formação de pápulas (Ring et al., 1999). O prurido e a dor são conseqüências da estimulação dos nervos sensoriais. A desgranulação das células inflamatórias é atribuída à causa imunológica (auto-imune, IgE, imunocomplexo, complemento), não imunológica (pseudoalérgenos como medicamentos) e idiopática (Hein, 2002).

Na UC há evidências de que $45 \%$ dos pacientes apresentam etiologia autoimune e cerca de 55\% permanecem com etiologia desconhecida e são considerados idiopáticos (UCI). Cerca de 35 a $40 \%$ dos pacientes apresentam autoanticorpos contra a cadeia $\alpha$ do receptor de alta afinidade para $\operatorname{IgE}(\mathrm{FccR} \mathrm{R})$, enquanto que 5 a $10 \%$ apresentam $\operatorname{IgG}$ anti- 
IgE capaz de promover a liberação de histamina de mastócitos e basófilos (Kaplan \& Greaves, 2009)

O teste cutâneo realizado com o soro autólogo, denominado teste intradérmico de soro autólogo (ASST, autologous serum skin test) evidencia a presença dos autoanticorpos anti-FceRI e/ou anti-IgE pela desgranulação de mastócitos da pele e formação de pápulas. Este teste tem sido recomendado como triagem nos casos suspeitos de UC (Sabroe et al., 1999) e possui sensibilidade e especificidade de 65 a $81 \%$ e 71 a $78 \%$, respectivamente (Greaves, 2003).

O ensaio de liberação de histamina é considerado teste padrão de laboratório para o diagnóstico e avaliação de UC de origem auto-imune. Há uma correlação positiva dos pacientes com ASST positivo que apresentam o teste in vitro de liberação de histamina positivo, enquanto que não há liberação de histamina em pacientes com ASST negativo (Niimi et al., 1996).

$\mathrm{Na} \mathrm{UC}$, outros autoanticorpos podem ser detectáveis, tais como os reativos a tecidos tireoidianos, o que sugere associação desta patologia com a doença auto-imune da tireóide (Dreskin e Andrews, 2005). A prevalência de autoanticorpos anti-tireóide na UC tem sido estimada como 12 a 29\% (Doutre et al., 2006). Além disto, a evidência de doença auto-imune da tireóide e função anormal tireoideana é mais encontrada em pacientes com teste de soro autólogo positivo, o que corrobora com a teoria da etiologia auto-imune da UC. Entretanto, estes autoanticorpos anti-tireóide não parecem ser os agentes causadores diretos da UC. Altos títulos de anticorpos anti-nuclear foram observados em 2\% de crianças (4-15 anos) com UC. Não foi observada a presença de anticorpos anti-tireoglobulina e anti-microssomal e o ASST foi positivo em $38 \%$ dos casos (Jirapongsananuruk et al., 2009). 
Recentes estudos têm como foco diagnóstico e tratamento na UCI (Kaplan, 2007) assim como a compreensão do papel dos basófilos e mastócitos e de fatores da coagulação na patogenia da doença (Saini, 2009).

Os basófilos têm sido frequentemente implicados no desenvolvimento da UCI (Eckman et al., 2008). A basopenia encontrada em pacientes com UCI é inversamente relacionada à gravidade da doença (Gratan et al., 2003). Uma das possíveis explicações seria o recrutamento dos basófilos para a pele (Caproni et al., 2005) visto que, basófilos são encontrados em biópsias de pele, lesionada ou não, de pacientes com UCI. Outra possibilidade seria a desgranulação destes basófilos por fatores circulantes presentes no soro de pacientes com UCI, capazes de ativar basófilos e mastócitos. Neste contexto, moléculas de ativação presentes na superfície de basófilos servem como marcadores capazes de avaliar o grau de ativação celular em indivíduos atópicos e pacientes com UCI. Foi demonstrado que os marcadores de ativação e desgranulação como CD63 e CD203c estão aumentados nos basófilos de pacientes com UCI, e que são hiperreativos à IL-3, na resposta ao anticorpos anti-IgE (Lourenço et al., 2008). Outros estudos demonstraram uma alterada expressão de moléculas envolvidas na liberação de histamina após sinalização via FceRI (spleen tyrosine kinase - Syc) ou das moléculas SHIP1 e SHIP2 (Src-homology 2 contendo 5' inositol fosfatase) envolvidas na inibição da ativação (Macglashan, 2007). Uma diminuição dos níveis da proteína SHIP1 foi observada em pacientes com UC respondedores ao estímulo com anti-IgE enquanto que aumento na liberação de histamina em pacientes não respondedores correlacionou com aumento dos níveis de SHIP1 e SHIP2 (Vonakis et al., 2007).

Recentemente, estudos verificaram o envolvimento de fatores da cascata de coagulação e fibrinólise no resultado do teste de soro autólogo (ASST). O soro autólogo de pacientes com UCI quando injetado intradermicamente é capaz de induzir a liberação 
de histamina mesmo quando há depleção de $\operatorname{IgG}$, o que sugere que outros fatores circulantes, além de autoanticorpos contra o FcєRI ou a IgE podem estar envolvidos na patogenia da doença (Asero et al., 2007). Takahagi e colaboradores (2009) demonstraram correlação positiva entre produtos de degradação da fibrina, d-dímero e proteína $\mathrm{C}$ reativa em pacientes com $\mathrm{UC}$.

O perfil de produção de citocinas na UC, em pacientes com ou sem autoanticorpos anti-FcعRI, não são conclusivos, mas indicam um desequilíbrio na produção de citocinas. Produção diminuída de IL-2, IFN- $\gamma$ e de IL-4 pelas células mononucleares estimuladas com PHA, principalmente no grupo ASST positivo, foi descrito, sugerindo modulação negativa das células Th1/Th2 na UC (Confino-Cohen et al., 2004). Significativa diminuição na produção de IL-12 e IFN- $\gamma$ foi detectada em pacientes com UC, mesmo quando sub-divididos quanto ao ASST (Piconi et al., 2002). Em paralelo, há aumento na produção de IL-10 e TNF- $\alpha$ em resposta a mitógenos como a fitohemaglutinina e lipopolissacáride nos pacientes com UC em relação ao grupo controle (Piconi et al., 2002). Nossos resultados prévios, mostraram que na UCI, há um aumento dos níveis circulantes de citocinas pró-inflamatórias como TNF- $\alpha$, IL-10, IL12p70, e IL-6 associados a um desequilíbrio na produção de citocinas induzidas pela PHA, como a IL-2, IL-17a e IL-10 (Dos Santos et al., 2008). Alterações estas observadas, independente do ASST, ou seja, acometendo a maioria dos pacientes com UCI. Estes dados salientam o conceito de desequilíbrio da produção de citocinas na UCI, possivelmente decorrente de alterações na produção de citocinas com potencial regulatório.

A compreensão do papel desempenhado por diversos tipos celulares, o envolvimento dos fatores da coagulação e das citocinas na doença pode contribuir ao estudo da imunopatogênese da UC. Desta forma, o estudo in vitro de agentes 
imunomoduladores capazes de interferir na ativação das células envolvidas na resposta imune inata, e na produção de citocinas pode trazer perspectivas para o estudo de doenças de caráter inflamatório crônico, como estratégia de imunomodulação, seja ativando ou inibindo o excesso de ativação imunológica.

\section{AGENTE IMUNOMODULADOR: OLIGODEOXINUCLEOTÍDEOS CpG}

Agentes imunomodulatórios, têm sido utilizados como adjuvantes vacinais ou para estimular a capacidade da resposta imune adaptiva por ativar os componentes de resposta inata. Estes agentes incluem uma nova classe denominados de CpG DNA freqüentemente estudados na forma de oligodeoxinucleotídeos (ODN) sintéticos (ODN CpG). O CpG contém uma seqüência específica composta de um dinucleotídeo citosina-guanina ( $\mathrm{CG}$ ) ligada através de uma ponte de fósforo $(\mathrm{CpG})$, que ativa diretamente monócitos, macrófagos e células dendríticas a produzirem citocinas e quimiocinas e são considerados potentes indutores de resposta Th1. Diferentes tipos de CpG vêm sendo estudados, podendo exercer atividades estimulatórias ou inibitórias no sistema imunológico. Estudos experimentais vêm demonstrando uma ampla atividade imunomodulatória do $\mathrm{CpG}$ em tumores, em processos infecciosos e na alergia, trazendo perspectivas de aplicações terapêuticas (Krieg et al., 2002).

Estas sequências de DNA bacteriano, são reconhecidas por receptor específico para o CpG denominado Toll-Like 9 (TLR9). São pertencentes à uma família de 11 receptores que medeiam o reconhecimento de padrões moleculares associados aos patógenos (PAMPS) (Janeway et al., 2002). O CpG, está presente no DNA de bactérias, vírus e retrovírus na forma não metilada em proporção vinte vezes maior do que nos vertebrados. A ativação do TLR-9 induz uma cascata de sinalização que envolve as 
moléculas MyD88, IRAK, TRAF-6 e resulta na ativação de MAP quinases e NFkB (Bauer S \& Wagner H, 2002).

Os ODN-CpG sintéticos são classificados com base em suas ações modulatórias em três diferentes classes: o CpG A, que induz a secreção de IFN- $\alpha$ pelas pDCs, o CpG B que possui capacidade estimulatória em células $\mathrm{B}$ e o $\mathrm{CpG} \mathrm{C}$ que combina ambos os CpGs A e B (Hartmann et al., 2003).

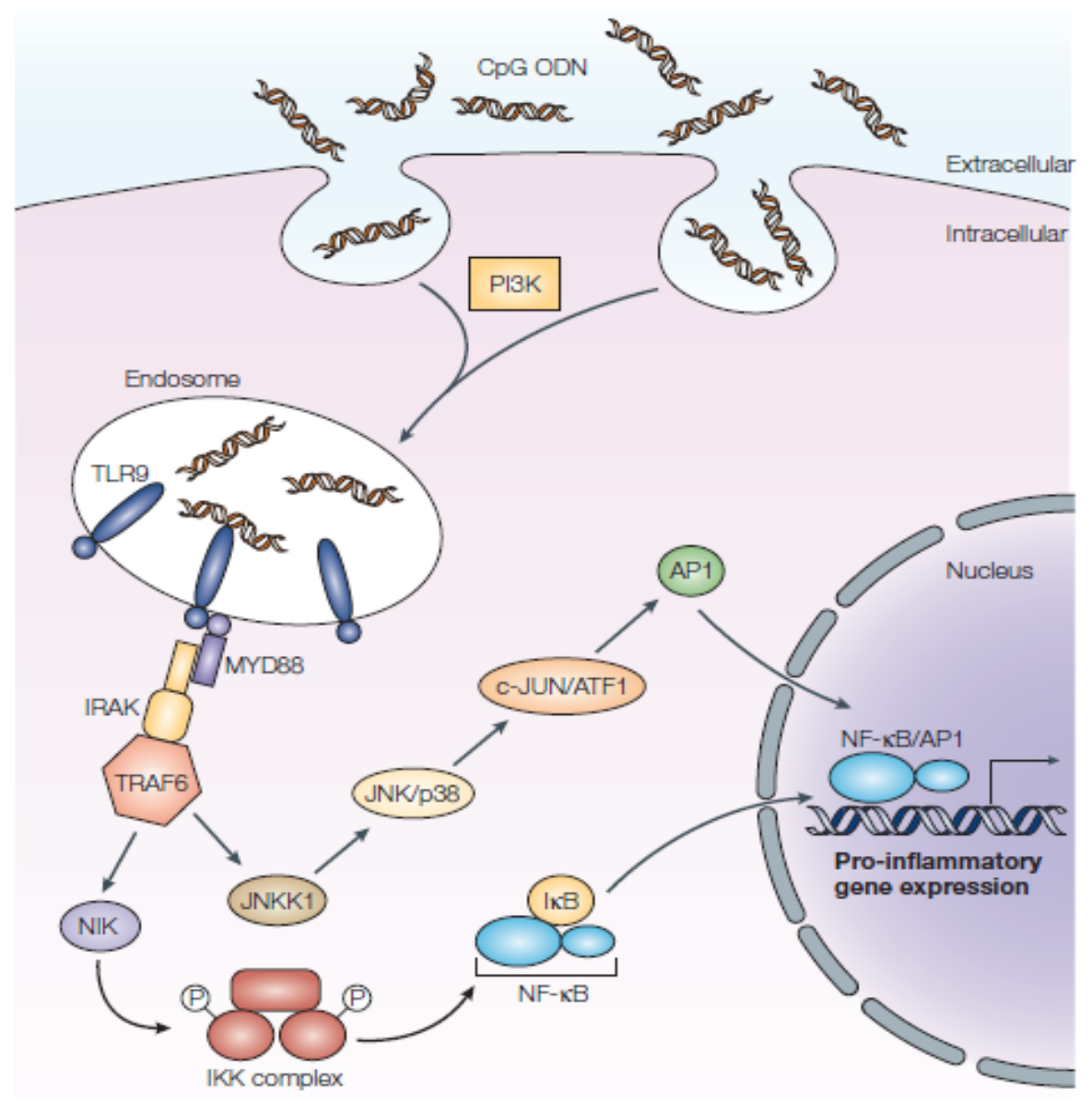

Figura 1: CpG-DNA, reconhecimento via TLR-9 (Klinman, 2004) 
O estímulo com ODN CpGA (2216) induz a produção de altas concentrações de IFN- $\alpha$ pela pDC e aumento da expressão das moléculas co-estimulatórias CD80 e CD86 e de moléculas de classe II do MHC e não exercem efeito sobre as células B (Kerkmann et al., 2003). Por outro lado, o estímulo com CpGB (2006) ativa as células B resultando no aumento de expressão de moléculas de classe II do MHC e co-estimulatórias e induz a secreção de IL-8 e TNF- $\alpha$ (Hemmi et al., 2003). A produção de IFN- $\alpha$ induzida pelo CpGA pode ser controlada por um mecanismo de feedback positivo que envolve a sinalização via receptor de IFN- $\alpha \beta$ (IFN- $\alpha \beta R$ ), com conseqüente recrutamento, fosforilação e heterodimerização de STAT1 e STAT2 que se associa ao IRF9 para formar o complexo STAT1/2:IRF9 também chamado ISGF3. O ISGF3 é translocado para o núcleo e induz a transcrição de muitos genes, amplificando a produção de IFN$\alpha \beta$ (Platanias et al., 2005). A família STAT compreende sete fatores de transcrição: STAT1, STAT2, STAT3, STAT4, STAT5A, STAT5B e STAT6. O STAT1 foi inicialmente identificado como mediador da resposta celular para IFN- $\alpha$ e posteriormente passou a ser conhecido como o maior componente para a resposta para IFN- $\gamma$ (Najjar I. et al., 2010). O STAT4 não é normalmente considerado como um fator envolvido na via de sinalização para Intérferons do tipo I. Possui papel importante no crescimento e diferenciação de células Th1, sendo recrutado e fosforilado após estímulo com IL-12. Induz citocinas como IFN- $\gamma$ e TNF- $\alpha$ e é ativado após a ligação de intérferons do tipo 1 com IFNR. Desta forma é capaz de fazer uma interligação entre as vias de sinalização dos intérferons do tipo I e II (Gestermann et al., 2010).

O efeito do $\mathrm{CpG}$ sobre o sistema imune não necessariamente precisa ser estimulatório, algumas seqüências de oligonucleotídeos podem ser usadas para inibir as respostas imunes (Krieg et al., 1998). Várias seqüências de DNA inibitórios têm sido avaliadas quanto a sua especificidade, vias de sinalização e mecanismos de supressão da 
ativação via TLR9 (Ashman et al., 2004). Os oligonucleotídeos 2114 (TCCTGGAGGGGAAGT) e 2088 (TCCTGGCGGGGAAGT) foram identificados como potentes inibidores da sinalização induzida pela interação com o TLR9 em camundongos (Stunz et al., 2002). Em camundongos, ODNs inibitórios são capazes de bloquear as vias de sinalização de NFkB, MAPK e NF-IL-6 (Ashman et al., 2004). A produção de IFN- $\alpha$ pode ser inibida in vitro por antagonistas como o ODN TTAGGGG (Gursel et al., 2003) ou por inibidores da acidificação endossomal como a cloroquina (Macfarlane e Manzel 1998).

Recentemente foi proposto que os ODNs inibitórios podem ser divididos em quatro grupos que variam de acordo com sua especificidade pelo TLR9, competição pela captura celular pelo ODN, capacidade de ligação ao TLR9 e efetivação da ativação (Trieu et al., 2006). Em modelo experimental de encéfalomielite auto-imune a utilização de uma seqüência de oligonucleotídeos imunomodulatória foi capaz de inibir a ativação de células Th1 associadas ao distúrbio auto-imune, suprimindo a gravidade da doença (Ho et al., 2003).

Em humanos, os CpGs têm sido utilizados sozinhos ou em combinação com vacinas, anticorpos ou alérgenos em estudos clínicos explorando sua capacidade imunomodulatória (Klinman, 2004), com grande potencial para a utilização no tratamento de desordens auto-imunes (Lenert, 2005). Os CpGs são capazes de inibir a ativação via TLR-9 por um mecanismo até agora desconhecido. Foi demonstrado que os CpGs imunomodulatórios podem afetar a ativação das células Th1 através da inibição de STAT1, 3 e 4 (Shirota et al., 2004), além de inibir a proliferação e secreção de IL-6 por linfócitos B e bloquear a produção de IFN- $\alpha$ e IL-12 por pDCs estimuladas por CpGs estimulatórios (CpG A, B e C) (Duramad et al., 2005). 
Até o momento não há descrição de estudos que relatam o uso de $\mathrm{CpG}$ in vitro seja de potencial inibitório ou estimulatório na resposta imune na UC, este fato seria interessante considerando o conceito de distúrbio imunológico descrito na UC.

\section{PARTICIPAÇÃO DAS CÉLULAS DENDRÍTICAS PLASMOCITÓIDES NA RESPOSTA AO OLIGODEOXINUCLEOTÍDEO CpG}

$\mathrm{O}$ uso de oligonucleotídeos sintéticos contendo motivos $\mathrm{CpG}$ que mimetizam o DNA bacteriano, evita o uso de bactérias inativadas ou produtos do mesmo, permitindo sua utilização como adjuvante vacinal (revisto por Krieg, 2002). O CpG atua direta ou indiretamente em várias populações celulares, e são considerados potentes indutores de ativação de APCs. As DCs são APCs profissionais e exercem um papel central na iniciação da resposta imune aos antígenos, estimulando tanto as células CD4+ e CD8+ naive. As DCs imaturas após a estimulação com lipopolissacarídeos, citocinas ou outros estímulos aumentam a expressão de moléculas de MHC-II e de moléculas coestimulatórias, tornam-se células maduras capazes de apresentar Ags e ativar os linfócitos T com extraordinária eficiência.

Populações distintas de DCs imaturas podem ser caracterizadas como mielóide ou linfóide, de acordo com a sua origem. As células dendríticas mielóides (mDC) têm o fenótipo CD11c+/CD123-, secretam IL-12 e uma grande variedade de citocinas e quimiocinas em resposta aos PAMPs (Banchereau e Steinman, 1998). Estas células são semelhantes às DCs derivadas de monócitos, que são geradas in vitro após estímulo dos monócitos com GM-CFS e IL-4 (Sallusto e Lanzavecchia, 1994). Outra população de DCs são chamadas de células dendríticas plasmocitóides e foram inicialmente caracterizadas como uma população imatura, CD11c-, chamadas de pré-pDCs (precursoras das pDCs). Esta população é distinta das mDCs $\mathrm{CD} 11 \mathrm{c}+$, possuem o 
fenótipo CD11c-/CD123+/CD303+(BDCA2)/CD304+(BDCA4) e correspondem quantitativamente à $1,4 \%$ das células mononucleares do sangue periférico (Sandberg et al., 1991). Os marcadores BDCA-2 e BDCA-4 são restritos às pDCs humanas no sangue periférico e medula óssea (Dzionek et al., 2001).

As pDCs são conhecidas por sua extraordinária capacidade de produzir altos níveis de IFN- $\alpha$ em resposta à DNA e RNA viral tão bem como aos agonistas sintéticos de TLR9 e 7. Têm sido descrito que $60 \%$ dos genes necessários para a síntese de IFNs do tipo I e III são expressos por pDCs ativadas (Ito et al., 2006). Além de grandes produtoras de IFN- $\alpha$ (3-10 pg/célula em resposta à um potente estímulo como HSV-1), pDCs também produzem IFN- $\beta$ (em menor quantidade), tão bem como outros tipos de IFNs do tipo I que sinalizam através do mesmo receptor IFN $\alpha / \beta$, incluindo IFN- $\kappa$ e IFN- $\omega$ (Ito et al., 2006; Izaguirre et al., 2003).

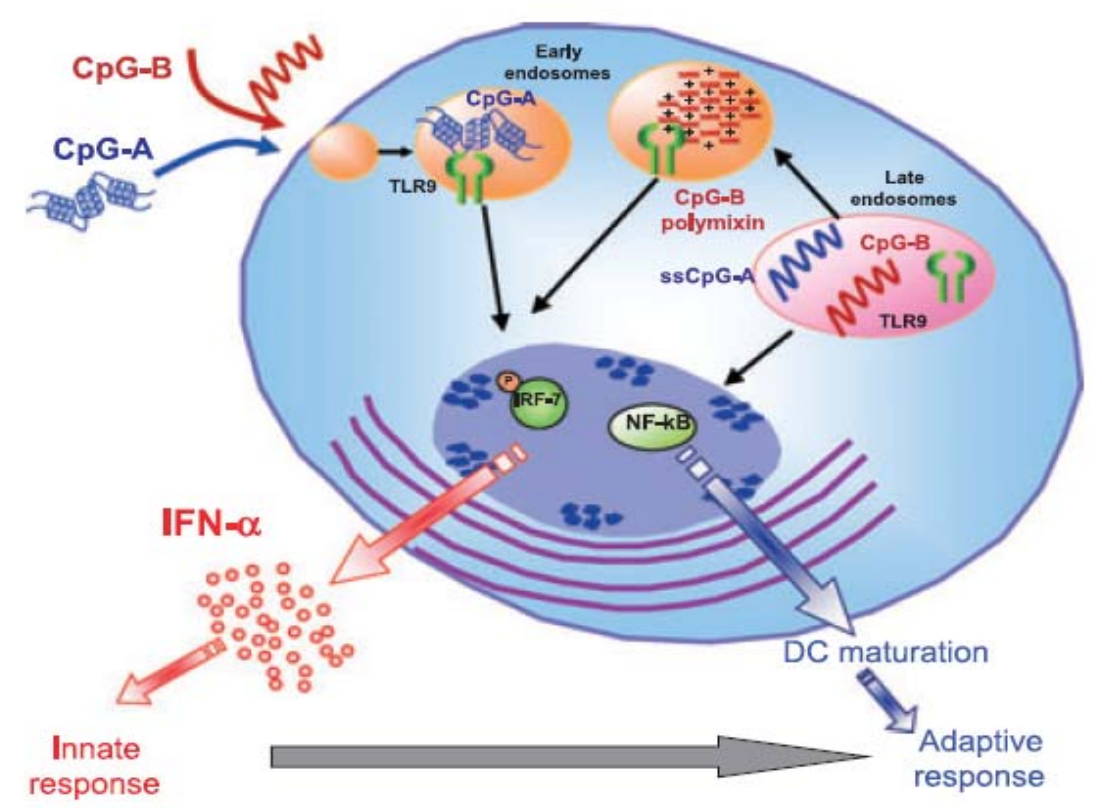

Figura 2: Produção de IFN- $\alpha$ por pDCs em resposta ao CpG (Guiducci, 2008). 
As pDCs também podem produzir citocinas pró-inflamatórias como TNF- $\alpha$ e IL-6 em infecções virais. O TNF- $\alpha$ é responsável em parte, pela maturação da pDC (Jego et al., 2003). Quimiocinas como CCL2, CCL3, CCL5, CXCL10 e IL-8, que são predominantemente do tipo $\mathrm{CXCR} 3$, podem ser produzidas em resposta à vírus e são capazes de recrutar células NK e células T ativadas (Megjugorac et al., 2004; BendrissVermare et al., 2005). Em adição, as pDCs expressam CXCR3, CXCR4 e CCR5 e são capazes de migrar em resposta à SDF1 e outras quimiocinas (Vanbervliet et al., 2003).

As pDCs podem ser ativadas por vírus e bactérias, através de mecanismos do sistema imune inato que envolvem os TLR. Em humanos as pDCs expressam TLR7 e TLR9, presentes em vesículas intracelulares (Hemmi et al., 2002; Krug et al., 2001) e a exposição aos agonistas sintéticos de TLR7 (componentes de imidazoquinoline ou análogos da guanosine) e TLR9 (CpG), induz a secreção de IFN- $\alpha$ e citocinas próinflamatórias (Tilton et al., 2008). Além disto, induz maturação e diferenciação celular, e aumento de moléculas coestimulatórias como CD80, CD86 e CD40 (Akira, 2001). Visto que os receptores TLR7 e TLR9 estão presentes em compartimentos endossomais, as pDCs possuem receptores capazes de internalizar vírus e DNA bacteriano. Fazem parte deste grupo de receptores as lectinas do tipo $\mathrm{C}$ como o BDCA-2 e o receptor de manose, sendo que o bloqueio destes receptores por anticorpos é capaz de prevenir a produção de IFN- $\alpha$ pelas pDCs (Dzionek et al., 2001; Fanning et al., 2006). Em adição às lectinas do tipo $\mathrm{C}$, vírus opsonizados e imunocomplexos contendo DNA ou RNA (como ocorre no Lúpus) podem entrar na pDC através da interação com o FcyRII (CD32), que estimula a produção de IFN- $\alpha$ através do TLR9 e 7 contribuindo para a ativação autoimune (Bave et al., 2003). Foi demonstrado que a proteína HMGB1 (highmobility group box 1), liberada por células necróticas, ligada ao CpGA resultou em aumento de IFN- $\alpha$ via TLR9. A HMGB1 também pode ser liberada pela pDC após 
estímulo com $\mathrm{CpG}$, regulando a produção de IFN- $\alpha$ e maturação da $\mathrm{pDC}$ de forma autócrina (Dumitriu et al., 2005).

Nos compartimentos endossomais ocorre o reconhecimento do DNA e RNA (viral ou bacteriano) pelos TLR 7 ou 9 que são expressos constitutivamente em altos níveis em pDCs murinas e humanas (Kadowaki et al., 2001). Entretanto, a expressão de TLR9 não é o suficiente para explicar os altos níveis de IFN- $\alpha$ produzidos pelas pDCs. Honda e colaboradores (2005) sugerem que a habilidade da pDC de reter o CpG por mais tempo no compartimento endossomal, a diferencia dos outros tipos celulares.

A produção de IFN- $\alpha$ induzida pelo CpGA depende do mecanismo de sinalização que conecta TLR-MyD88, sendo que os fatores regulatórios de intérferons (IRF) têm um papel importante na regulação da transcrição dos genes de IFN- $\alpha$ e IFN$\beta$. As pDCs expressam constitutivamente a maioria dos genes de IRFs e altas concentrações de mRNA para IRF5 e IRF7, responsáveis pela rápida síntese de IFN- $\alpha$ (Kerkmann et al., 2003; Takauji et al., 2002). Assim, o fator MyD88 recruta a molécula

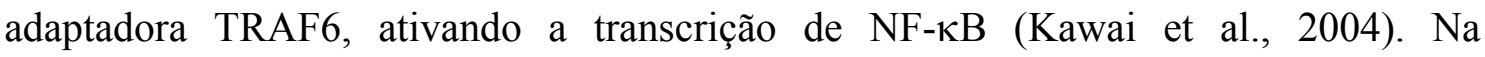
sinalização via TLR7/9 é essencial a participação do IRF-5 e IRF7, embora tenha sido observado que camundongos deficientes de IRF5 produziram quantidades normais de IFN- $\alpha$ após estímulo com CpGA enquanto que o IRF7 foi totalmente necessário para a produção de IFN- $\alpha$ pela pDC (Takaoka et al., 2005).

Uma vez ativadas pelos ligantes TLR 7/9 as pDCs aumentam a expressão de moléculas coestimulatórias bem como moléculas de MHC classe I e II. Após maturação as pDCs perdem a capacidade de produzir IFN- $\alpha$ e ganham a capacidade de apresentar antígenos. Enquanto que a maior parte dos estudos mostram que as $\mathrm{mDC}$ são melhores apresentadoras de antígenos que as pDCs, outros estudos têm demonstrado a habilidade da pDC como APC para as células T CD4+ e TCD8+ (Lui et al., 2009). As pDCs 
estimuladas por CpGA ou CpGB foram capazes de ativar células TCD8+ de memória enquanto que o CpGB foi mais eficiente que o CpGA na capacidade de ativar células $\mathrm{T}$ CD8 naives (Rothenfusser et al., 2004).

Na UC, doença que leva a liberação de mediadores pré-formados e recém sintetizados de mastócitos e basófilos pode influenciar na maturação e no estado funcional da DC. Estes aspectos da resposta inata, envolvendo a ação do CpG e a capacidade funcional das pDCs, ainda não estudados na UCI, são de grande interesse para a compreensão da imunopatogênese da doença.

\section{JUSTIFICATIVA}

Até o momento não há descrição sobre a resposta imune gerada pelo agonista de TLR-9, o CpG, bem como o efeito modulatório de ODN supressor na UC. A participação das células envolvidas na resposta inata em resposta à ativação via $\mathrm{CpG}$ e dos fatores que influenciam a geração da resposta adaptativa são parâmetros imunológicos importantes para serem elucidados na Urticária Crônica.

Diante dessas evidências, o $\mathrm{CpG}$ pode representar um importante candidato para imunomodulação da resposta imunológica, portanto, é necessário avançar no estudo das células dendríticas plasmocitóides e dos fatores que possam interferir na sua atividade funcional na UCI. 


\section{OBJETIVOS}




\section{OBJETIVOS}

\section{Objetivo Geral}

A proposta do estudo foi avaliar o perfil de resposta imune inata na Urticária Crônica Idiopática (UCI) pela capacidade imunomodulatória in vitro do agonista do receptor Toll-like 9, o oligodeoxinucleotídeo contendo motivos $\mathrm{CpG}$, na produção de citocinas e na ativação das células dendríticas plasmocitóides (pDC).

\section{Objetivos Específicos}

- Avaliar a capacidade de resposta dos leucócitos ao estímulo in vitro com CpGA na produção de citocinas (IFN- $\alpha$, IL-12p40 e IL-10) e do efeito inibitório do ODN-supressor na produção de citocinas induzidas por CpGA (IFN- $\alpha$ e IL-10),

- Avaliar a via de sinalização para a produção de IFN- $\alpha$ pela expressão intracelular de STAT 1 e STAT 4 fosforilada e expressão de mRNA para TLR9 e IRF-7 em células mononucleares após estímulo in vitro com CpGA,

- Quantificar as pDCs (Lin1-, CD304+, CD123+, CD11c-) em células mononucleares do sangue periférico, avaliar a expressão de moléculas coestimuladoras e de ativação (CD80, CD86, CD40) e a expressão intracelular de IFN- $\alpha$, após estímulo in vitro com $\mathrm{CpG}$,

- Caracterizar a presença das pDCs em biópsias de pele de pacientes com UCI. 
III. CASUÍ́STICA

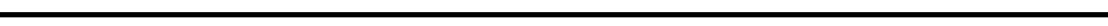




\section{CASUÍSTICA}

Foram selecionados pacientes com quadro de urticária crônica idiopática (UCI), com sintomas recorrentes acima de seis semanas de duração, do Ambulatório de Urticária do Departamento de Dermatologia do Hospital das Clínicas da Faculdade de Medicina da USP. Foram incluídos 26 pacientes com UCI, sendo 24 mulheres e 2 homens, mediana de 52 anos, com variação de 22 a 68 anos. Os pacientes e indivíduos controles foram informados ao termo de consentimento e livre esclarecido para posteriormente serem incluídos no estudo. Os doentes foram submetidos a exames laboratoriais gerais de acordo com a rotina de atendimento do Ambulatório. Este projeto foi aprovado pelo comitê de ética do Hospital das Clínicas da Universidade de São Paulo (CAPPesq nº 0569/07).

O grupo controle foi composto por 50 indivíduos sadios, sendo 44 mulheres e 6 homens, mediana de 43,5 anos, com variação de 21 a 68 anos, sem história de UCI.

\section{Critérios de exclusão}

Pacientes com evidência clínica de urticária-vasculite e urticária física, constituíram critérios de exclusão. O uso de medicação immunosupressora e/ou de anti-histamínicos foi suspenso por pelo menos 48 horas antes da coleta da amostra para a realização do teste de soro autólogo (ASST). 


\section{MATERIAIS E MÉTODOS}




\section{MATERIAIS E MÉTODOS}

\section{Oligodeoxinucleotídeos:}

Oligodeoxinucleotídeos (ODN) CpG com fosforotioato e/ou fosfodiéster, como descrito por Krieg et al. (1995), Shirota et al. (2004) foram sintetizados pela Eurofins MWG Operon (Huntsville, AL, EUA). Os ODNs utilizados estão listados a seguir. As letras maiúsculas e minúsculas indicam ponte fosforotioato e fosfodiéster, respectivamente, na posição $5^{\prime}$.

A) ODN-CpG A 2216: 5' - ggGGGACGATCGTCgggggG - 3'

B) ODN-Controle A 2243 : 5' - ggGGGAGCATGCTCgggggG- 3'

C) ODN-S A151: 5'- TTAGGGTTAGGGTTAGGGTTAGGG -3'

D) ODN-Controle S 1612: 5'- GCTAGAGCTTAGGCT- 3'

\section{Indução de citocinas in vitro por oligonucleotídeos CpG:}

Para verificar o efeito do ODN-CpG A na produção de citocinas (IFN- $\alpha$, IL12p40, IL-10), e a capacidade modulatória do ODN-S (ODN-supressor) na indução de citocinas por ODN-CpGA, leucócitos foram obtidos de sangue periférico e estimulados com variadas concentrações molares de cada ODN ou com a associação dos ODNs.

Para tal, os leucócitos foram obtidos a partir de $10 \mathrm{~mL}$ de sangue periférico em EDTA acrescentado $2 \mathrm{~mL}$ de solução de $\mathrm{NaCl} 0.15 \mathrm{M}$ contendo 5\% de dextran (SigmaAldrich) e 3\% de glicose (Sigma). Após sedimentação por 90 minutos a temperatura ambiente, o sobrenadante foi removido e a suspensão celular lavada por centrifugação em tampão PBS- 0,3\% SAB (soro albumina bovina) e 5mM de glicose (Sigma) pH 7.4 por duas vezes. As células foram ressuspensas em 1,0mL de meio de cultura RPMI- 
1640 suplementado com 5\% de soro fetal bovino inativado (Hyclone III, Lotan CT, EUA), quantificadas e a viabilidade avaliada com corante vital Azul de tripan.

Os leucócitos obtidos foram distribuídos em $100 \mu \mathrm{L} /$ por orifício $\left(5,0 \times 10^{6}\right.$ células/mL) em microplaca de 96 orifícios (Costar, Cambridge, MA, EUA), na presença de $100 \mu \mathrm{L}$ de meio de cultura ou de ODN-CpG A (2216, nas concentrações $0.25,0.50,1$ e $2 \mu \mathrm{M}$ ), ODN-supressor (A151, 0.25, 0.50, 1 e $2 \mu \mathrm{M}$ ) e respectivos ODNs controles, ODNA $(2243,0.25,0.50,1$ e $2 \mu \mathrm{M})$, ODNS $(1612,0.25,0.50,1$ e $2 \mu \mathrm{M})$. Em outros orifícios os leucócitos foram estimulados com ambos os ODNs, CpGA (1 e $2 \mu \mathrm{M})$ e ODN-supressor $(1$ e $2 \mu \mathrm{M})$ por 48 horas a $37^{\circ} \mathrm{C}$. Os sobrenadantes das culturas foram coletados e estocados a $-70^{\circ} \mathrm{C}$ para posterior dosagem de citocinas por ELISA.

\section{Obtenção de células mononucleares (CMN) do sangue periférico:}

Amostras de sangue periférico foram coletadas em tubo heparinizado estéril, diluídas, volume a volume, em solução fisiológica e centrifugadas por 20 minutos a 2200 rpm em solução gradiente de Ficoll-Hypaque (Amersham Pharmacia Biotech, NJ, EUA) para obtenção de CMN. Após duas lavagens em meio de cultura RPMI-1640 (Inlab, Diadema, SP, BR) suplementado com gentamicina $(10 \mu \mathrm{g} / \mathrm{mL}$, Novafarma, SP, BR) a $1100 \mathrm{rpm}$ por 10 minutos, as células obtidas foram quantificadas em contador automático (Cell Dyn 1400, Abbot) e a concentração de células foi ajustada de acordo com o ensaio a ser realizado. A viabilidade celular foi observada com auxílio do corante Azul de tripan.

\section{Avaliação da via de sinalização para a produção de IFN- $\alpha$ :}

A via de sinalização para produção de IFN- $\alpha$ foi avaliada pela fosforilação de STAT1 e STAT4 após estímulo com CpGA e ODN controle. As CMN foram lavadas 
em meio de cultura RPMI-1640 (Inlab, BR) suplementado com gentamicina (10 $\mu \mathrm{g} / \mathrm{mL})$ por centrifugação, quantificadas em contador automático (Cell Dyn 1400, Abbot) e a viabilidade celular foi observada com auxílio do corante Azul de tripan. Posteriormente as CMNs $\left(2 \times 10^{6} / 500 \mu \mathrm{l}\right)$ foram incubadas com $2 \mu \mathrm{M}$ de ODN-CpG A (2216), ou do ODN controle, ODN (2243) em microplacas de 24 orifícios (Costar) por 4 horas a $37^{\circ} \mathrm{C}$. Inicialmente foi realizada uma cinética de fosforilação dos fatores de transcrição nos tempos de 1, 2, 4, 6 e 24 horas após estímulo com CpGA. Após os ensaios de padronização escolheu-se o tempo de 4 horas de cultura.

Permeabilização: As células foram coletadas, lavadas com PBS 1x por 10 minutos a $1100 \mathrm{rpm}$ e fixadas com $300 \mathrm{ul}$ de paraformaldeído $4 \%$ por 10 minutos a $37^{\circ} \mathrm{C}$. Após este período as amostras foram centrifugadas, adicionou-se $1 \mathrm{ml}$ de metanol 90\% gelado e incubou-se no gelo por 30 minutos. Em seguida, os tubos foram preenchidos com PBS e centrifugados por 5 minutos a $1200 \mathrm{rpm}$. Após descarte do sobrenadante, adicionaram-se $100 \mathrm{ul}$ de PBS $2 \%$ de soro fetal bovino e incubou-se a suspensão por 15 minutos à temperatura ambiente para reidratação.

Marcação intracelular: Após reidratação acrescentou-se 200ul de tampão de lavagem (PBS 1x, 2\% de soro fetal bovino) e centrifugou-se a suspensão por 5 minutos a $1200 \mathrm{rpm}$.Ressuspendeu-se o sedimento celular e acrescentou-se 5ul de Alexa-Fluor 488 mouse anti-STAT1 (pY701) (BD, Becton Dickinson, NJ, EUA) ou Alexa-Fluor 488 mouse anti-STAT4 (pY693) (BD, Becton Dickinson, NJ, EUA). Incubou-se a suspensão por 30 minutos em geladeira e no escuro. Após este período as células foram centrifugadas em tampão de lavagem e ressuspendidas em solução isotônica. O número relativo de cada população avaliado pela aquisição de 10.000 eventos em aparelho de citometria de fluxo (Coulter-Epics) utilizando o programa System II Versão 3.0 (Beckman Coulter, Inc- USA). 


\section{Caracterização e quantificação de células dendríticas plasmocitóides (pDC) em} sangue periférico, análise de ativação das pDCs por estímulo com CpG e indução da expressão intracelular de IFN- $\alpha$ :

As pDCs foram analisadas quanto ao número e grau de ativação, pela expressão de moléculas e produção de citocinas em resposta ao estímulo pelo CpGA. Inicialmente as pDCs foram caracterizadas e quantificadas (CD304+, CD11c-, CD123+) em células mononucleares $(\mathrm{CMN})$ do sangue periférico por citometria de fluxo (Coulter- Epics XL, Miami, FL, USA).

Para quantificação das pDCs, células mononucleares (CMN) foram obtidas do sangue periférico heparinizado $(10 \mathrm{~mL})$, diluídas, volume a volume, em solução fisiológica e centrifugada por 20 minutos a $2200 \mathrm{rpm}$ em solução gradiente de FicollHypaque (Amersham Pharmacia Biotech, NJ, EUA). A suspensão de CMN foi lavada por duas vezes em tampão PBS- $0,5 \%$ SAB e marcadas com anticorpos monoclonais, conjugados com isotiocianato de fluoresceína (FITC), ficoeritrina (PE) ou ficoeritrinacianina 5.1 (PC5) com os seus respectivos controles isotípicos. Para a caracterização das pDcs foram utilizados anticorpos para CD304 (BDCA4, Milteyi Biotec, Germany), CD123 (PharMingen, San Diego, CA, USA) e lin 1 (anti-CD3, anti-CD14, anti-CD16, anti-CD19, anti-CD20 e anti-CD56, PharMingen).

Para análise das moléculas co-estimulatórias e de ativação em pDCs após estímulo com CpG, as CMN foram lavadas em meio de cultura RPMI-1640 (Inlab, BR) suplementado com gentamicina $(10 \mu \mathrm{g} / \mathrm{mL})$ por centrifugação, quantificadas em contador automático (Cell Dyn 1400, Abbot) e a viabilidade celular foi observada com auxílio do corante Azul de tripan. Posteriormente as CMNs $\left(2 \times 10^{6} / 500 \mu l\right)$ foram incubadas com $2 \mu \mathrm{M}$ de ODN-CpG A (2216), ou do ODN controle, ODNA (2243) em 
microplacas de 24 orifícios (Costar) por 24 horas a $37^{\circ} \mathrm{C}$. As células foram coletadas para a avaliação das moléculas co-estimulatórias utilizando anticorpos para pDC (lin 1 e 123) e para as moléculas co-estimulatórias CD40, CD80 e CD86 (PharMingen).

Para a marcação intracelular de IFN- $\alpha$ em pDCs, as CMN $\left(2 \times 10^{6} / 500 \mu 1\right) \mathrm{em}$ RPMI-S foram incubadas CpGA ou ODN na presença de inibidor de secreção $(0,5$ $\mu \mathrm{g} / \mathrm{ml}$ de brefeldina A, Sigma) em microplacas de 24 orifícios (Costar) por $24 \mathrm{hrs}$ a $37^{\circ} \mathrm{C}$ e $5 \%$ de $\mathrm{CO}_{2}$. Após a incubação, as $\mathrm{CMN}$ foram lavadas por duas vezes em PBS-SAB $0.1 \%$ de azida sódica e marcadas extracelularmente com acs monoclonais para pDCs como descrito acima. Em seguida, as células foram lavadas com PBS-SAB, fixadas e permeabilizadas em tampão (Fix Perm A e B, Caltag Lab. Inc) e incubadas com anticorpos monoclonais e anti-IFN- $\alpha$ marcados com PE ou anticorpos isotípicos (BD Biosciences).

As células foram ressuspendidas em solução isotônica e o número relativo de cada população avaliado pela aquisição de 10.000 eventos em aparelho de citometria de fluxo (Coulter-Epics) utilizando o programa System II Versão 3.0 (Beckman Coulter, Inc- USA).

\section{Ensaio imunoenzimático (ELISA) para dosagem de citocinas:}

A determinação das citocinas IFN- $\alpha$, IL-10 e IL-12p40 nos sobrenadantes de cultura foi realizada por ELISA, seguindo as especificações do fabricante (R\&D System).

Microplacas com 96 poços (A-2, Costar) foram sensibilizadas com anticorpos monoclonais anti-citocinas diluídos em PBS e incubadas por 18 horas a temperatura ambiente. As placas foram bloqueadas com PBS/SAB 4\% (Sigma) e incubadas por uma hora a temperatura ambiente. Em seguida, após um ciclo de três lavagens com tampão PBS/0,05\% Tween-20, foram adicionadas as amostras e as diluições seriadas da curva 
padrão. As placas foram incubadas por uma hora a temperatura ambiente e, após o término deste período, os respectivos anticorpos anti-citocinas biotinilados foram adicionados às placas e incubados por 1 hora a temperatura ambiente. A seguir, após um ciclo de três lavagens, foi adicionada estreptoavidina peroxidase (Sigma) seguida de uma incubação de 45 minutos a temperatura ambiente. Após novas lavagens, foi adicionado o substrato 3, 3', 5, 5' tetrametilbenzidina (TMB, Calbiochem, EUA). A reação foi interrompida pela adição de ácido sulfúrico $1 \mathrm{M}$ e a leitura foi realizada em leitor de microplacas de Elisa (Molecular Devices, CA, EUA) a $450 \mathrm{~nm}$.

\section{Reação em cadeia da polimerase em tempo real:}

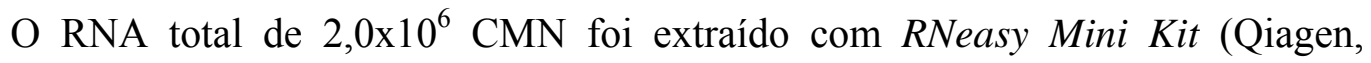
Valencia, CA,USA) seguindo as orientações fornecidas pelo fabricante. Para obtenção de cDNA a partir do RNA total purificado foi utilizada a metodologia do kit Sensiscript Reverse Transcriptase (Qiagen). O procedimento da PCR em tempo real foi realizada como descrito previamente (Dos Santos et al., 2008).

Para a realização da reação de amplificação em tempo real, foram utilizados para cada amostra de cDNA $(1 \mu \mathrm{g}) 10 \mu \mathrm{L}$ da solução Platinum SYBR Green qPCR SuperMixUDG (Invitrogen, Carlsbad, CA, EUA), $0,4 \mu \mathrm{L}$ de $R O X$ Reference Dye, $7,3 \mu \mathrm{L}$ de água destilada estéril e 200nM do primer (Invitrogen). A síntese dos primers foram sintetizados pela Invitrogen (São Paulo, SP, BR). Sequência dos primers: albumina

(sense 5'-GCTGTCATCTCTTGTGGGCTGT-3', antisense 5'-AAACTCATGGGAGCTGCTGGTT-3'); TLR-9 (sense 5'- ACAACAACATCCACAGCCAAGT GTC-3', antisense 5'-AAGGCCAGGTAATTGTCACGGAG-3'), IRF7: (sense 5'TGGTCCTGGTGAAGCTGGAA-3' antisense 5'-GATGTCGTCATAGAGGCTGTTG 
G-3'). A amplificação foi realizada a 45 ciclos de 15 segundos a $95^{\circ} \mathrm{C}, 30$ segundos a $60^{\circ} \mathrm{C}$ e 30 segundos a $72^{\circ} \mathrm{C}$, em termociclador iCycler (BioRad, EUA). Os dados obtidos foram interpretados com o programa iCycler iQ Program (BioRad).Os resultados foram avaliados pelo threshold cycle (ct) do gene de interesse nomalizado com o ct do controle interno (albumina). A expressão quantitativa relativa dos genes foram calculadas como $2^{-\Delta \Delta \mathrm{CT}}$ de acordo com Livak et al. (2001).

\section{Imunoistoquímica para a demonstração de células dendríticas plasmocitóides CD123 positiva em biópsias de pele:}

Cortes histológicos de quatro $\mu \mathrm{m}$ de espessura foram obtidos a partir de material embebido em parafina e colhidos em lâminas previamente preparadas com solução adesiva de 3 amino-propyltriethoxy-silane (Sigma Chemical Co., St. Louis, MO/USA, cód. A3648) a 2\%. A seguir, os cortes histológicos foram desparafinizados em três banhos de xilol à temperatura ambiente durante 20 minutos cada. Posteriormente, foram hidratados em seqüência decrescente de etanol (absoluto, 95\% e 70\%) e água corrente durante cinco minutos cada.

O bloqueio de peroxidase endógena foi feito em câmara escura com seis incubações em água oxigenada 3\% por 10 minutos cada. Em seguida as lâminas foram lavadas em água corrente e água destilada por cinco minutos cada e submersas em solução salina tamponada (PBS) pH 7.4.

Para pesquisa de células dendríticas plasmocitóides CD123+ fez-se a exposição antigênica em calor úmido (panela a vapor) no tampão Retrieval $\mathrm{pH} \quad 6.0$ (DakoCytomation, Carpinteria, CA, USA código S1699). A seguir as lâminas foram lavadas em água corrente e água destilada por cinco minutos cada. 
Previamente à incubação com os anticorpos primários, foi feito o bloqueio de proteínas inespecíficas do tecido com incubação em solução de leite desnatado (Molico, Nestlé $^{\circledR}$ ) a $10 \%$ durante 40 minutos à temperatura ambiente.

As lâminas foram incubadas com o anticorpo primário monoclonal anti-CD123 (eBioscience), diluído a 1:25 e1:50 em solução de albumina bovina (BSA) fração $\mathrm{V}$ (SERVA. 1930) 1\% acrescida de azida sódica 0,1\% em PBS pH 7.4, por $18 \mathrm{hrs} \mathrm{a} 4^{\circ} \mathrm{C}$.

As lâminas foram incubadas com "Post primary block" (NovoLink ${ }^{\mathrm{TM}}$ Max Polymer Detection System, Novocastra ${ }^{\mathrm{TM}}$, código RE7280-K) por 30 minutos a $37^{\circ} \mathrm{C}$. As lâminas foram novamente lavadas por duas vezes durante cinco minutos cada em PBS pH 7.4. Posteriormente, os cortes histológicos foram incubados com antiimunoglobulina de camundongo/coelho -"NovoLink ${ }^{\mathrm{TM}}$ Polymer" (NovoLink ${ }^{\mathrm{TM}}$ Max Polymer Detection System, Novocastra ${ }^{\mathrm{TM}}$, código RE7280-K) por 30 minutos a $37^{\circ} \mathrm{C}$.

A seguir, os sítios de ligações foram revelados com solução cromógena de diaminobenzidina (3,3'-diaminobenzidine, SIGMA Chemical Co., St. Louis, MO/USA) 0,03\% acrescida de 1,2 $\mathrm{ml}$ de água oxigenada 3\%. A intensidade da cor foi controlada ao microscópio óptico através do controle positivo que acompanhou a reação. Biopsias de lupus eritematoso ou de líquen plano para as células foram utilizadas como controles positivos da reação.

Os cortes, após os procedimentos de revelação das reações foram lavados em água corrente por cinco minutos, contracorados com Hematoxilina de Carazzi por 28 segundos, lavados em água corrente, desidratados em etanol e diafanizados em xilol. A montagem das lâminas foi feita com resina Permount (FISHER Scientific, Fair Lawn, NJ/USA, cód. SP15-100). 


\section{Análise estatística:}

O Mann-Whitney $U$ test foi utilizado para comparar variáveis entre pacientes com UCI e indivíduos controles. Para analisar a diferença de expressão de cultura de células estimulada das não estimulada (basal) foi utilizado o método não paramétrico pareado de Wilcoxon. $\mathrm{O}$ valor de $P$ menor que 0,05 foi considerado significante. 


\section{V.RESULTADOS}




\section{RESULTADOS}

1. Características demográficas dos pacientes com Urticária Crônica Idiopática.

Para o estudo foram selecionados 26 pacientes com Urticária Crônica Idiopática (UCI) do Ambulatório de Dermatologia HC-FMUSP (Tabela I). A distribuição dos pacientes por sexo foi predominante de mulheres (24) em relação aos homens (2), com idade mediana de 52 anos. A média de duração da doença foi de 12,63 anos $\pm 14,49$. As características individuais dos pacientes com UCI encontram-se na Tabela III (Anexo I).

TABELA I. Característica demográfica dos pacientes com Urticária Crônica Idiopática

\begin{tabular}{c|c}
\hline $\mathbf{N}^{\mathbf{0}}$ Pacientes & 26 \\
Mulheres/Homens & $24 / 2$ \\
Idade & 52 anos * \\
(variação) & $(22-68$ anos) \\
& \\
Duração da doença & $12,63 \pm 14,49$ anos \\
\hline mediana
\end{tabular}




\section{Característica dos pacientes com Urticária Crônica Idiopática submetidos ao} teste de soro autólogo.

Os pacientes com UCI foram submetidos ao teste cutâneo para detecção de autoanticorpos anti-FceRI, como descrito por Sabroe et al., 1999.

A Tabela II mostra que o teste de soro autólogo (ASST) apresentou resultado positivo em $9(40,9 \%)$ pacientes (ASST+) sendo que 13 pacientes $(59,0 \%)$ foram negativos para o teste (ASST-). Em relação ao ASST a distribuição de sexo foi semelhante. A média de duração da doença dos pacientes ASST+ foi de 7,93 $\pm 9,57$ anos e de 16,40 $\pm 17,03$ anos, nos indivíduos ASST-.

A ocorrência de angioedema foi detectável em 87,5\% dos pacientes ASST+ e $60,0 \%$ dos ASST-. A presença de autoanticorpos anti-fator nuclear (FAN), antitireoglobulina (TG) e anti-tiroperoxidase (TPO) foi avaliada na coorte de pacientes com UCI (Tabela II). Foi evidenciada uma freqüência de 4,0\% de autoanticorpos anti-TG, $8,0 \%$ de FAN e $8,0 \%$ de anti-TPO nos subgrupos de pacientes avaliados. O padrão predominante de autoanticorpos anti-fator nuclear foi pontilhado fino. Apesar da elevada frequência de autoanticorpos na coorte de pacientes com UCI, uma similaridade de freqüência de autoanticorpos independente da reatividade do teste de soro autólogo. 
TABELA II. Característica dos pacientes com Urticária Crônica Idiopática submetidos ao teste de soro autólogo.

\begin{tabular}{c|c|c}
\hline & ASST+ & ASST- \\
\hline $\mathbf{N}^{\mathbf{0}}$ pacientes (\%) & $9(40,9)$ & $13(59,0)$ \\
\hline Mulheres / Homens & $8 / 01$ & $12 / 01$ \\
\hline Duração da doença & & \\
em anos & $7,93( \pm 9,57)$ & $16,40( \pm 17,03)$ \\
média (D.P.) & & $1 / 12(8,33)$ \\
\hline Angioedema (\%) & $7 / 8(87,5)$ & $6 / 10(60,0)$ \\
\hline anti-TPO & $1 / 9(11,11)$ & $1 / 13(7,69)$ \\
\hline anti-TG & & $11,11)$ \\
\hline
\end{tabular}

Autoanticorpos: fator anti-fator nuclear (FAN), anti-tireoglobulina (TG) e antitireoperoxidase (TPO) 


\section{Dosagem de citocinas em sobrenadantes de culturas de pacientes com UCI e controles estimuladas por oligonucleotídeos CpG.}

Para avaliar o efeito de agonistas de TLR-9 ou imunomodulatório do oligonucleotídeo (ODN)-supressor $(\mathrm{S})$, na produção de citocinas por células que participam da resposta inata na UCI, os leucócitos de pacientes ou de controles foram isolados por dextran 5\% e cultivados por 48 horas na presença de ODN-CpGA (2216, $0.25,0.50,1$ e $2 \mu \mathrm{M})$, ODN-S (A151, 0.25, 0.50, 1 e $2 \mu \mathrm{M}$ ) e seus respectivos ODNs controles nas mesmas concentrações. Considerando que os ODNs CpG são capazes de estimular as células dendríticas plasmocitóides, macrófagos, linfócitos B e capazes de induzir a secreção de citocinas como a IL-10, IL-12p40 e IFN- $\alpha$ (KLINMAN et al., 1996; SPARWASSER et al., 1998), estas citocinas foram avaliadas nos sobrenadantes das culturas.

A Figura 3a mostra que o estímulo com CpGA é capaz de induzir a secreção de IL10 de células dos pacientes e de indivíduos normais. Entretanto, esta produção foi significativamente aumentada à partir de $0,5 \mu \mathrm{M}$ em relação ao respectivo ODN controle somente no grupo controle. O CpGA também foi capaz de estimular a produção de IFN- $\alpha$ em níveis superiores aos detectados com o ODN controle, independente da concentração molar (Fig 3b). Os níveis de IFN- $\alpha$ secretados foram quase indetectáveis nos pacientes $(<25 \mathrm{pg} / \mathrm{ml})$, sendo que as concentrações de 1 e $2 \mu \mathrm{M}$ foram significativamente diminuídos quando comparados com os indivíduos normais (Fig 4). Já os níveis de IL-10 induzidos por CpGA foram diminuídos nos pacientes somente na concentração de $2 \mu \mathrm{M}$ (Fig 4).

Nos sobrenadantes de culturas estimuladas pelo ODN-S observou-se indução de IL-12p40 tanto pelas células de pacientes como de controles (Fig. 5). Na concentração 
de $0.25 \mu \mathrm{M}$ de ODN supressor, a secreção de IL-12p40 foi significativamente aumentada quando comparada ao ODN controle. Ao compararmos pacientes e controles observamos que com $0.25 \mu \mathrm{M}$ a produção de IL-12p40 nos pacientes foi significativamente diminuída (Fig. 6). Na concentração de 2,0 $\mu \mathrm{M}$ de ODN-S, 40\% dos controles secretaram IL-12p40 enquanto que, na mesma concentração, esta citocina foi detectada em apenas $6,25 \%$ dos pacientes. 
Controle

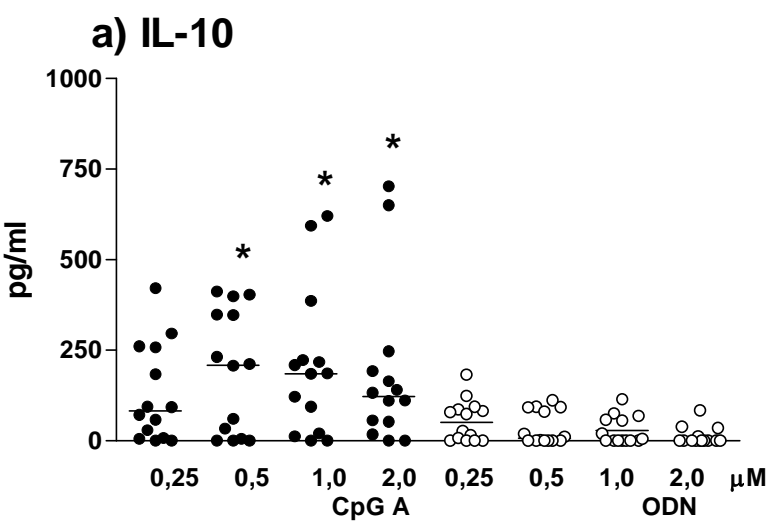

b) IFN- $\alpha$

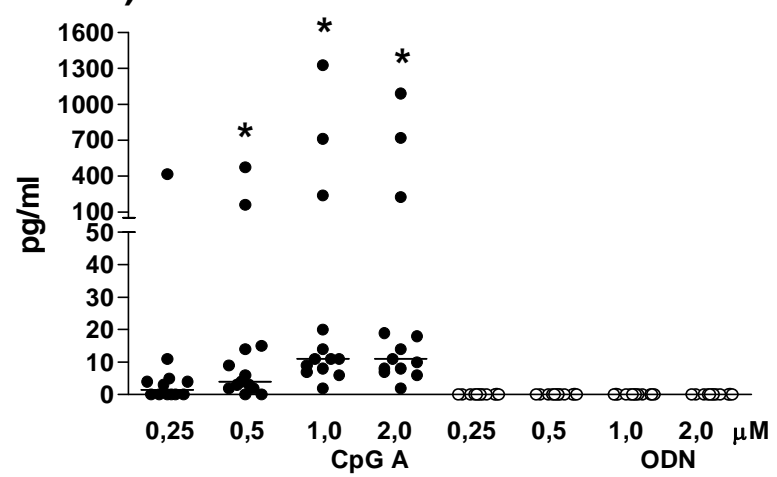

$\mathrm{UCl}$
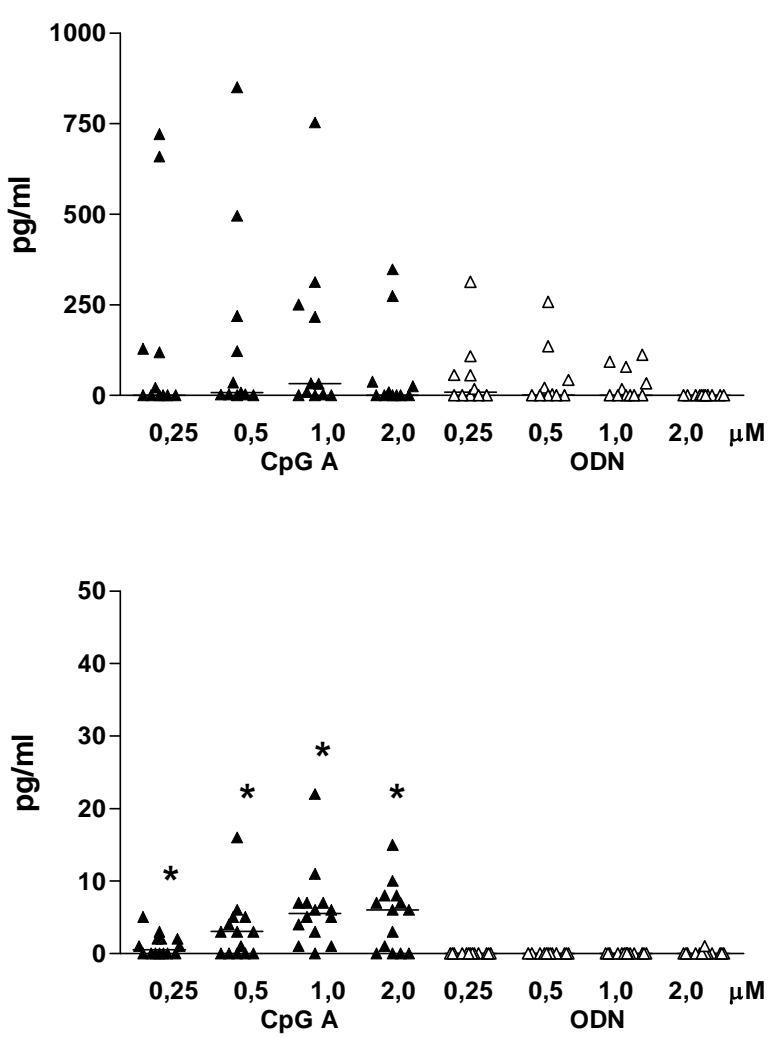

Figura 3. Dosagem de IL-10 e IFN- $\alpha$ em sobrenadantes de culturas de leucócitos de pacientes com UCI estimulados por CpGA. Leucócitos de pacientes e controles foram estimulados com CpGA e ODN controle $(0,25 ; 0,5 ; 1,0 ; 2,0 \mu \mathrm{M})$ e incubados por 48h. Os sobrenadantes foram coletados e as concentrações de IL-10 e IFN- $\alpha$ foram determinadas por ELISA. Os resultados são expressos individualmente e a linha horizontal representa a mediana do grupo. * $P \leq 0,05$ quando comparado ao ODN controle na mesma concentração. 
IL-10

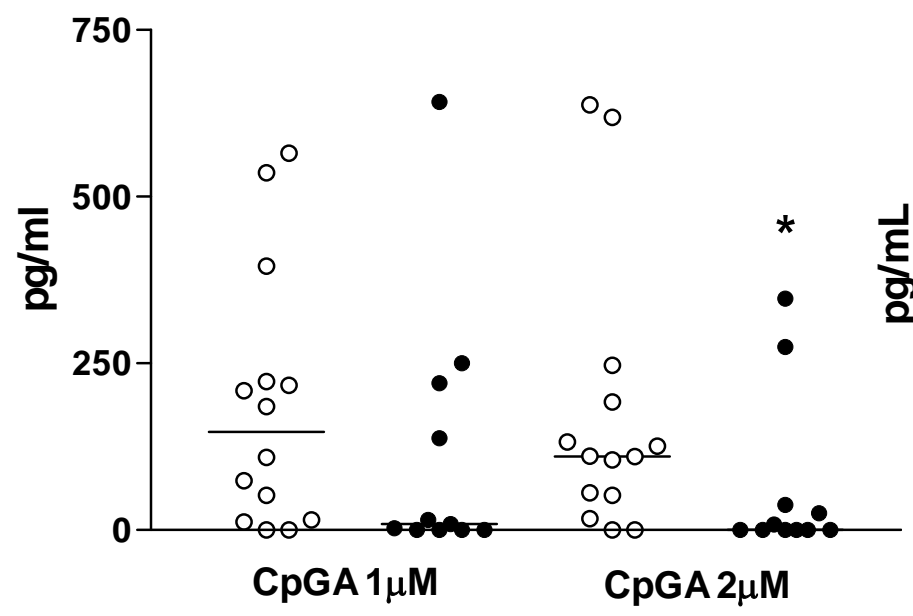

IFN- $\alpha$

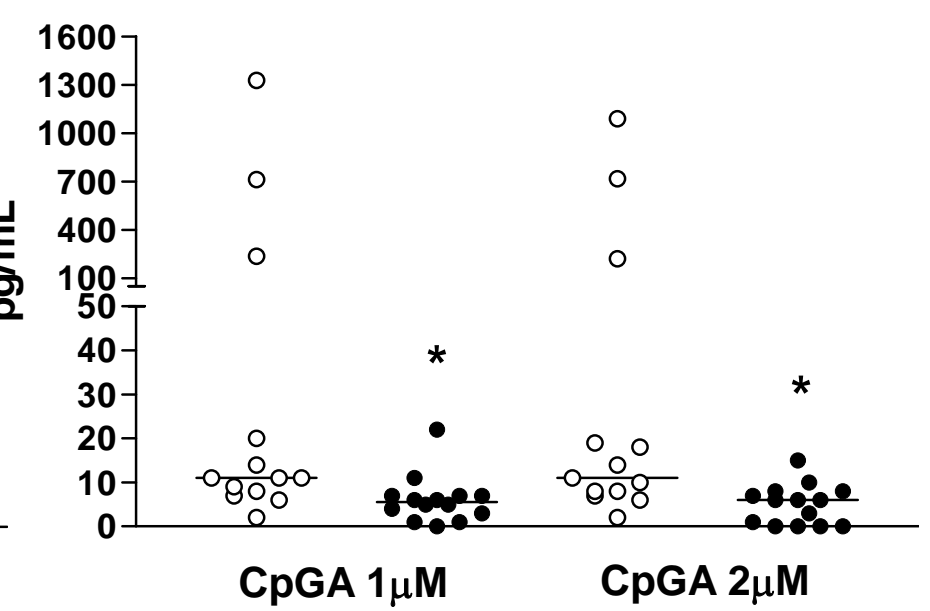

Figura 4. Dosagem de IL-10 e IFN- $\alpha$ em sobrenadantes de culturas de leucócitos de pacientes com UCI estimulados por CpGA. Leucócitos de pacientes e controles foram estimulados com CpGA $(1,0 ; 2,0 \mu \mathrm{M})$ e incubados por $48 \mathrm{~h}$. Os sobrenadantes foram coletados e as concentrações das citocinas foram determinadas por ELISA. Os resultados são expressos como o valor obtido da subtração do CpGA com o ODN controle e a linha horizontal representa a mediana do grupo. * $P \leq 0,05$ quando comparado com indivíduo saudável (controle). 

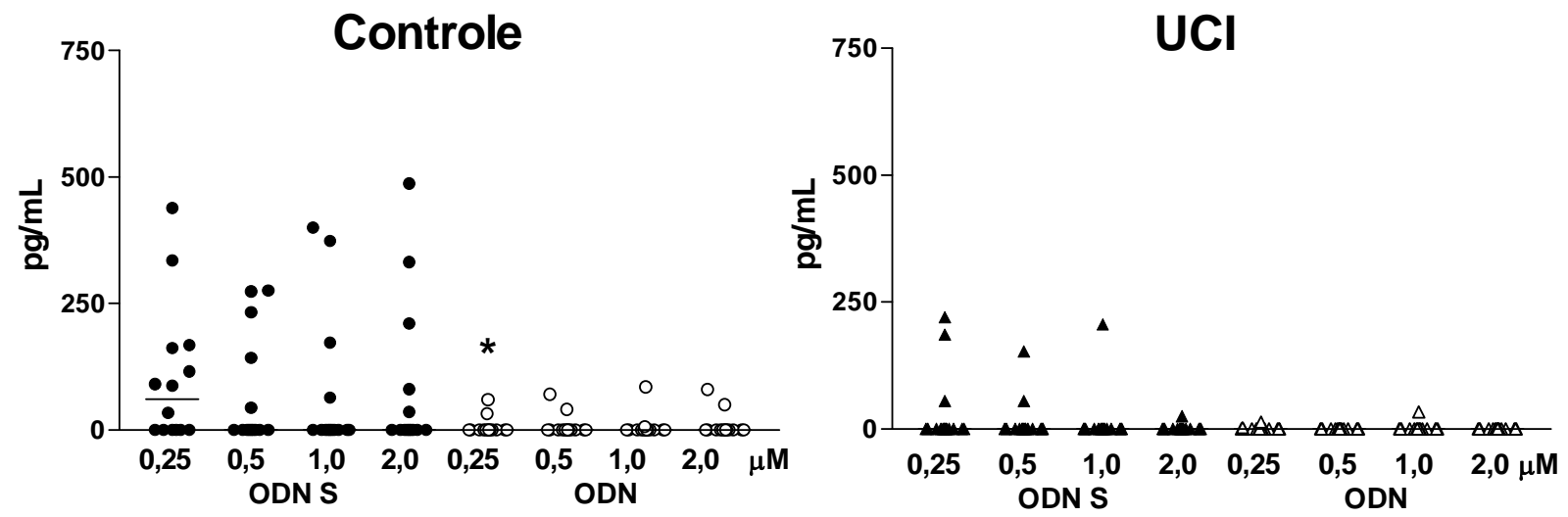

Figura 5. Dosagem de IL-12p40 em sobrenadantes de culturas de leucócitos de pacientes com UCI estimulados por ODN-S. Leucócitos de pacientes e controles foram estimulados com ODN-S e ODN controle $(0,25 ; 0,5 ; 1,0 ; 2,0 \mu \mathrm{M})$ e incubados por 48h. Os sobrenadantes foram coletados e as concentrações de IL-12p40 foram determinadas por ELISA. Os resultados são expressos individualmente e a linha horizontal representa a mediana do grupo. * $P \leq 0,05$ quando comparado ao ODN controle na mesma concentração. 


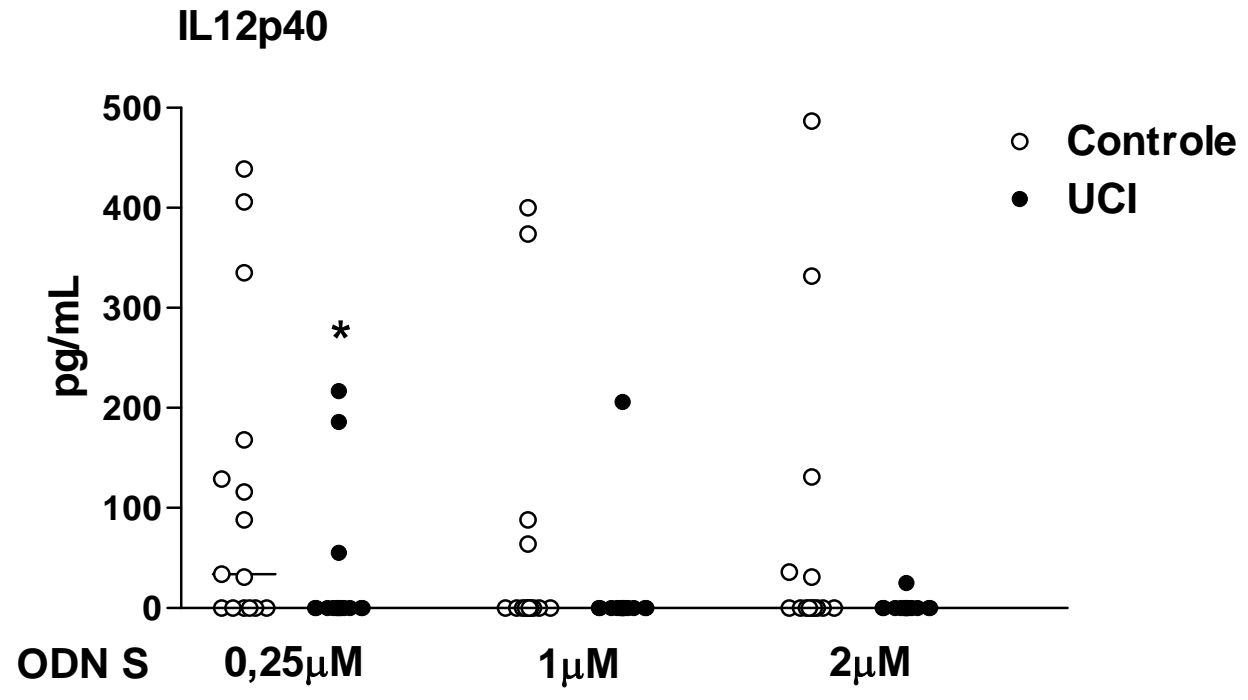

Figura 6. Dosagem de IL-12p40 em sobrenadantes de culturas de leucócitos de pacientes com UCI estimulados por ODN-S. Leucócitos de pacientes e controles foram estimulados com ODN-S $(0,25,1,0,2,0 \mu \mathrm{M})$ e incubados por $48 \mathrm{~h}$. Os sobrenadantes foram coletados e as concentrações das citocinas foram determinadas por ELISA. Os resultados são expressos como o valor obtido da subtração do ODN-S com o ODN controle e a linha horizontal representa a mediana do grupo. ${ }^{*} P \leq 0,05$ quando comparado com indivíduo saudável (controle). 


\section{Efeito modulatório do ODN-S na produção de citocinas induzidas por oligonucleotídeos CpGA.}

Para avaliar se o efeito imunomodulatório do ODN supressor na produção de IFN- $\alpha$ induzida pelo CpGA, foram realizadas culturas de leucócitos de pacientes com UCI e controles na presença de ambos, CpGA e ODN-S nas concentrações de 1 e $2 \mu \mathrm{M}$ de cada ODN por 48 horas de incubação. A adição do ODN-S nas culturas estimuladas por CpGA foi capaz de suprimir significativamente a secreção de IL-10 e IFN- $\alpha$ nos controles em ambas as concentrações e nos pacientes na concentração de $1 \mu \mathrm{M}$ (Fig. 7 e Fig. 8, respectivamente).

Os achados mostram que a estimulação induzida por $\mathrm{CpG}$, seja do tipo A ou supressor nos pacientes com UCI é diminuída, sugerindo uma deficiência na ativação da resposta imune inata na UCI. 

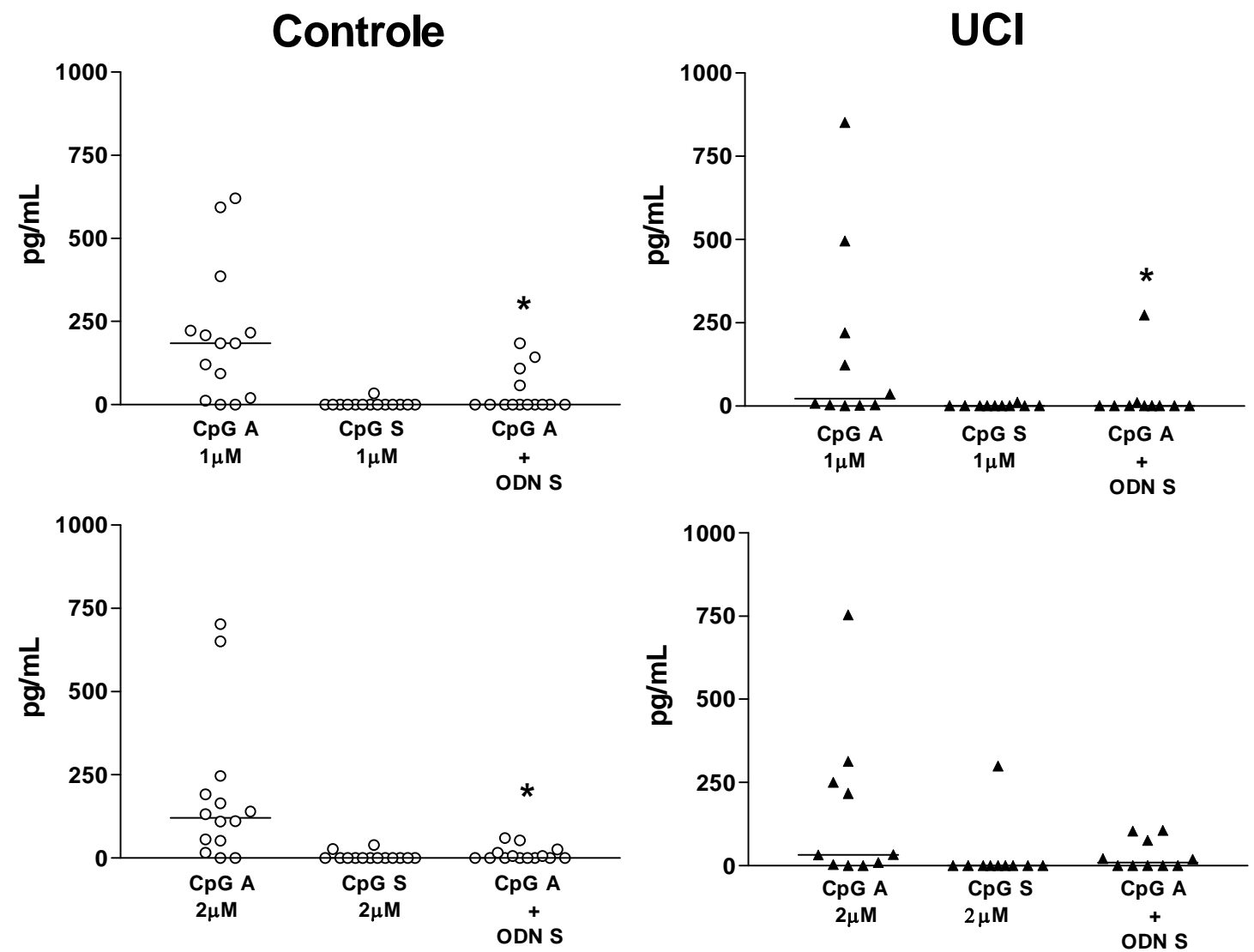

Figura 7. Efeito modulatório do ODN-S na produção de IL-10 em sobrenadantes de culturas de leucócitos estimulados por CpGA. Leucócitos de pacientes e controles foram estimulados com 1,0 e 2,0 $\mathrm{MM}$ de CpGA ou ODN-S ou ambos (CpGA+ODN-S) e incubados por $48 \mathrm{~h}$. Os sobrenadantes foram coletados e as concentrações de IL-10 determinadas por ELISA. Os resultados são expressos individualmente e a linha horizontal representa a mediana do grupo. $* P \leq 0,05$ quando comparado ao CpGA. 
Controle
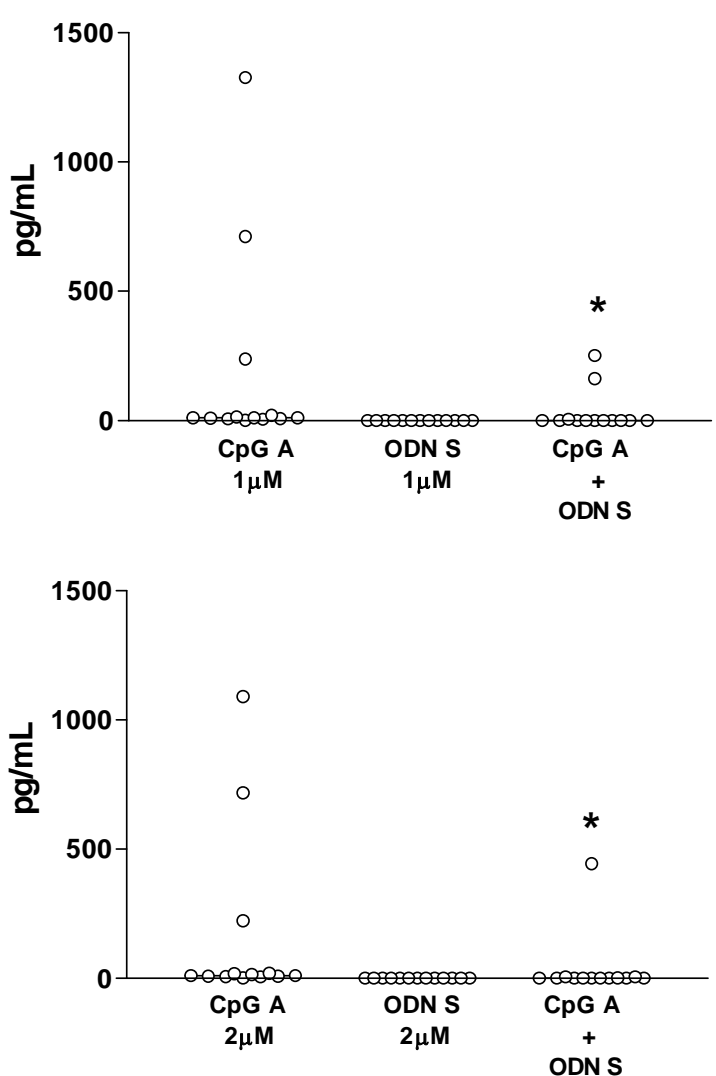

UCI
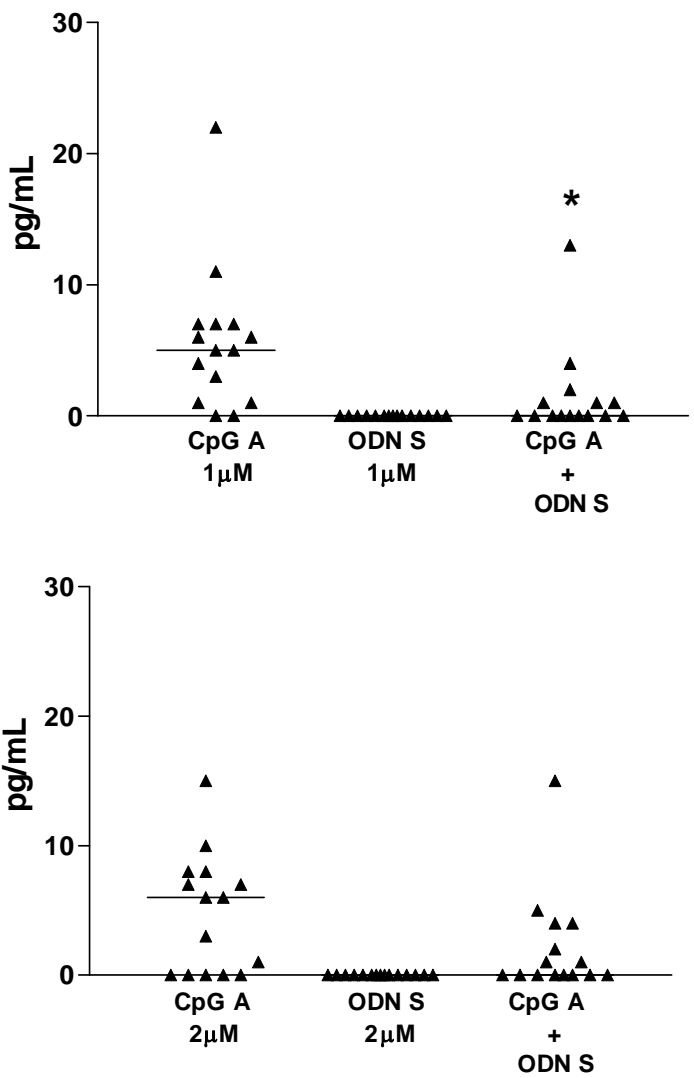

Figura 8. Efeito modulatório do ODN-S na produção de IFN- $\alpha$ de leucócitos de pacientes com UCI estimulados por CpGA. Leucócitos de pacientes e controles foram estimulados com 1,0 e 2,0 $\mathrm{MM}$ de CpGA ou ODN-S ou ambos (CpGA+ODN-S) e incubados por $48 \mathrm{~h}$. Os sobrenadantes foram coletados e as concentrações de IFN- $\alpha$ determinadas por ELISA. Os resultados são expressos individualmente e a linha horizontal representa a mediana do grupo. $* P \leq 0,05$ quando comparado ao CpGA. 


\section{Análise da via de sinalização IFN- $\alpha$ em CMN após estímulo in vitro com CpGA.}

Com o objetivo de verificar se a baixa produção de IFN- $\alpha$ no sobrenadante de pacientes UCI após estímulo com CpGA observada em pacientes UCI estaria relacionada a um defeito na via de sinalização para a produção de IFN- $\alpha$ analisamos a fosforilação de STAT1 e STAT4 por citometria de fluxo. STAT1 e STAT4 são fatores de transcrição envolvidos na sinalização para a produção de IFN- $\alpha$ via IFNR que atuam na retroalimentação para a produção da citocina.

A Figura 9 mostra os histogramas obtidos com a fosforilação de STAT1 e STAT4 em CMN de um individuo saudável, na condição basal e após estímulo com CpGA. A expressão intracelular de STAT1 e STAT4 fosforilada foi avaliada quando ao percentual de células, média de intensidade de fluorescência (MFI) da população de mononucleares e MFI da população positiva.

Observamos que após estímulo com CpGA houve um aumento significativo do percentual de fosforilação de STAT1 (Figura 10a), MFI da população total (Figura 10b) e da população positiva de STAT1 (Figura 11) em indivíduos controle e pacientes UCI comparado a condição basal. É importante salientar que não houve fosforilação de STAT1 após estímulo com ODN controle, ou seja, a expressão de STAT1 foi semelhante aos níveis basais. Ao compararmos o grupo controle com os pacientes UCI observamos um aumento significativo no percentual de fosforilação e MFI da população total de CMN de STAT1 de pacientes UCI em relação ao grupo controle na condição basal (Figura 14).

Em contraste, a fosforilação de STAT4 aumentou quanto ao percentual (Figura 12a) e ao MFI da população total de CMN (Figura 12b) no grupo controle após estímulo com CpGA, mas não na população positiva (Figura 13). Não houve fosforilação após estímulo com ODN controle. Apesar de nenhuma diferença ter sido observada quando 
comparamos indivíduos saudáveis com pacientes UCI (Figura 14), é interessante que o estímulo com CpGA é capaz de induzir fosforilação de STAT4 somente no grupo controle, podendo indicar uma alteração na sinalização para a produção de IFN- $\alpha$ nos pacientes UCI.
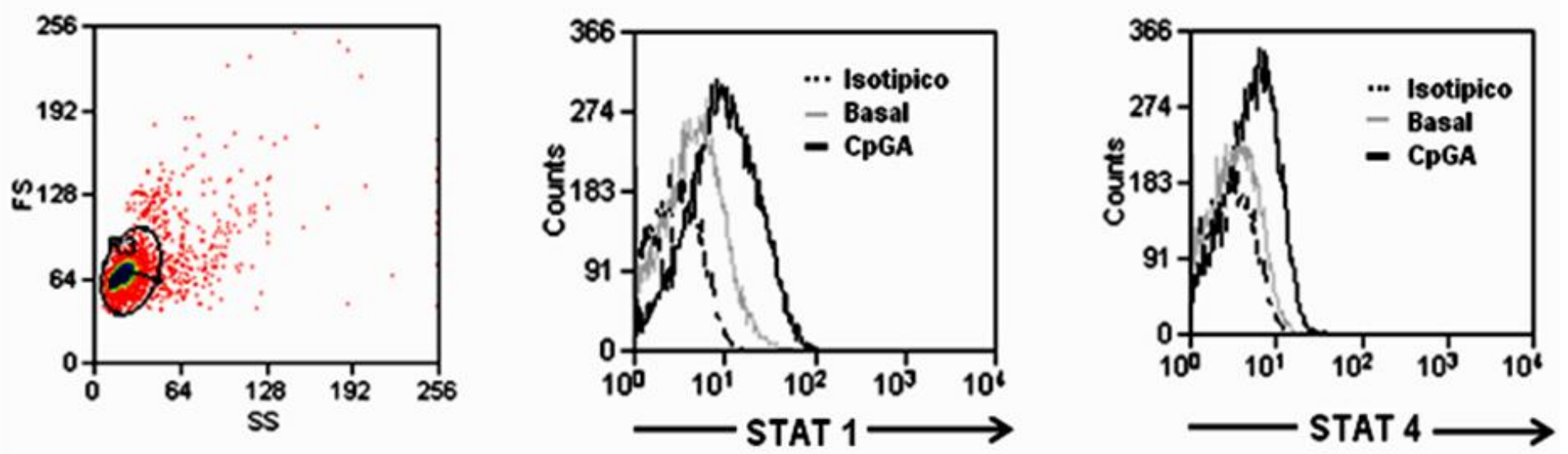

Figura 9. Histograma ilustrativo da expressão intracelular de STAT1 e STAT4 em células mononucleares após estímulo in vitro com CpGA. Células mononucleares de um indivíduo saudável foram cultivadas na presença ou não de CpGA $(2,0 \mu \mathrm{M})$ por $4 \mathrm{~h}$ e analisadas por citometria de fluxo, quanto a fosforilação de STAT1 e STAT4. A figura mostra os histogramas representativos de um experimento. 
a)

Controle
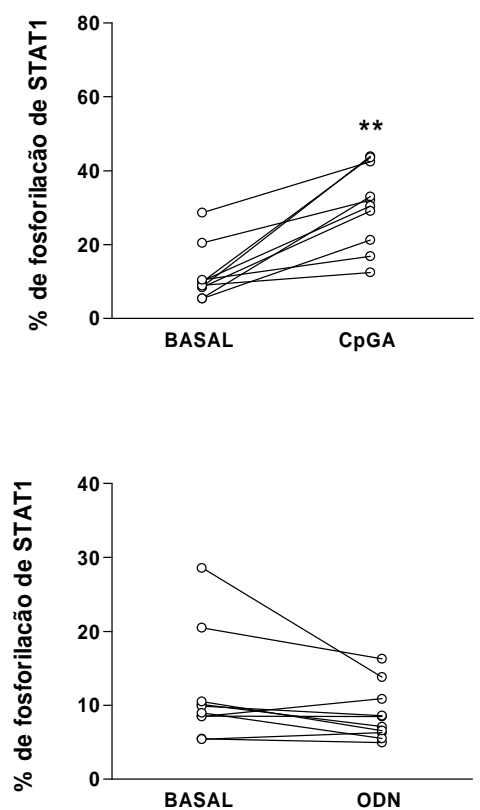

b)
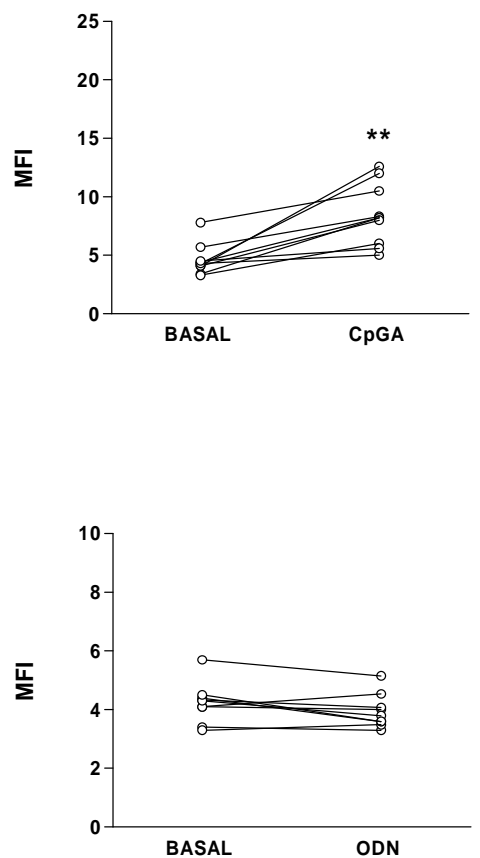

$\mathrm{UCl}$
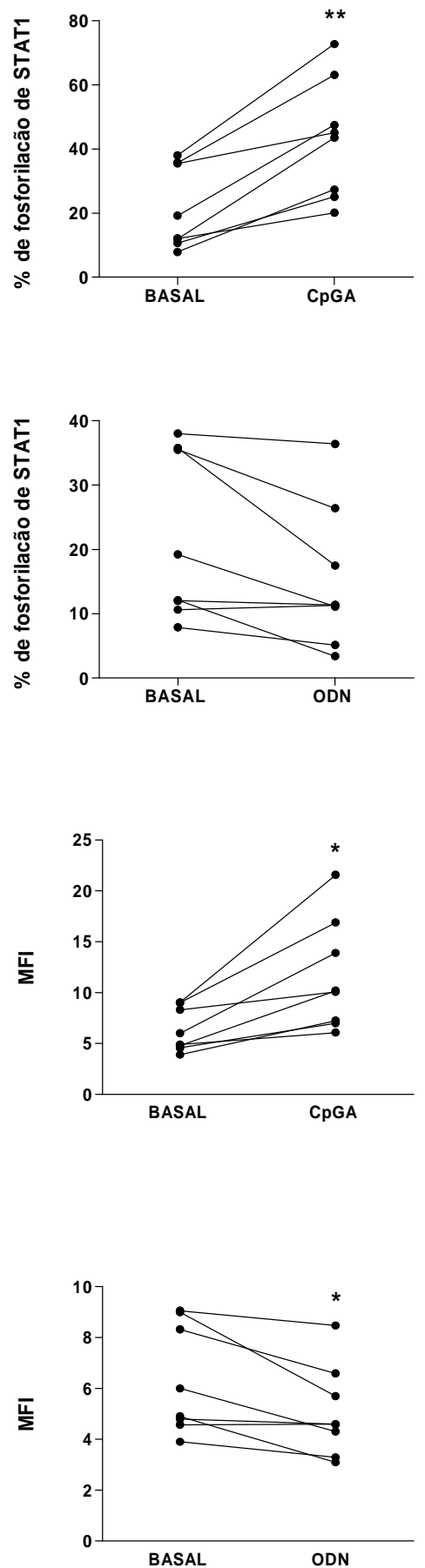

Figura 10. Expressão intracelular de STAT1 em CMN após estímulo in vitro com CpGA. Células mononucleares de indivíduos sadios $(n=10)$ e pacientes UCI $(\mathrm{N}=8)$ foram cultivadas na presença ou não de CpGA ou ODN $(2,0 \mu \mathrm{M})$ por $4 \mathrm{~h}$ e analisadas por citometria de fluxo, quanto a fosforilação de STAT1. a) \% de fosforilação de STAT1, b) MFI da população total de células mononucleares. $* \mathrm{P} \leq 0.05,{ }^{*} \mathrm{P} \leq 0.01$ quando comparado ao basal. 

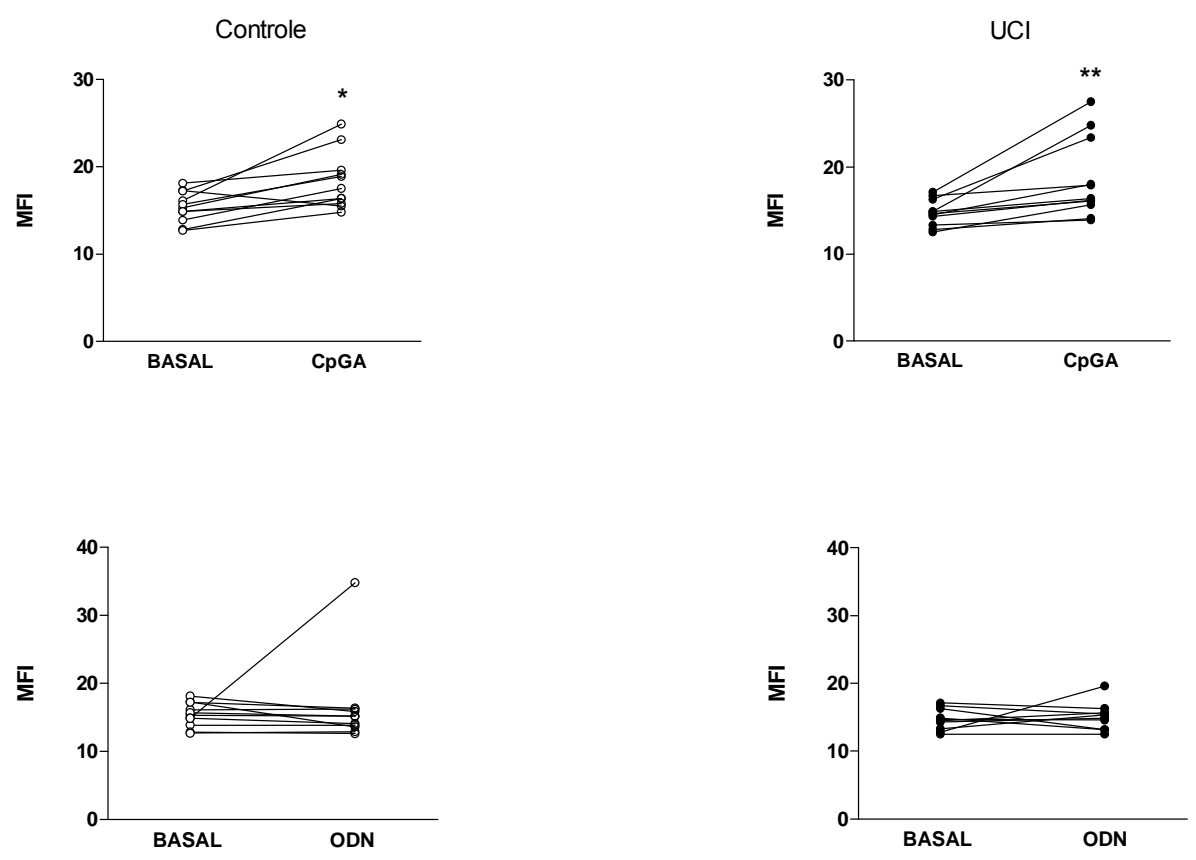

Figura 11. Expressão intracelular de STAT1 em CMN após estímulo in vitro com CpGA. Células mononucleares de indivíduos sadios $(\mathrm{n}=10)$ e pacientes UCI $(\mathrm{N}=8)$ foram cultivadas na presença ou não de CpGA ou ODN $(2,0 \mu \mathrm{M})$ por $4 \mathrm{~h}$ e analisadas por citometria de fluxo, quanto a fosforilação de STAT1. Os resultados representam a intensidade média de fluorescência (MFI) da população positiva. $* \mathrm{P} \leq 0.05, * * \mathrm{P} \leq 0.01$ quando comparado ao basal. 
a)
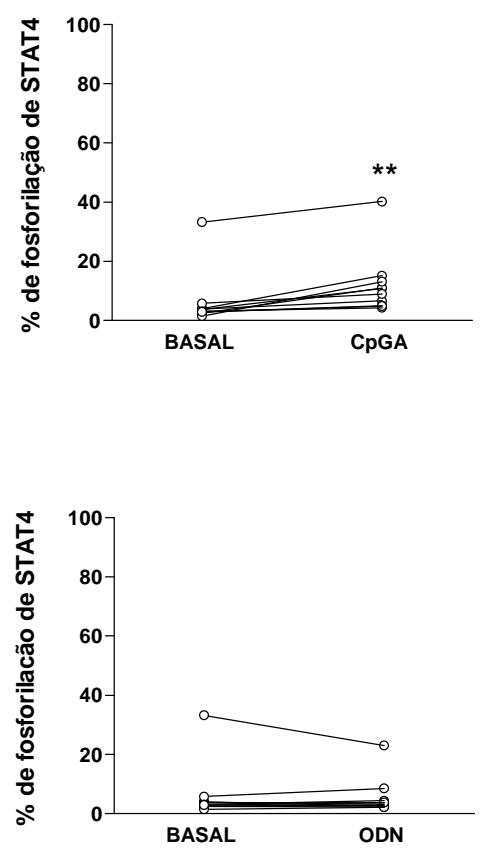

b)
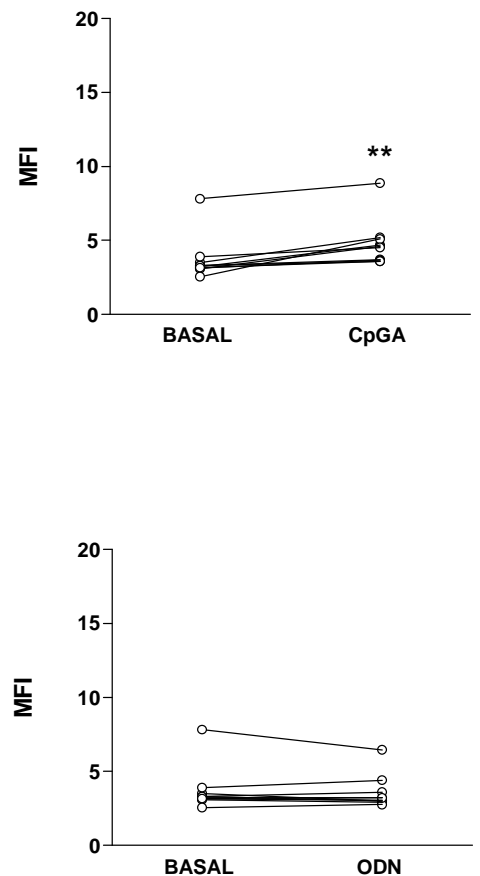

$\mathrm{UCl}$
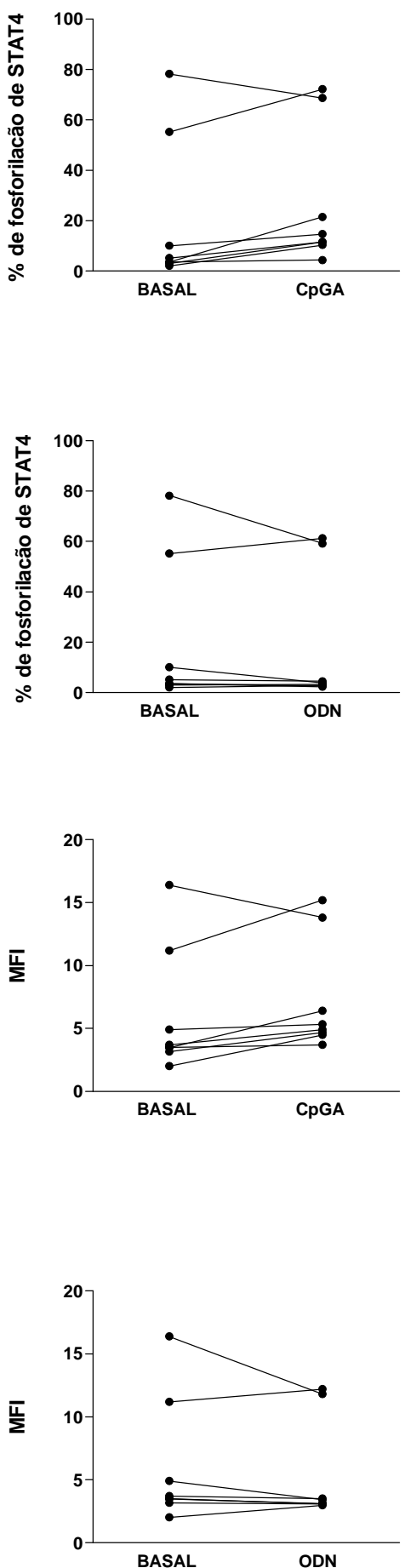

Figura 12. Expressão intracelular de STAT4 em CMN após estímulo in vitro com CpGA.

Células mononucleares de indivíduos sadios $(\mathrm{n}=10)$ e pacientes UCI $(\mathrm{N}=8)$ foram cultivadas na presença ou não de CpGA ou ODN $(2,0 \mu \mathrm{M})$ por $4 \mathrm{~h}$ e analisadas por citometria de fluxo, quanto a fosforilação de STAT4. a) \% de fosforilação de STAT4, b) MFI da população total de células mononucleares. ${ }^{* *} \mathrm{P} \leq 0.01$ quando comparado ao basal. 
Controle
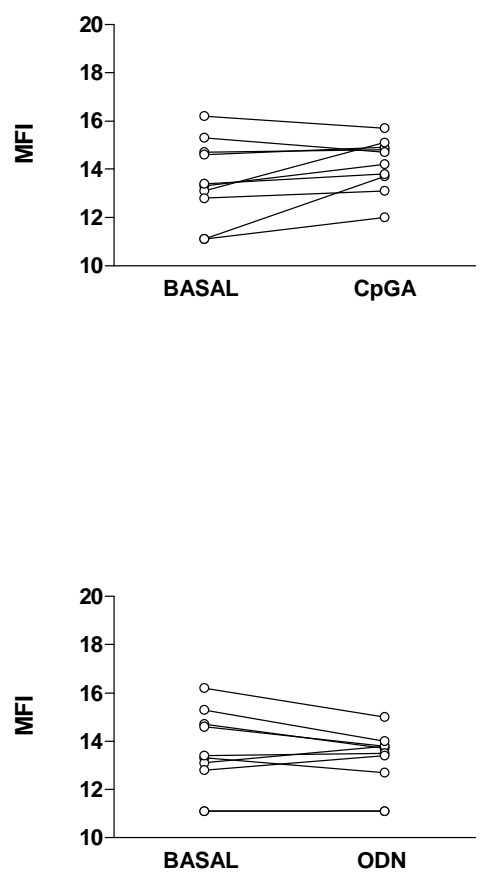

$\mathrm{UCl}$
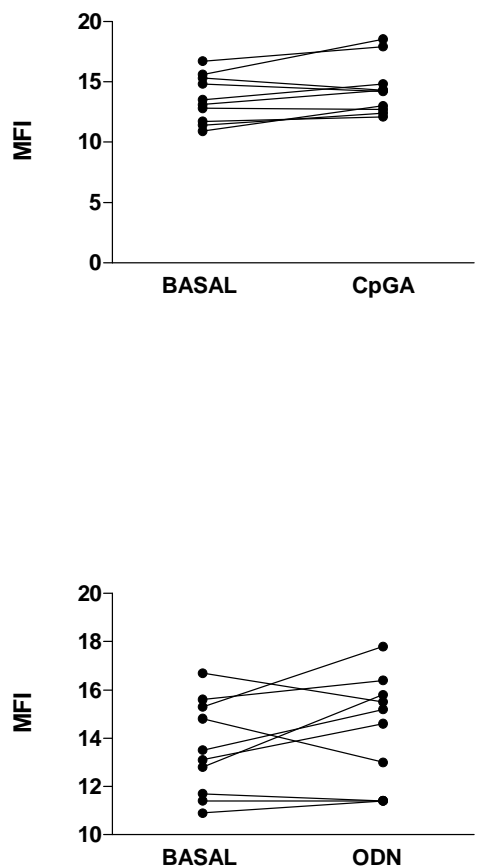

Figura 13. Expressão intracelular de STAT4 em CMN após estímulo in vitro com CpGA. Células mononucleares de indivíduos sadios $(n=10)$ e pacientes UCI $(\mathrm{N}=10)$ foram cultivadas na presença ou não de CpGA ou ODN $(2,0 \mu \mathrm{M})$ por $4 \mathrm{~h}$ e analisadas por citometria de fluxo, quanto a fosforilação de STAT4. Os resultados representam a intensidade média de fluorescência (MFI) da população positiva. ${ }^{*} \mathrm{P} \leq 0.05, * * \mathrm{P} \leq 0.01$ quando comparado ao basal. 
a)

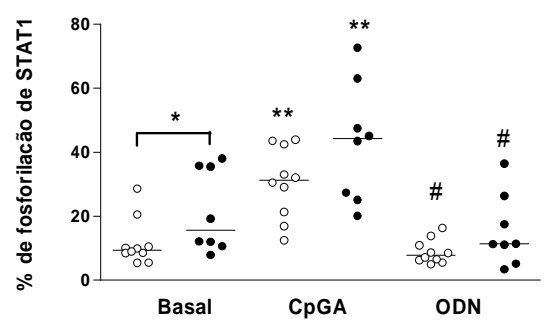

b)

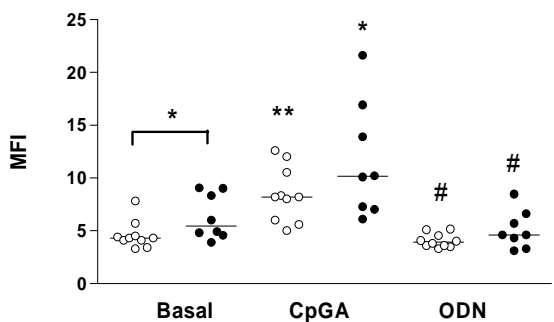

c)

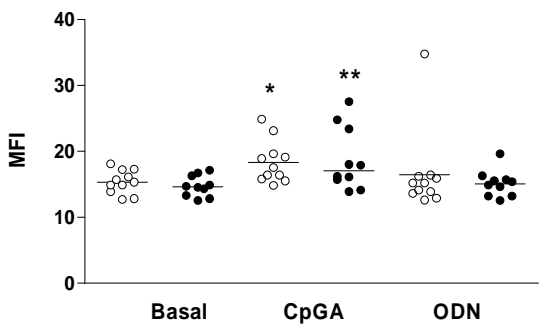

STAT4
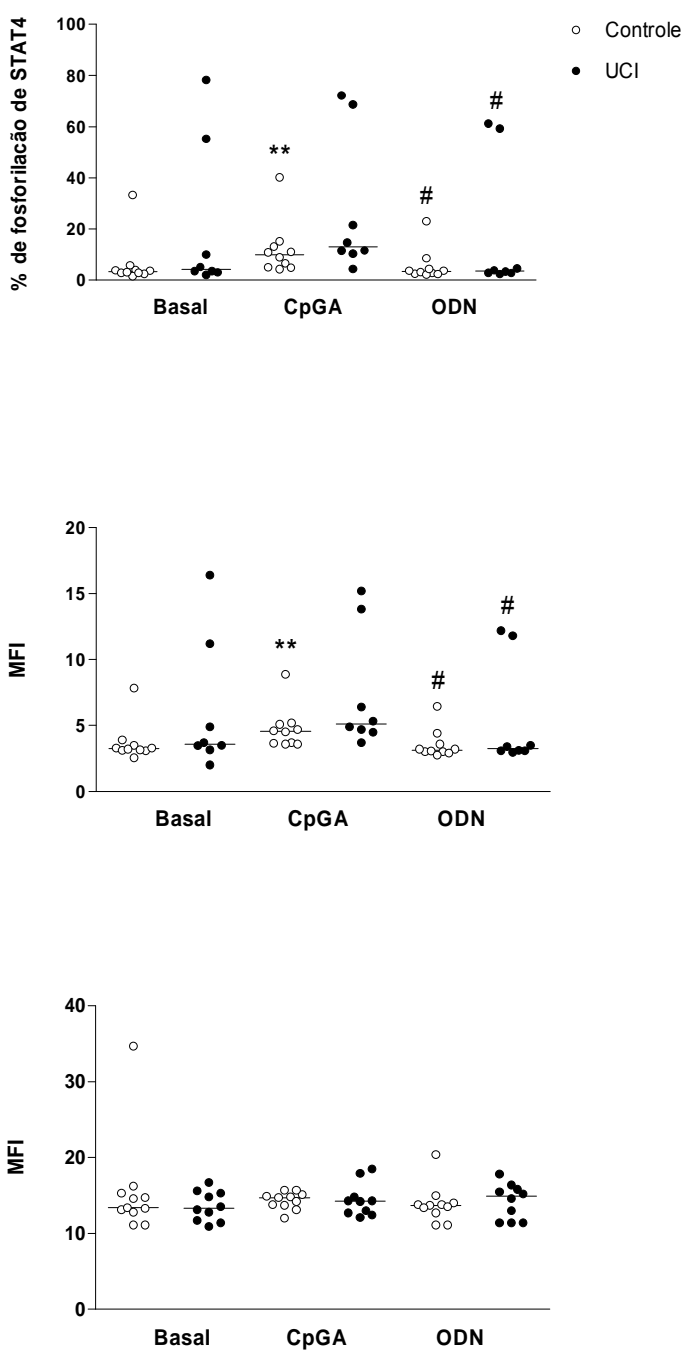

Figura 14. Expressão intracelular de STAT1 e STAT4 em CMN após estímulo in vitro com

CpGA. Células mononucleares foram cultivadas na presença de CpGA e ODN $(2,0 \mu \mathrm{M})$ por $4 \mathrm{~h}$ e analisadas por citometria de fluxo, quanto a fosforilação de STAT1 e STAT4. a) \% de fosforilação, indivíduos sadios $(n=10)$ e pacientes UCI $(N=8)$ b) MFI da população total de células mononucleares, indivíduos sadios $(\mathrm{n}=10)$ e pacientes UCI $(\mathrm{N}=8)$, c) MFI da população positiva, indivíduos sadios $(\mathrm{n}=11)$ e pacientes UCI $(\mathrm{N}=10)$. $* \mathrm{P} \leq 0.05, * * \mathrm{P} \leq 0.01$ quando comparado ao basal, \# quando comparado ao estímulo com CpGA. 


\section{Quantificação de pDCs em sangue periférico de indivíduos normais e pacientes com UCI.}

Numerosos estudos têm demonstrado que as células dendríticas plasmocitóides humanas são as principais produtoras de IFN- $\alpha$ em resposta às sequências de DNA via TLR9 (KLINMAN et al., 1996; SPARWASSER et al., 1998; SIEGAL et al., 1999). Para verificar se a diminuída produção de IFN- $\alpha$, induzida por CpGA (Fig 3b) nos pacientes com UCI, está relacionada à uma diminuição no número de células dendríticas plasmocitóides circulantes, foi realizada a quantificação de pDCs em sangue periférico de indivíduos normais e pacientes com UCI.

A quantificação de pDCs foi determinada por citometria de fluxo a partir de uma região delimitando a população de linfócitos e monócitos como pode se observar no histograma de citometria composto por tamanho e granulosidade das células (Fig 15a). A seguir as células foram marcadas com anticorpos anti-CD304 (BDCA-4) PE e antiCD123 PC5 e consideradas como pDCs (Fig 15a).

A figura $15 \mathrm{~b}$ mostra que a frequência encontrada no sangue periférico de indivíduos saudáveis é de 0,4 à $0,8 \%$. Não houve diferença entre as porcentagens de pDCs de pacientes com UCI e dos indivíduos controles.

Os resultados mostram que na UCI, a baixa resposta ao agonista de TLR9, não é conseqüente à diminuição percentual de células dendríticas plasmocitóides no sangue periférico. 
a)
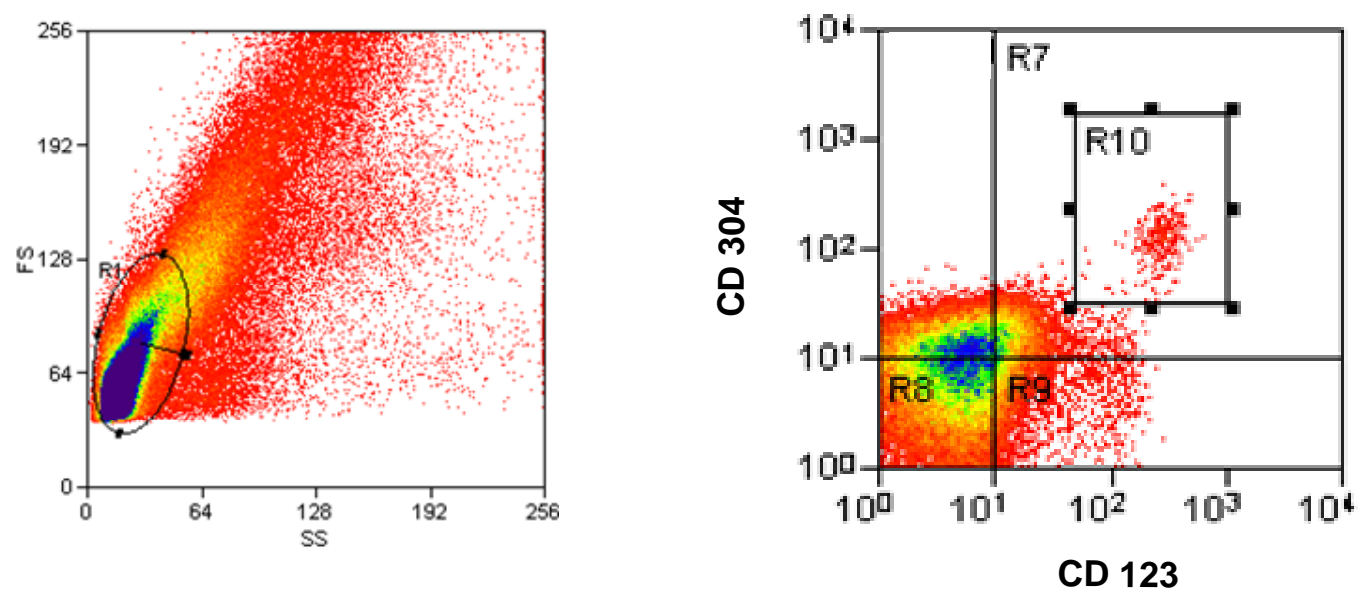

b)

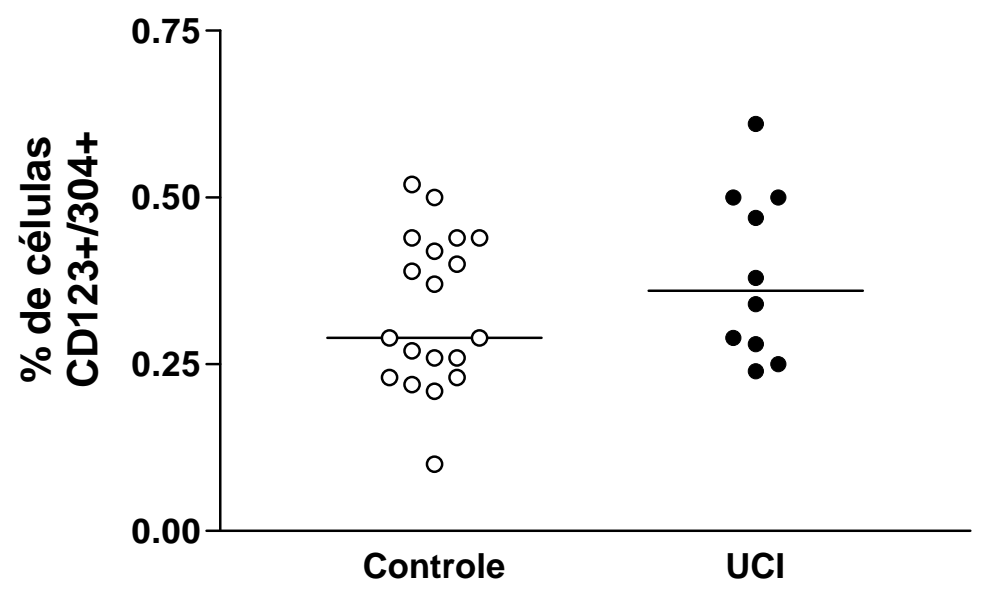

Figura 15. Quantificação de pDCs em sangue periférico de pacientes com Urticária Crônica Idiopática. O histograma ilustra a porcentagem de células CD304+/123+ (R10) de um indivíduo controle, avaliados por citometria de fluxo (a). Quantificação de pDC do sangue periférico do grupo controle (Controle, $n=18$ ) e de pacientes (UCI, $n=$ 10), realizado por citometria de fluxo. 


\section{Análise da expressão dos marcadores de ativação/co-estimulatórias em pDCs após estímulo in vitro com CpGA.}

Considerando que as pDCs são as principais produtoras de IFN- $\alpha$, foi avaliado se a capacidade de ativação das pDC de pacientes com UCI na resposta ao agonista de TLR9 poderia estar relacionada com a baixa produção de IFN- $\alpha$. Para tal, foram realizadas culturas com $\mathrm{CMN}$ estimuladas com $\mathrm{CpGA}(2,0 \mu \mathrm{M})$ por 24 horas e a expressão das moléculas de CD40, CD80 e CD86 foram avaliadas em pDCs. As pDCs foram caracterizadas como células Lin-/CD123+ por citometria de fluxo e avaliadas quanto ao percentual de expressão, MFI da população total de células Lin-/CD123+ e MFI da população de positiva.

A Figura 16 mostra os histogramas obtidos com a expressão de CD40, CD80 e CD86 das pDCs, de um indivíduo saudável, na condição basal e após estímulo com CpGA.

Ao avaliarmos o percentual de pDCs que expressam CD40 após estímulo com CpGA, observamos um aumento significativo em indivíduos sadios em comparação a situação basal (Figura 17a). Em contraste, no paciente UCI, o estímulo com CpGA não foi capaz de induzir aumento no percentual de expressão de CD40. Quanto a porcentagem basal de pDC CD80+ em relação ao controle, está aumentada, mas, sob estímulo aumenta para ambos (Figura 17b).

A média de intensidade de fluorescência da população total de pDCs e da população positiva mostrou resultados bastante semelhantes em relação a expressão de CD40 e CD80. Observamos que o estímulo com CpGA induziu um aumento significativo na MFI de CD40 e CD80 nos controles e nos pacientes quando comparado com a situação basal e com o ODN controle (Figura 18). Pequenas alterações foram 
observadas em relação à expressão de CD86. A MFI da população total de pDCs após estímulo com CpGA foi significativamente aumentada em controles e pacientes quando comparado com a situação basal mas, quando comparado com o ODN controle este aumento só foi observado no indivíduo saudável. Quando avaliamos a população positiva este aumento só foi observado no grupo de pacientes UCI (Figura 19). Embora não tenha sido observada diferença na expressão destes marcadores quando comparamos pacientes UCI com os indivíduos normais, observamos que o percentual de expressão de CD40 no paciente UCI não se altera após estímulo. Considerando que a expressão de CD40 é um importante marcador de maturação da pDC, este fato pode interferir na capacidade de ativação das pDCs. 

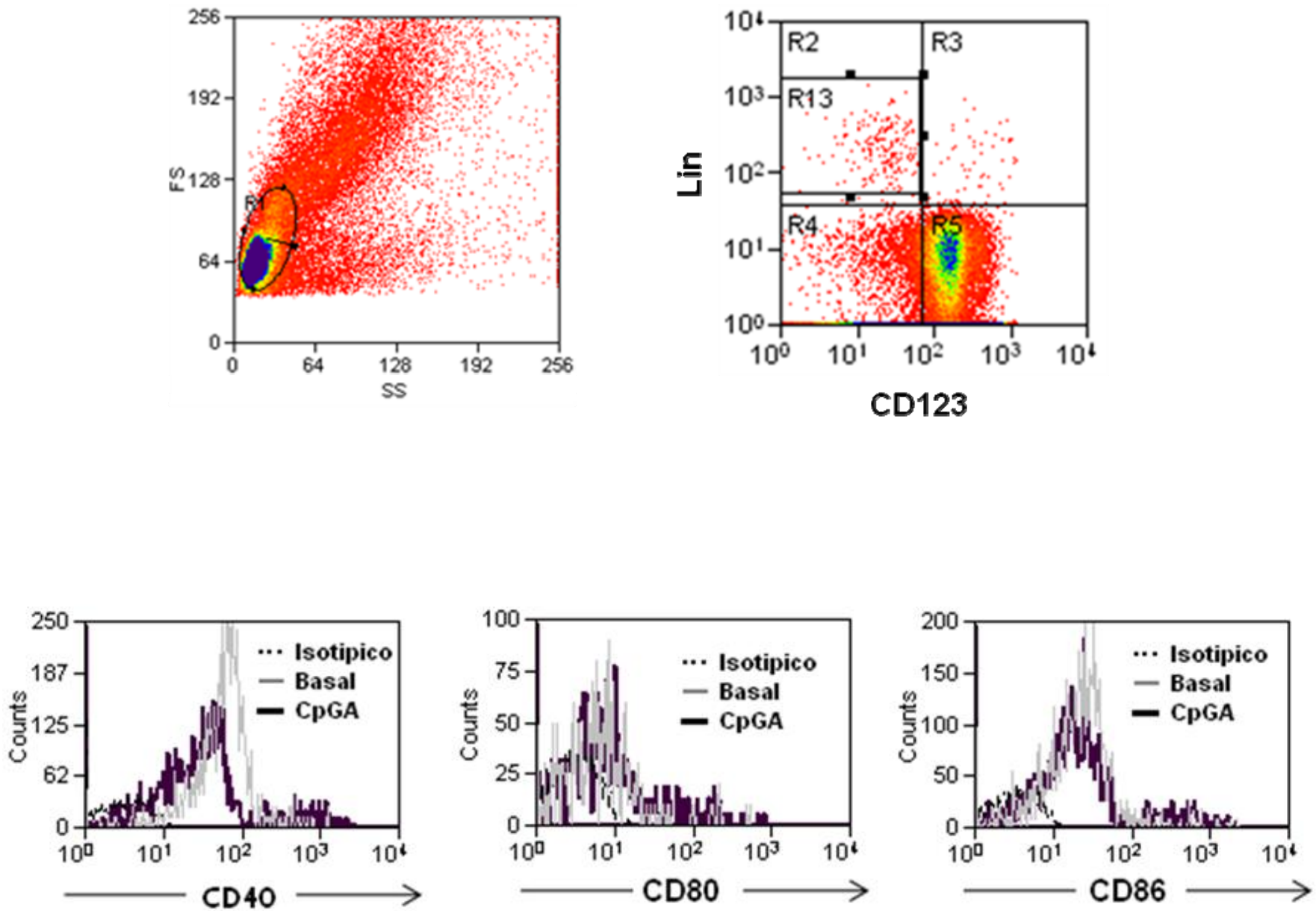

Figura 16. Histograma ilustrativo da expressão das moléculas CD40, CD80 e CD86 em pDC após estímulo in vitro com CpGA. Células mononucleares de um indivíduo saudável foram cultivadas na presença ou não de CpGA $(2,0 \mu \mathrm{M})$ por $24 \mathrm{~h}$ e analisadas por citometria de fluxo, quanto a expressão de CD40, CD80, CD86 em células Lin-/123+. A figura mostra os histogramas representativos de um experimento. 
a) CD40

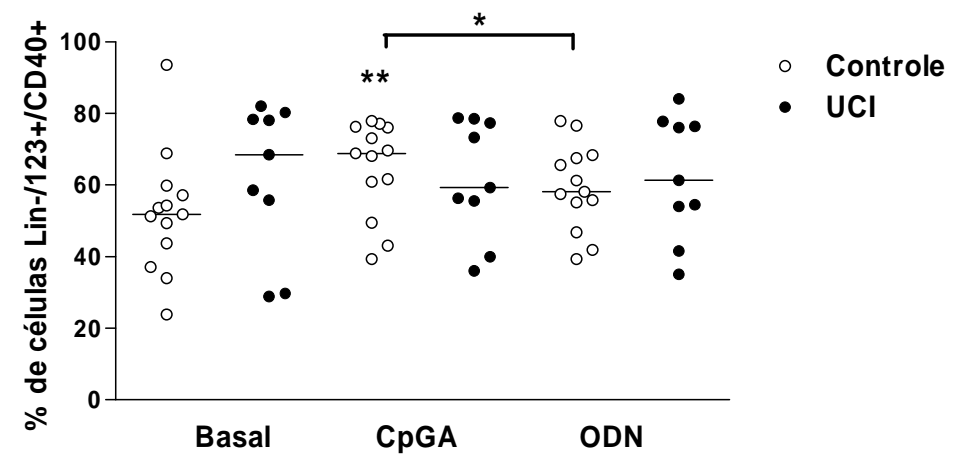

b) CD80

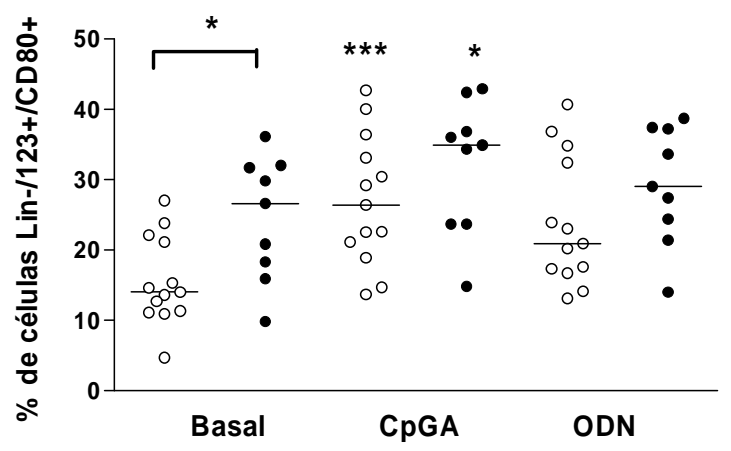

c) CD86

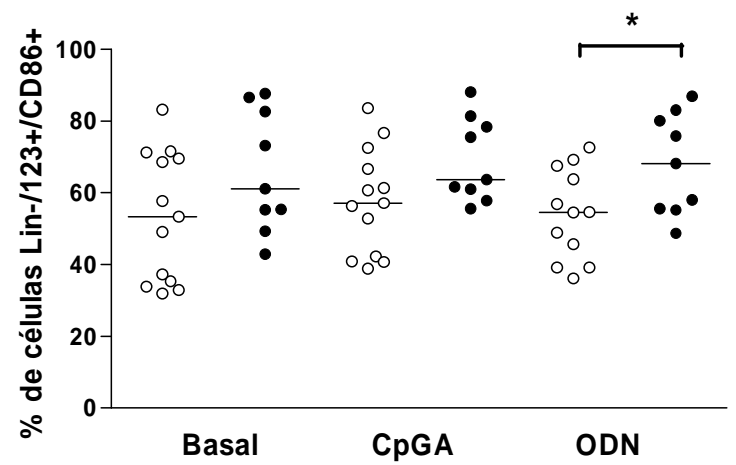

Figura 17. Expressão das moléculas CD40, CD80 e CD86 em pDCs após estímulo in vitro com CpGA. Células mononucleares foram cultivadas na presença de CpGA ou ODN $(2,0 \mu \mathrm{M})$ por $24 \mathrm{~h}$ e analisadas por citometria de fluxo. Os resultados representam o percentual de expressão de CD40, CD80 e CD86 de células Lin-/123+e a linha horizontal representa a mediana dos grupos. a) \% CD40, indivíduos sadios $(\mathrm{n}=12)$ e pacientes UCI $(\mathrm{N}=9), \mathrm{b}) \% \mathrm{CD} 80$, indivíduos sadios $(\mathrm{n}=13)$ e pacientes UCI $(\mathrm{n}=9)$, c) \% CD86, indivíduos sadios $(\mathrm{n}=13)$ e pacientes UCI $(\mathrm{n}=9), * \mathrm{P} \leq 0.05$, $* * \mathrm{P} \leq 0.01, * * * \mathrm{P} \leq 0.001$, quando comparado com o basal. 
a) CD40

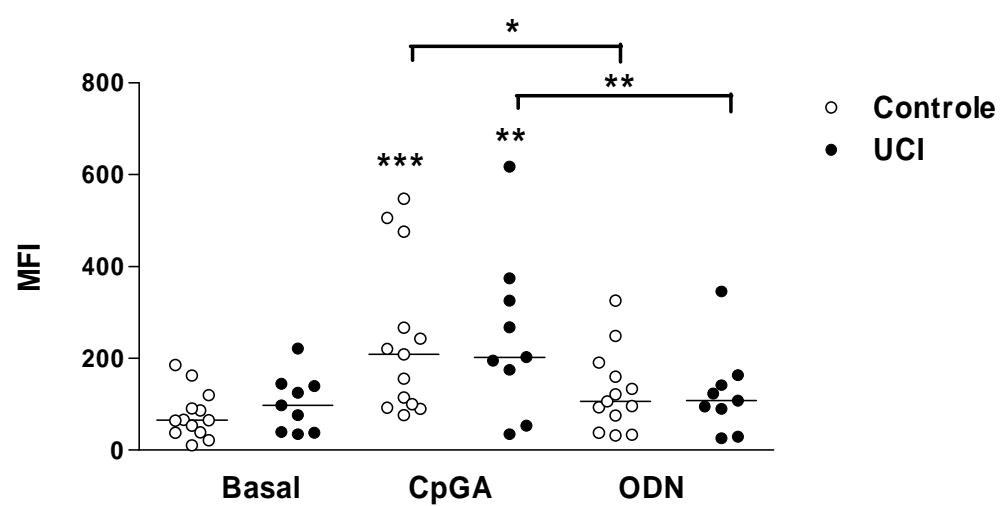

b) $\mathrm{CD} 80$

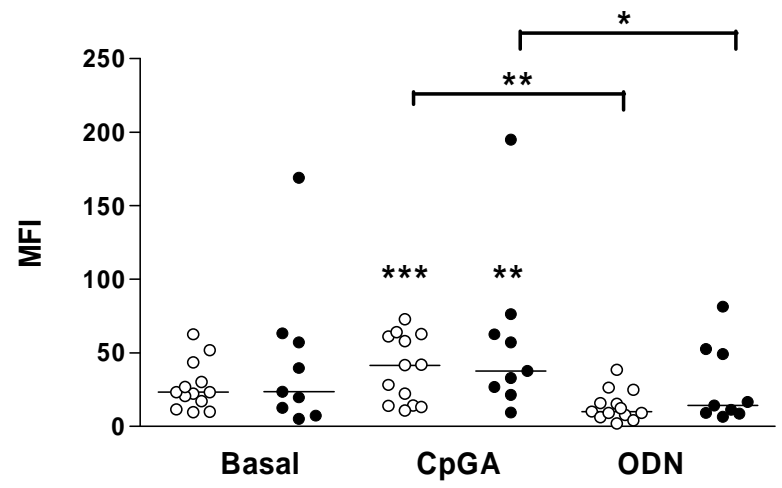

c) CD86

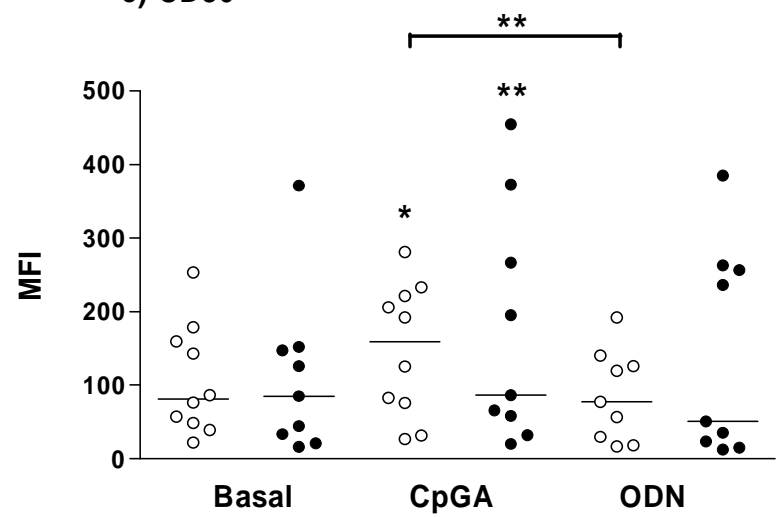

Figura 18. Expressão das moléculas CD40, CD80 e CD86 em pDCs após estímulo in vitro com CpGA. Células mononucleares foram cultivadas na presença de CpGA ou ODN $(2,0 \mu \mathrm{M})$ por $24 \mathrm{~h}$ e analisadas por citometria de fluxo. Os resultados representam a intensidade média de fluorescência (MFI) de células Lin-/123+ e a linha horizontal representa a mediana dos grupos. a) CD40, indivíduos sadios $(n=13)$ e pacientes UCI $(\mathrm{N}=9)$, b) CD80, indivíduos sadios ( $\mathrm{n}=13)$ e pacientes UCI ( $\mathrm{n}=9)$, c) \% CD86, indivíduos sadios $(\mathrm{n}=10)$ e pacientes UCI $(\mathrm{n}=9),{ }^{*} \mathrm{P} \leq 0.05, * * \mathrm{P} \leq 0.01, * * * \mathrm{P} \leq 0.001$ quando comparado com o basal. 
a) CD40

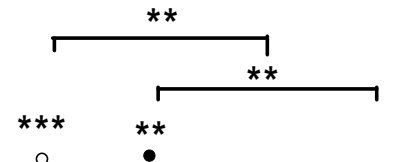

Controle

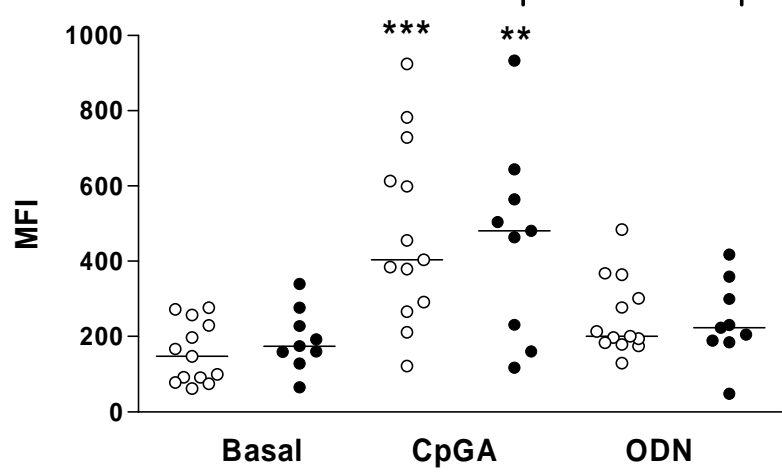

- $\mathrm{UCl}$

b) $\mathrm{CD} 80$

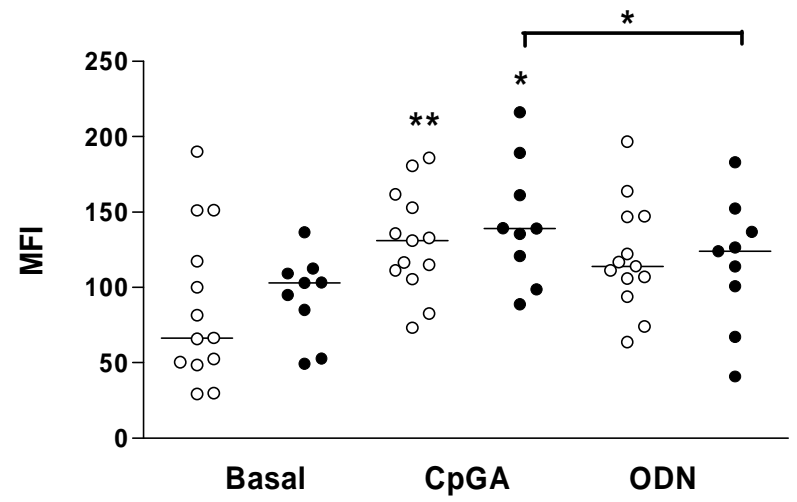

c) CD86

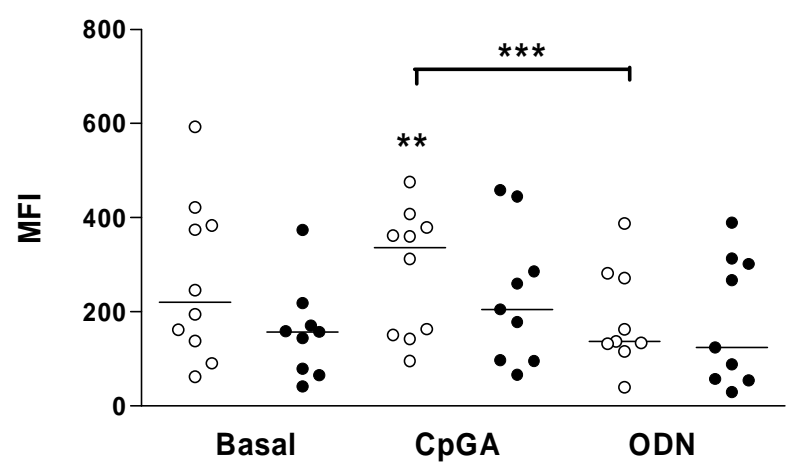

Figura 19. Expressão das moléculas CD40, CD80 e CD86 em pDCs após estímulo in vitro com CpGA. Células mononucleares foram cultivadas na presença de CpGA ou ODN $(2,0 \mu \mathrm{M})$ por $24 \mathrm{~h}$ e analisadas por citometria de fluxo. Os resultados representam a intensidade média de fluorescência (MFI) da população positiva e a linha horizontal representa a mediana dos grupos. a) CD40, indivíduos sadios ( $\mathrm{n}=13)$ e pacientes UCI $(\mathrm{n}=9)$, b) CD80, indivíduos sadios $(\mathrm{n}=13)$ e pacientes UCI $(\mathrm{n}=9), \mathrm{c}) \%$ CD86, indivíduos sadios $(\mathrm{n}=10)$ e pacientes UCI $(\mathrm{n}=9), * \mathrm{P} \leq 0.05$, $* * \mathrm{P} \leq 0.01, * * * \mathrm{P} \leq 0.001$ quando comparado com o basal. 


\section{Percentual de pDCs secretores de IFN- $\alpha$ após estímulo in vitro com CpGA.}

Continuando a investigação para avaliar a baixa capacidade de produção de IFN$\alpha$ em resposta ao agonista de TLR9, o CpGA, e averiguar o subtipo celular produtor da citocina, avaliamos a expressão intracelular de IFN- $\alpha$. Células mononucleares foram cultivadas em presença CpGA por 24 horas e após 5 horas de estímulo foi adicionada a brefeldina A, um inibidor da secreção da citocina. A expressão intracelular de IFN- $\alpha$ em células Lin-/123+ foi avaliada por citometria de fluxo.

A Figura 20 mostra os histogramas obtidos com a expressão intracelular de IFN$\alpha$ de um indivíduo saudável, na condição basal e após estímulo com CpGA.

Observamos que após estímulo com CpGA houve um significativo aumento na expressão intracelular de IFN- $\alpha$ em pDCs de pacientes e controles em comparação à situação basal (Figura 21). Os resultados também mostraram uma significativa diminuição na porcentagem de pDC IFN- $\alpha+$ em pacientes com UCI quando comparados com indivíduos controles (Fig. 21a). Quando avaliamos a média de intensidade de fluorescência na população total de células Lin-/123+ e na população positiva não foi observada diferença entre os grupos.

Estes dados confirmam os resultados prévios em leucócitos que evidenciaram diminuída capacidade secreção de IFN- $\alpha$ dos pacientes com UCI após estímulo com CpGA, mostrando que há uma alteração na sinalização para a produção de IFN- $\alpha$ na UCI. Os resultados evidenciam que na UCI, não há alteração do percentual das pDCs no sangue periférico, e que ativação via TLR9 induz expressão de moléculas coestimulatórias, mas baixa capacidade secretória de IFN- $\alpha$. 

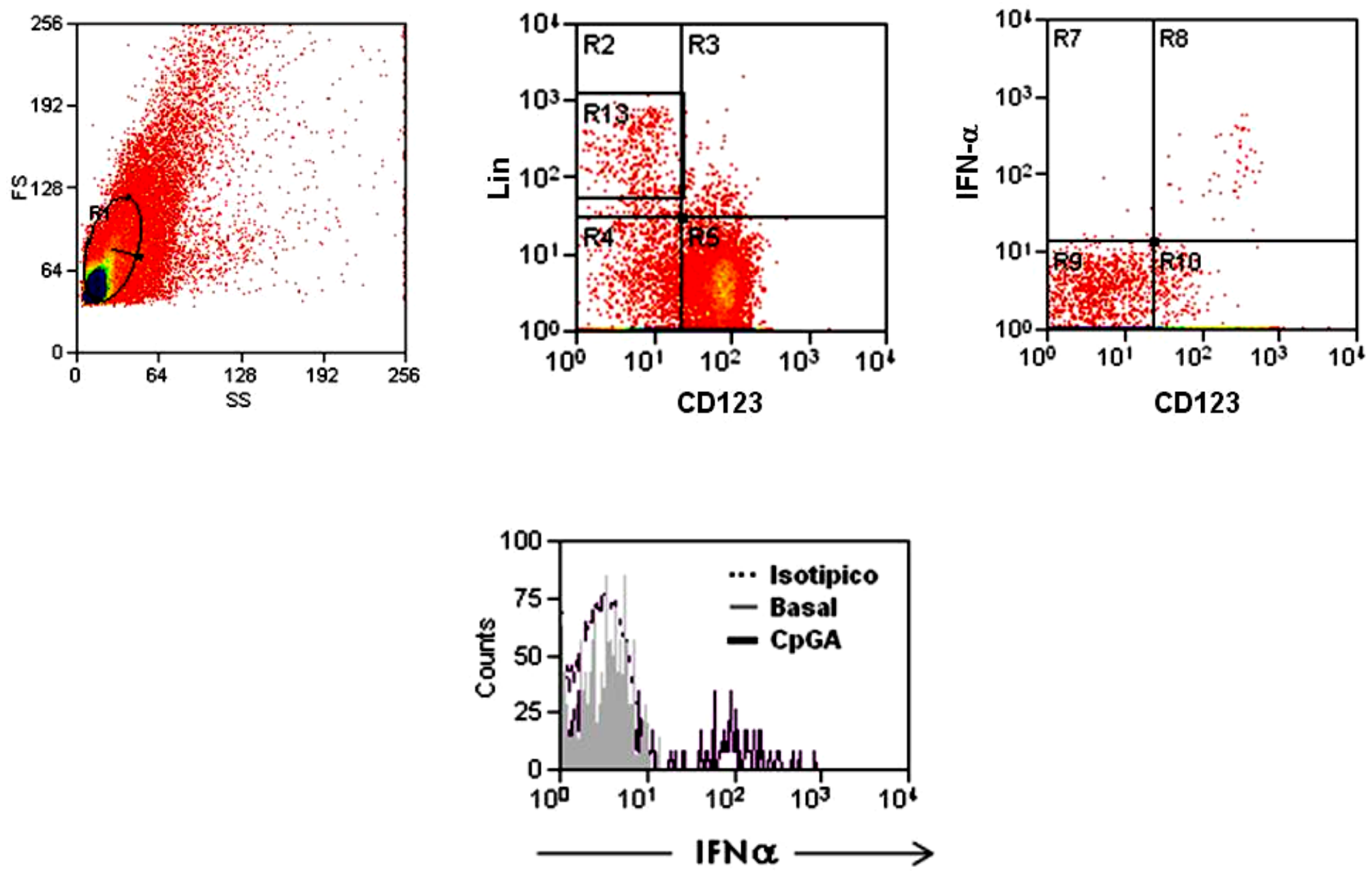

Figura 20. Histograma ilustrativo da expressão intracelular de IFNa em pDC após estímulo in vitro com CpGA. Células mononucleares de um indivíduo saudável foram cultivadas na presença ou não de $\operatorname{CpGA}(2,0 \mu \mathrm{M})$ por $24 \mathrm{~h}$ e a brefeldina foi adicionada após 5 horas de estímulo e analisadas por citometria de fluxo. A figura mostra os histogramas representativos de um experimento. 
a)

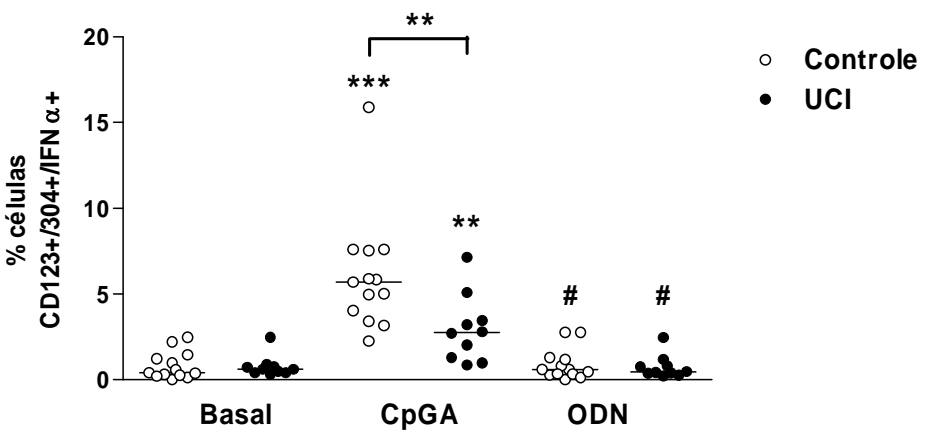

b)

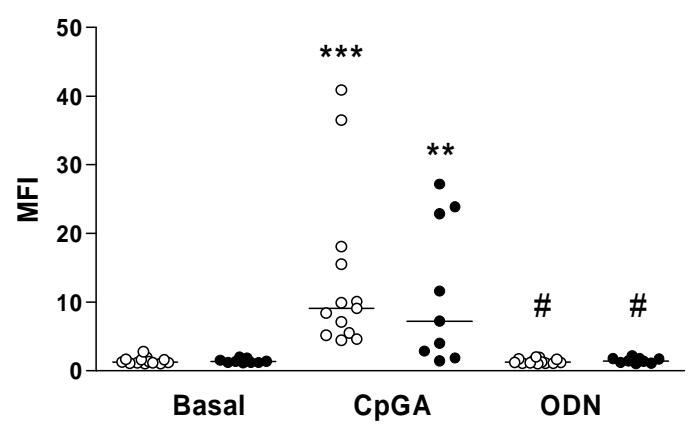

c)

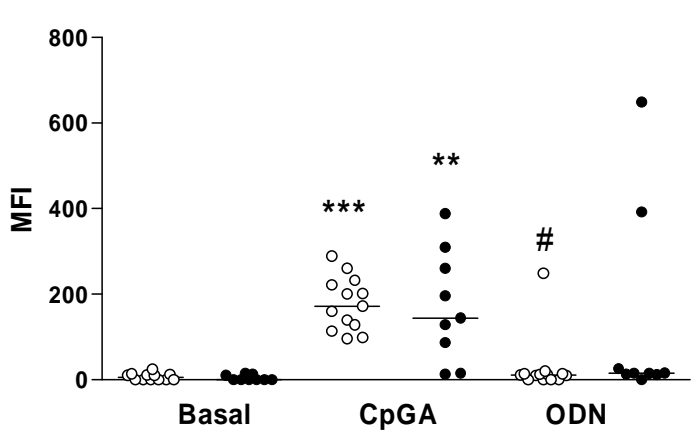

Figura 21. Expressão intracelular de IFN- $\alpha$ pDCs após estímulo in vitro com CpGA. Células mononucleares foram cultivadas na presença de CpGA ou ODN $(2,0 \mu \mathrm{M})$ por $24 \mathrm{~h}$ e a brefeldina foi adicionada após 5 horas de estímulo, posteriormente as células foram analisadas por citometria de fluxo. a) percentual de expressão intracelular de IFN- $\alpha$ em células Lin-/123+, indivíduos sadios $(n=13)$ e pacientes $\operatorname{UCI}(n=10)$, b) MFI da população total de pDCs, indivíduos sadios $(n=13)$ e pacientes UCI $(n=9)$, c) MFI da população positiva, indivíduos sadios $(\mathrm{n}=13)$ e pacientes UCI $(\mathrm{n}=9)$, A linha horizontal representa a mediana dos grupos. ${ }^{*} \mathrm{P}$ $\leq 0.05, * * \mathrm{P} \leq 0.01, * * * \mathrm{P} \leq 0.001$ quando comparado ao basal, \# quando comparado ao estimulado com CpGA. 


\section{Expressão de mRNA para TLR9 e IRF-7 em pacientes UCI.}

Para avaliar se a diminuição na produção de IFN- $\alpha$ estaria relacionada a ativação via TLR-9 foi avaliada em PBMCs de pacientes UCI a expressão do mRNA para TLR9 e IRF-7 após 8 horas e 24 horas de estímulo com CpGA. A figura 22 mostra uma significativa diminuição de mRNA pata TLR9 em pacientes UCI após 8 horas de estímulo. Este efeito é transitório uma vez que após 24 horas esta diminuição não é mais observada ao compararmos os grupos. Quanto à expressão de mRNA para IRF-7 foi observado um aumento após estímulo com CpGA nos indivíduos normais, efeito não observado em pacientes UCI. Estes resultados mostram que nos pacientes UCI há uma freqüência normal de pDCs no sangue periférico com diminuição da expressão intracelular de IFN- $\alpha$ após ativação com CpGA associada com uma transitória regulação negativa de IFN- $\alpha$. 

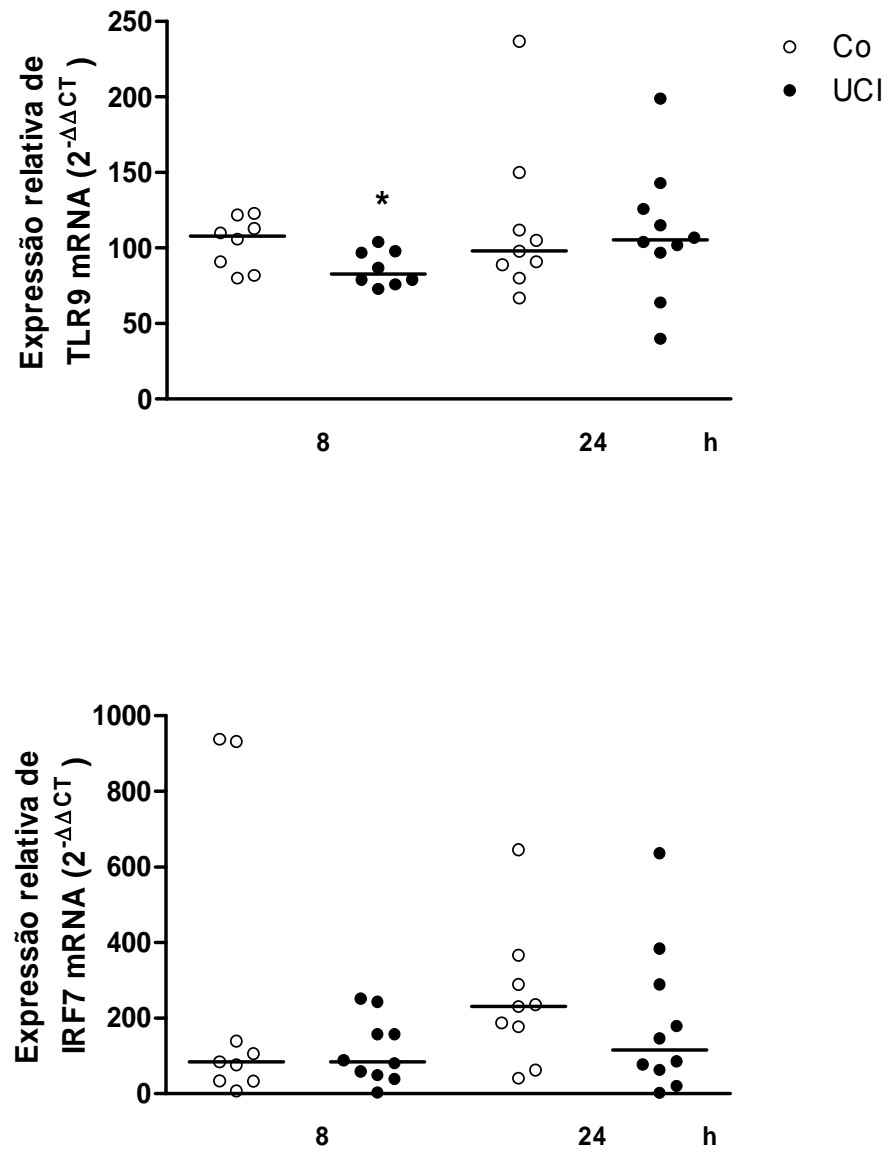

Figura 22. Efeito do CpGA na expressão relativa de mRNA de TLR9 e IFR-7. Células mononucleares foram cultivadas na presença ou não de CpGA $(2,0 \mu \mathrm{M})$ por 8 e $24 \mathrm{~h}$ e a expressão de mRNA foi quantificada por real time- PCR. A linha horizontal representa a mediana dos grupos. $* \mathrm{P} \leq 0.05$ quando comparado com o indivíduo saudável. 
10. Expressão de CD123 (pDC) em biópsias de pele de pacientes UCI.

Outra possibilidade para explicar a baixa capacidade de produção de IFN- $\alpha$ em resposta ao CpGA, seria averiguar a principal subtipo celular produtor da citocina, as pDCs, nas lesões de pele de UCI. Avaliamos a expressão de CD123 por imunoistoquímica em biópsia de pele lesionada de pacientes UCI. Foi realizada imunoistoquímica de 16 casos de UCI, controles positivos (Líquen Plano e Lúpus) e controles negativos da reação. Dos vários casos de UCI realizados $(n=16)$ apenas 5 puderam ser avaliados quanto a presença da pDC. Nos 5 casos de UCI observou-se um perfil semelhante, com pouco infiltrado inflamatório e presença de raras células CD123 positivas presentes ao longo do infiltrado. Casos adicionais serão realizados para verificarmos a possibilidade de quantificação das pDCs. Até o momento, devido ao baixo número de células CD123+ encontradas, a diminuição da produção de IFN- $\alpha$ em resposta ao CpGA observada nos pacientes UCI não parece estar relacionada à migração e conseqüente presença da pDC na lesão (Figura 23). Em contraste, há intensa presença de células CD123+ encontradas em casos de lúpus e líquen plano.
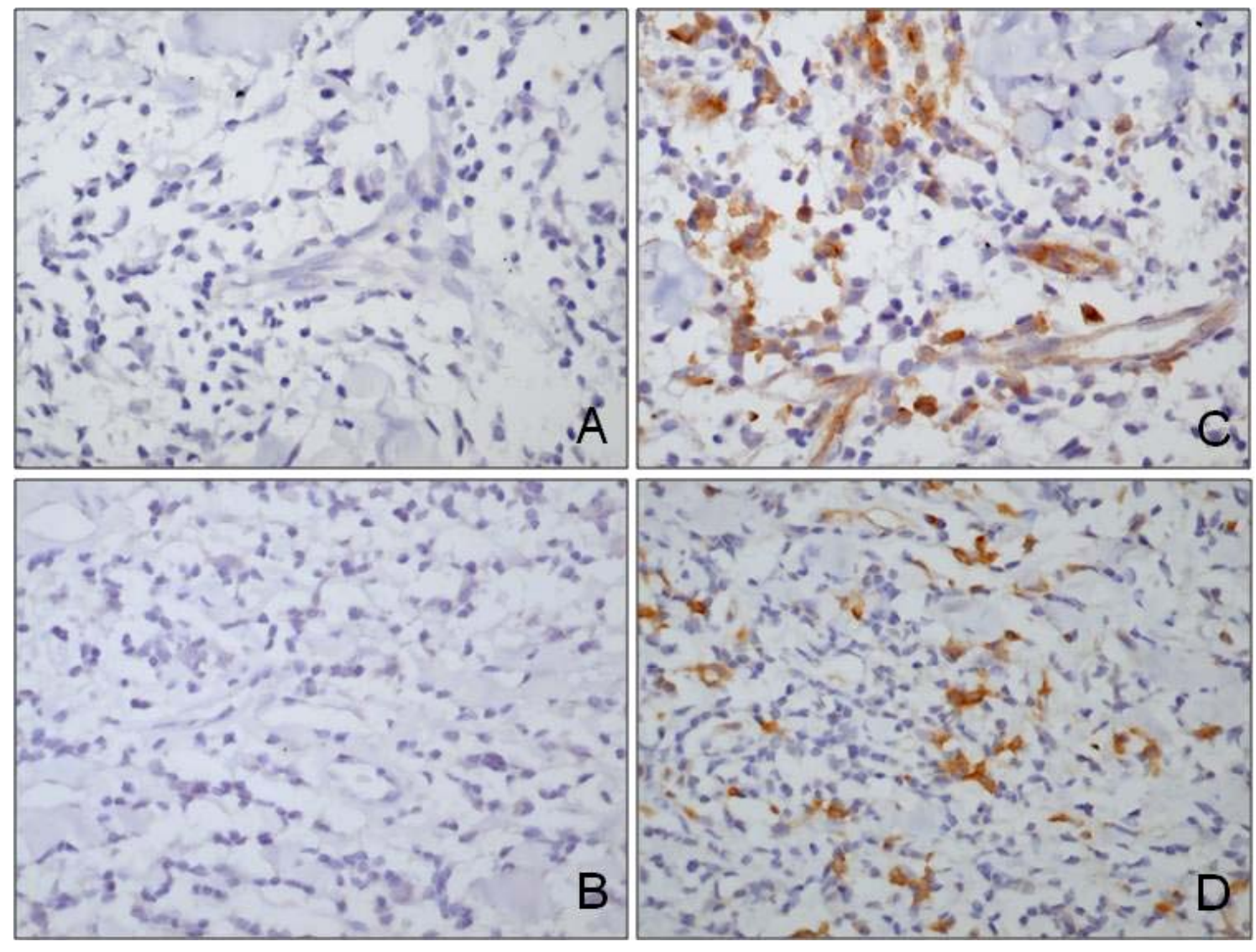

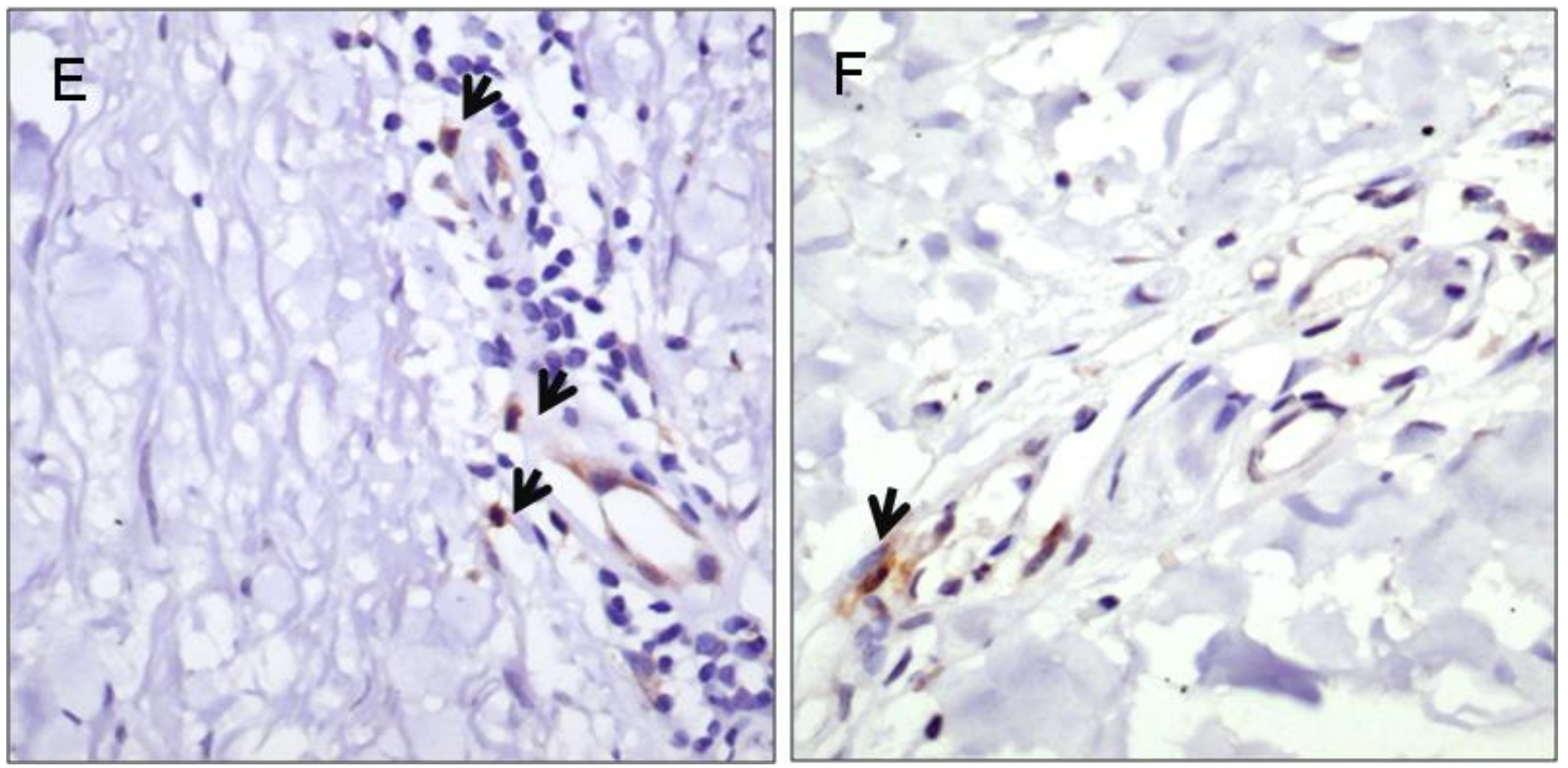

Figura 23. Células dendríticas plasmocitóides em lesões de pele na UCI. (A) Controle negativo Lúpus, (B) Controle negativo Líquen Plano, (C) Controle positivo Lúpus, (D) Controle positivo Líquen Plano, (E e F) Células CD123+ distribuídas no infiltrado inflamatório de lesões de pele UCI (aumento original de 400x). 


\section{DISCUSSÃO}

Uma das abordagens do projeto foi avaliar na UCI, o potencial de resposta inata, através da estimulação da via TLR9, utilizando como agonista oligodeoxinucleotídeos (ODNs) contendo motivos CpG ou, ODNs, que agem independente da via TLR9, mas que possuem capacidade supressora ao estímulo via TLR9. Inicialmente foi abordado o potencial de produção de citocinas em leucócitos do sangue periférico dos pacientes com UCI e indivíduos saudáveis em resposta aos CpG. Desta forma, considerando a inexistência de dados relacionados a imunomodulação da resposta inata na UCI, o CpG tipo A foi estudado como agonista do TLR9 e o ODN-supressor para verificar sua ação inibitória na produção de citocinas induzida pelo CpGA.

Nos pacientes com UCI, foi verificado que o CpGA induziu uma baixa secreção de IL-10 e níveis quase indetectáveis de IFN- $\alpha$ comparados aos indivíduos controles. O CpGA têm sido citado por sua capacidade de estimular as pDCs humanas a secretar altos níveis de IFN- $\alpha$ (Krug et al., 2001). Uma das razões para a eficiente resposta das pDCs nas infecções e doenças auto-imunes é que estas células expressam constitutivamente o TLR7 que reconhece ácidos nucléicos virais (simples fita de RNA) e o TLR9 (Kadowaki et al., 2001). O IFN- $\alpha$ é um fator que exerce potente atividade antiviral, inibindo a replicação e bloqueando a disseminação do vírus (Biron, 2001). A manifestação de urticária de caráter crônico é relatada com freqüência em estágios de infecção viral como no caso das hepatites (Cribier, 2006). Ainda não se sabe se na UCI, há mais suscetibilidade às infecções virais devido à baixa produção de IFN $\alpha$, contudo, foram detectados 2 casos de hepatite $\mathrm{C}$ nos pacientes com UCI analisados $(n=22)$. O papel dos agentes infecciosos como causadores de UCI não é claro mas, recentemente 
foram relatados dois casos de infecção genital por Herpes simplex e exarcebação da UCI (Zawar et al., 2009).

A secreção de IFN- $\alpha$ foi quase indetectável na maioria dos pacientes com UCI, o que enfatiza a necessidade de verificar o potencial de resposta de IFN- $\alpha$, por outras vias de ativação, para detectar se esta alteração é decorrente da sinalização via TLR-9.

A secreção de IL-10 em resposta ao CpGA também foi diminuída nos pacientes UCI, salientando a existência de alteração na sua via de sinalização, seja quanto aos níveis constitutivos ou induzidos via TLR. Previamente, verificamos que na UCI, há uma significante diminuição na expressão ex vivo de mRNA para IL-10 pelas CMN, apesar de que, em resposta ao estímulo, os pacientes com ASST positivo mostram aumento de secreção desta citocina (Dos Santos et al., 2008), o que sugere um distúrbio da IL-10 nesta doença. Esta citocina possui um importante efeito modulatório, capaz de diminuir a produção de IFN- $\alpha$ e IL-12 pelas pDCs estimulado por CD40L juntamente com CpG (Duramad et al., 2003). Entretanto, a IL-10, não parece estar relacionada à diminuição de IFN- $\alpha$ e de IL-12 nos pacientes com UCI, considerando que seus níveis estão significantemente diminuídos em relação aos controles.

Diferente do CpGA, o ODN-S não é expresso em células B e pDCs humanas, considerando que não é agonista do TLR9 (Lau et al., 2005) e ainda não foi determinado qual o subtipo celular envolvido. O ODN-S exerce sua função tanto em camundongos selvagens como nos geneticamente deficientes de TLR9 (Lau et al., 2005). Além disto, o ODN-S possui capacidade estimulatória, capaz de estimular a produção in vitro de IL-12p40 pelos leucócitos, embora a secreção desta citocina na menor molaridade testada do ODN-S $(0.25 \mu \mathrm{M})$ foi significantemente diminuída nos pacientes em relação aos indivíduos normais. Mais uma vez, a baixa capacidade de produção de IL-12p40 dos leucócitos de pacientes com UCI, sugere algum 
comprometimento na habilidade de desenvolver a resposta inata, que não seja via TLR9, uma vez que o ODN-S não sinaliza via TLR9. Entretanto, para possibilitar uma ampla participação das células em resposta ao ODN S foram utilizados leucócitos, assim, ainda é preciso avaliar qual a população celular comprometida.

A IL-12 é uma citocina que induz a produção de IFN- $\gamma$ e consequentemente a indução de respostas Th1. Como pacientes com UC mostraram diminuição na secreção de IL-12p40, será interessante avaliar a produção de IFN- $\gamma$ nos pacientes com UCI, considerando que há controvérsias quanto à sua produção na UC (Ferrer et al., 2002, Confino-Cohen et al., 2004). Entretanto, em nosso grupo avaliamos que a produção de IFN- $\alpha$ induzida por mitógeno de células T, PHA, nos pacientes com UCI é similar ao grupo saudável, sem tendências de produção de citocinas Th1/Th2, mas mostrando um desequilíbrio de produção de IL-2, IL-10 e IL-17a (Dos Santos et al., 2008).

O potencial inibitório do ODN-S na produção de citocinas induzida pelo CpGA, foi observado tanto pelas células de pacientes como de controles na secreção de IL-10, e de IFN- $\alpha$. A produção de IFN- $\alpha$ nos pacientes com UCI, que já era quase indetectável após estímulo com CpGA, foi eficazmente inibida pelo ODN S. A capacidade inibitória do ODN S na produção de IFN- $\alpha$ induzido por CpGA de CMN de indivíduos sadios já foi descrita anteriormente (Lenert et al., 2005). O uso terapêutico do ODN S em modelos experimentais de doenças autoimunes, como o lúpus e a encefalomielite autoimune têm relatado diminuição dos sintomas clínicos da doença (Ho et al. 2003; Lenert 2005).

A utilização de ODN contendo seqüências G mostrou ser capaz de inibir a secreção in vitro de TNF- $\alpha$ em linhagem de macrófagos, além de suprimir a produção de IFN- $\alpha$ por pDCs e abolir a indução de mRNA para várias espécies de IFN- $\alpha$, inibindo a fosforilação da p38 (Mirjam et al., 2007). A administração in vivo do ODNG 
em camundongos suprimiu os níveis de IL12p40 e TNF- $\alpha$ séricos induzidos pelo CpGA (Mirjam et al., 2007). Berghofer e colaboradores (2007) mostraram que a coestimulação simultânea com agonistas de TLR7 e TLR9 (ODN 2006) foi capaz de inibir a produção de IFN- $\alpha$ em pDCs purificadas, resultando em aumento de IL-8 e expressão de CD40, um importante marcador de maturação da pDC. Os resultados evidenciaram maior efeito inibitório com a co-estimulação das vias TLR7/TLR9 na secreção de IFN- $\alpha$ induzido por CpGA, do que com a mono-estimulação via TLR7, sugerindo ser um novo tipo de inibidor de TLR9.

Diferentes modelos de ODNs têm sido estudados na tentativa de encontrar uma seqüência de oligonucleotídeos capaz de prevenir ou reverter os efeitos das doenças autoimunes (Hückel et al., 2006, Dajee et al., 2006). Neste sentido, estudos in vitro são importantes para compreender o potencial imunomodulatório de ODN sintéticos em doenças inflamatórias e/ou autoimune. Há duas classes distintas de ODNs supressores, uma delas, contêm padrões poli(G) e é caracterizado por sua capacidade de modular a ativação antígeno específica e policlonal independente da interação via TLR9 (Ho et al., 2003, Shirota et al., 2004). Alguns estudos demonstraram que este ODN supressor inibe a ativação de STAT1 dependente de IFN- $\gamma$ com conseqüente aumento de expressão de T-bet. Outra classe de ODN supressor é composto por DNA rico em CG e inibe a ativação induzida pelo CpG (Ho et al., 2003; Krieg et al., 1998), interferindo em sua interação com o TLR9, inibindo a ativação dependente das vias NF-kB e AP-1 (Lenert et al., 2001). Entretanto, este $\mathrm{CpG}$ não bloqueia outras formas de ativação imune, ou seja, não inibem as cascatas de sinalização de IFN- $\gamma$ e IL-12. Este tipo de CpG supressor é o que foi adotado em nossos estudos in vitro para inibir a ativação via CpGA, e o que permitiu avaliar que nos pacientes com UCI, há uma diminuição de produção de IL-12p40 em resposta ao ODN-S. 
A interação dos Intérferons do tipo I com o IFNR presente na superfície celular fosforila os fatores STAT1 e STAT2 formando o complexo ISGF3, que uma vez translocado para o núcleo inicia a transcrição de genes para a produção de IFN- $\alpha$ (Platanias et al., 2005). Foi demonstrado que os CpGs imunomodulatórios podem afetar a ativação das células Th1 bloqueando a fosforilação de STAT1, 3 e 4 (Shirota et al., 2004). Cheng e colaboradores obtiveram resultado semelhante em camundongos, demonstrando que a utilização do ODNA 151 foi capaz de inibir a fosforilação de STAT1, STAT4 e a expressão de T-bet, modulando a resposta e prevenindo a arteriosclerose (Cheng et al., 2008). Assim, a baixa produção de IFN- $\alpha$ por pacientes UCI e a capacidade inibitória da ativação de STAT1 de alguns ODNs (Dong et al., 2004; Ho et al., 2003, Shirota et al., 2004), nos levou a investigar a fosforilação de STAT1 e STAT4 após estímulo com CpGA nos pacientes com UCI.

O estímulo com CpGA leva a uma fosforilação de STAT1 nos pacientes UCI semelhante aos indivíduos sadios, entretanto, foi observado um aumento no percentual de fosforilação de STAT1 em pacientes UCI na condição basal. É possível que este aumento basal seja um efeito secundário do uso de anti-histamínicos, uma droga de uso regular para todos os pacientes. Tem sido descrito que a histamina ou que o antagonista do receptor H4 (clobenpropit) leva a uma significativa supressão da fosforilação de STAT1 $\alpha$ no grupo não atópico após estímulo com PHA. Em contraste, antagonistas do receptor H4 podem potencializar a fosforilação de STAT1 (Wollenberg et al., 2002). Quanto a fosforilação de STAT4, o estímulo com CpGA só foi capaz de induzir a fosforilação de STAT4 nas células mononucleares de indivíduos saudáveis. O STAT4 classicamente não é considerado como fator envolvido na via de sinalização para IFN- $\alpha$ mas, ele interage com a parte citoplasmática do IFNR e está fortemente associado com o lupus (Kariuki et al., 2009). Nos pacientes com lupus há uma correlação positiva entre o 
genótipo de STAT4 (maior sensibilidade ao IFN- $\alpha$ ) com a gravidade da doença (Taylor et al., 2008). Ao contrário do que ocorre no lupus, na UCI, a falta de fosforilação de STAT4, em resposta ao CpGA pode contribuir para a diminuição na produção de IFN- $\alpha$ por uma via independente do reconhecimento via TLR9.

Outra abordagem do projeto foi avaliar a participação direta das pDCs para melhor compreender a baixa produção de IFN- $\alpha$ nos pacientes com UCI após estimulação com CpGA. As pDCs são consideradas produtoras profissionais de IFNs do tipo I, sendo que pDCs humanas após 24 horas de estímulo são capazes de produzir 200-1000 vezes mais IFNs que qualquer outro tipo celular (Siegal et al., 1999). Uma das possibilidades para explicar a diminuída produção de IFN- $\alpha$ nos pacientes UCI seria que o número de pDCs poderia estar diminuído nestes pacientes. Assim, foi realizada a quantificação de pDCs em sangue periférico por citometria de fluxo. Observamos uma média de $0,33 \%$ de pDCs em pacientes UCI e 0,39\% nos indivíduos sadios, não havendo diferença significativa ao compararmos os grupos entre si. De acordo com a literatura, o número de pDCs circulantes em humanos é muito baixo, cerca de 0,2-0,5\% das CMN (Feldman et al., 1995).

É possível que devido ao baixo número de pDCs circulantes seja difícil observar diferença entre controles e pacientes UCI, entretanto, seria interessante verificar se ocorre migração das pDCs para os sítios inflamatórios na pele. Nas lesões de doenças inflamatórias de pele, como a psoríase vulgaria e dermatite de contato, há um elevado número de pDCs e DCs inflamatórias epidermais (Wollenberg et al., 2002; Jahnsen et al., 2002). Nas lesões de pele de pacientes com Lúpus Eritematoso Sistêmico (SLE) há infiltração de grande número de pDCs ativadas produtoras de interferons do tipo I (Farkas et al., 2001; Cederblad et al., 1998). Além disto, diferentes padrões de distribuição das pDCs pode ser observado em biópsias de pele de pacientes, com 
localização na epiderme em casos de dermatomiosite e na derme no SLE (McNiff e Kaplan 2007).

Em contraste, nas biópsias de pele de pacientes UCI avaliados, verificamos um perfil com pouco infiltrado inflamatório e presença de raras células CD123+ ao longo do infiltrado inflamatório. De 16 casos de UCI, apenas cinco puderam ser avaliados quanto à presença da pDC nas lesões de pele. Apesar do pequeno número de casos avaliados até o momento, a diminuição da produção de IFN- $\alpha$ em resposta ao CpGA observada nos pacientes UCI não parece estar relacionada à migração e conseqüente presença da pDC na lesão de pele.

Outra possibilidade é que na UCI, poderia ocorrer uma alteração na capacidade de ativação das pDCs em resposta ao CpGA, e assim possibilitar a diminuição de IFN$\alpha$. Portanto, avaliamos a expressão de moléculas coestimulatórias em pDCs (Lin-/123+) em culturas estimuladas por CpGA. Observamos que o estímulo com CpGA é capaz de aumentar significantemente a intensidade de expressão das moléculas CD40 e CD80 e CD86 nas pDCs de pacientes e controles em relação às culturas não estimuladas. Não foi observada diferença entre a expressão destes marcadores quando comparamos controles e pacientes UCI indicando que a diminuição dos níveis de IFN- $\alpha$ após estímulo com CpGA parece não estar relacionado à capacidade de ativação das pDCs. Em contradição, foi descrito que na esclerose múltipla, não há diferença na expressão de CD40, CD80 e CD83 em pDCs de pacientes e controles, mas a expressão de CD86 e 4IBBL está diminuída nos pacientes, indicando um perfil imaturo das pDCs de pacientes com esclerose múltipla (Stasiolek et al., 2006).

A seguir, analisamos a expressão intracelular de IFN- $\alpha$ em pDCs após estímulo com CpGA e verificamos que há uma significante diminuição na expressão intracelular de IFN- $\alpha$ em pDCs de pacientes com UCI, quando comparados com indivíduos 
controles. Este dado confirma os resultados prévios obtidos em sobrenadantes de culturas, e mostra que a pDC é a população celular envolvida na produção de IFN- $\alpha$ em reposta ao CpGA.

Nossos resultados mostram que na UCI, não há alteração do percentual das pDCs no sangue periférico e que, embora a expressão intracelular de IFN- $\alpha$ esteja diminuída, verificamos uma ativação adequada em resposta ao CpGA. Este fato nos levou a investigar a expressão de TLR9 e o fator de transcrição IRF-7, expresso constitutivamente em altas concentrações pelas pDCs, responsável pela rápida síntese de IFN- $\alpha$. Uma baixa expressão de mRNA para TLR9 foi observada nos pacientes UCI após 8 horas de estímulo com CpGA. É possível que a diminuída produção de IFN- $\alpha$ por pacientes UCI seja uma conseqüência funcional da baixa expressão de TLR9 que por sua vez interfere na expressão de IRF-7. Uma das hipóteses para explicar a baixa expressão de TLR9 por pDCs após estímulo com CpGA pode ser a ligação com o FceRI. Têm sido descrito que a ligação da IgE com o FcєRI expresso por pDCs imaturas é capaz de suprimir a produção de IFN- $\alpha$ em resposta à ativação via TLR9 pelo CpG em indivíduos atópicos (Schroeder et al, 2005). Embora a diminuição das respostas imunes por pDCs humanas estejam associadas à processos alérgicos é inversamente correlacionada com a expressão de FceRIa e com os níveis séricos de IgE (Tversky et al., 2008). De fato, os níveis séricos de $\operatorname{IgE}$ se correlacionaram positivamente com a expressão de FceRI em basófilos na coorte de pacientes UCI (Lourenço et al., 2008).

Outros mecanismos podem estar implicados na regulação negativa da produção de IFN- $\alpha$ por pDCs após ativação via TLR9, como a expressão de moléculas de superfície ou efeito direto da histamina. Moléculas como BDCA2 (Dzionek et al., 2001), ILT7 (Cao et al. 2006), e NKp44 (Fuchs et al., 2005) são receptores regulatórios 
capazes de regular negativamente a produção de IFN- $\alpha$. Outra possibilidade é que a ação de mediadores produzidos durante o processo inflamatório/urticariforme em decorrência da desgranulação de basófilos ou mastócitos, seja mediada por autoanticorpos contra o FceRI ou a molécula IgE, ou outros fatores, como a histamina, podem regular vários tipos celulares. Foi demonstrado que pDCs humanas, ativadas CpG ou por infecção viral, respondem à histamina através dos receptores $\mathrm{H} 2$ levando a uma regulação negativa da produção de IFN- $\alpha$, explicando os baixos níveis de IFN- $\alpha$ observada em indivíduos atópicos (Mazzoni et al., 2003) 


\section{VII.CONCLUSÕES}




\section{CONCLUSÕES}

- A estimulação in vitro com adjuvante da resposta inata, CpGA, revelou uma deficiência de produção de IL-10 e IFN- $\alpha$ de leucócitos de pacientes UCI, efeito intensificado pelo ODN-S, que também foi capaz de estimular a produção de IL-12p40.

- A baixa resposta ao agonista de TLR9, não é conseqüente à diminuição percentual, ao grau de ativação de células dendríticas plasmocitóides no sangue periférico e a presença da pDC na lesão.

- Há uma baixa expressão intracelular de IFN- $\alpha$ em pDCs após estímulo com CpGA evidenciando uma alteração na via de sinalização por TLR9 nos pacientes UCI. 


\section{ANEXOS}


VIII. ANEXOS

TERMO DE CONSENTIMENTO LIVRE E ESCLARECIDO

(Instruções para preenchimento no verso)

\section{I - DADOS DE IDENTIFICAÇÃO DO SUJEITO DA PESQUISA OU RESPONSÁVEL LEGAL}

1.NOME DO PACIENTE.:

DOCUMENTO DE IDENTIDADE N ${ }^{\circ}$ : SEXO : .M F

DATA NASCIMENTO: .........................

ENDEREÇO $\mathrm{N}^{\mathrm{o}}$ APTO:

BAIRRO

CEP:

TELEFONE: DDD CIDADE

2.RESPONSÁVEL LEGAL

NATUREZA (grau de parentesco, tutor, curador etc.)

DOCUMENTO DE IDENTIDADE : SEXO: M F

DATA NASCIMENTO.

ENDEREÇO: .. $\mathrm{N}^{\circ}$ ..APTO:

BAIRRO: CIDADE:

CEP: TELEFONE: DDD

...).

\section{II - DADOS SOBRE A PESQUISA CIENTÍFICA}

1. TÍTULO DO PROTOCOLO DE PESQUISA "Caracterização fenotípica e grau de ativação de células dendríticas plasmocitóides ao estímulo in vitro com oligodeoxinucleotídeos CpG na Urticária Crônica"

PESQUISADOR: Maria Notomi Sato

CARGO/FUNÇÃO: Professor Doutor

INSCRIÇÃO CONSELHO REGIONAL $\mathrm{N}^{\circ}$ CRBM 1690

UNIDADE DO HCFMUSP: Departamento de Dermatologia

3. AVALIAÇÃO DO RISCO DA PESQUISA:

$\begin{array}{cccc}\text { SEM RISCO } \square & \text { RISCO MÍNIMO } & \mathbf{X} & \text { RISCO } \\ \text { MÉDIO } & \square & & \\ \text { RISCO BAIXO } \square & \text { RISCO MAIOR } & \square\end{array}$

(probabilidade de que o indivíduo sofra algum dano como consequência imediata ou tardia do estudo)

4.DURAÇÃO DA PESQUISA : 2 anos 


\section{III - REGISTRO DAS EXPLICAÇÕES DO PESQUISADOR AO PACIENTE OU SEU REPRESENTANTE LEGAL SOBRE A PESQUISA CONSIGNANDO:}

1. justificativa e os objetivos da pesquisa 2. procedimentos que serão utilizados e propósitos, incluindo a identificação dos procedimentos que são experimentais 3. desconfortos e riscos esperados 4 . benefícios que poderão ser obtidos $\mathbf{5}$. procedimentos alternativos que possam ser vantajosos para o indivíduo

O Laboratório de Dermatologia e Imunodeficiência (LIM 56) da Faculdade de Medicina da USP está desenvolvendo um estudo para melhor compreender a doença urticária crônica com o objetivo de desenvolver novos tipos de exames e tratamentos. Você está sendo convidado a participar voluntariamente (sem remuneração e de modo não obrigatório) neste estudo. Para isto é preciso coletar $20 \mathrm{ml}$ de sangue de seu braço. Você sentirá a picada da agulha e pode sentir uma leve tontura, que passará em poucos minutos. Um dia após pode aparecer em volta do local da picada uma mancha roxa que desaparece em poucos dias sem maiores problemas. Esta amostra de sangue será utilizada para o estudo de células e substâncias envolvidas no processo inflamatório da Urticária Crônica Autoimune. Este exame tem objetivo de esclarecer uma possível causa da doença urticária crônica e de modo a auxiliar no diagnóstico da doença.

No entanto, se você sentir qualquer tipo de desconforto, antes ou depois dos procedimentos, o médico estará a sua inteira disposição para solucionar o problema ou tirar as dúvidas.

Você não tem nenhuma obrigação de contribuir para este estudo e sua recusa não ocasionará nenhum prejuízo em seu atendimento médico dentro do HC.

\section{IV - ESCLARECIMENTOS DADOS PELO PESQUISADOR SOBRE GARANTIAS DO SUJEITO DA PESQUISA CONSIGNANDO:}

1. acesso, a qualquer tempo, às informações sobre procedimentos, riscos e benefícios relacionados à pesquisa, inclusive para dirimir eventuais dúvidas.

Estaremos a sua disposição para qualquer informação ou dúvida sobre o teste a ser realizado nesta pesquisa.

2. liberdade de retirar seu consentimento a qualquer momento e de deixar de participar do estudo, sem que isto traga prejuízo à continuidade da assistência.

Você não tem nenhuma obrigação de contribuir para este estudo e sua rcusa não ocasionará nenhum prejuízo em seu atendimento médico dentro do HC.

3. salvaguarda da confidencialidade, sigilo e privacidade.

Os dados obtidos poderão ser acessados somente pelos investigadores, comissão de ética da instituição e autoridades sanitárias do país.

4. disponibilidade de assistência no HC-FMUSP, por eventuais danos à saúde, decorrentes da pesquisa.

A pesquisa não envolve nenhum risco à sua saúde, mas qualquer eventualidade que possa ocorrer durante a coleta de sangue é assegurada a assistência por médicos do HC-FMUSP. 
5. viabilidade de indenização por eventuais danos à saúde decorrentes da pesquisa.

Em qualquer eventualidade que possa ocorrer durante a coleta de sangue será assegurada a assistência médica.

V. INFORMAÇÕES DE NOMES, ENDEREÇOS E TELEFONES DOS

RESPONSÁVEIS PELO ACOMPANHAMENTO DA PESQUISA, PARA CONTATO

EM CASO DE INTERCORRÊNCIAS CLÍNICAS E REAÇÕES ADVERSAS.

\section{OBSERVAÇÕES COMPLEMENTARES:}

\section{VII - CONSENTIMENTO PÓS-ESCLARECIDO}

Declaro que, após convenientemente esclarecido pelo pesquisador e ter entendido o que me foi explicado, consinto em participar do presente Protocolo de Pesquisa.

São Paulo, de de 2010

assinatura do sujeito da pesquisa ou responsável legal

assinatura do pesquisador

(carimbo ou nome Legível) 


\begin{abstract}
ANEXO B

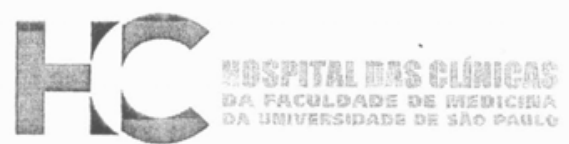

APROVAÇÃO

A Comissão de Ética para Análise de Projetos de Pesquisa - CAPPesq da Diretoria Clínica do Hospital das Clínicas e da Faculdade de Medicina da Universidade de São Paulo, em sessão de 22/08/2007, APROVOU o Protocolo de Pesquisa n ${ }^{\circ}$ 0569/07, intitulado: "CARActerização fenotípica e Grau de ativação de Células DENDRÍTICAS PLASMOCITÓIDES AO ESTÍMULO IN VITRO COM OLIGODEOXINUCLEOTÍDEOS CPG NA URTICÁRIA CRÔNICA" apresentado pelo Departamento de DERMATOLOGIA, inclusive O Termo de Consentimento Livre e Esclarecido.
\end{abstract}

Cabe ao pesquisador elaborar e apresentar à CAPPesq, os relatórios parciais e final sobre a pesquisa (Resolução do Conselho Nacional de Saúde $n^{\circ} 196$, de 10/10/1996, inciso IX.2, letra "c").

Pesquisador (a) Responsável: Maria Notomi Sało

Pesquisador (a) Executante: Eliana Akemi Futata Taniguchi

CAPPesq, 24 de Agosto de 2007

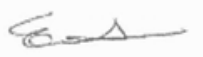

Prof. Dr. Eduardo Massad Presidente da Comissão de Ética para Análise de Projetos de Pesquisa

Comissão de Ética para Análise de Projetos de Pesquisa do HCFMUSP e da FMUSP Diretoria Clinica do Hospital das Clinicas da Faculdade de Medicina da Universidade de São Paulo Rua Ovidio Pires de Campos, 255, $5^{\circ}$ andar - CEP 05403010 - São Paulo - SP Fone: 0113069 6442 Fax: 01130696492 e-mail: cappesq@hcnet. usp.br/ secretariacappesq2@hcnet.usp.br sol 
ANEXO C: Características individuais dos pacientes com Urticária Crônica Idiopática

\begin{tabular}{|c|c|c|c|c|c|c|c|c|c|}
\hline Paciente & Sexo & Idade & $\begin{array}{c}\text { Duração da doença } \\
\text { (anos) }\end{array}$ & ASST & Angiodema & FAN & Anti-TPO & Anti-TG & Tireopatia \\
\hline UCI 1 & $\mathrm{~F}$ & 39 & 16 & - & - & - & - & - & - \\
\hline UCI 2 & $\mathrm{~F}$ & 30 & 7 & - & - & - & - & - & - \\
\hline UCI 3 & F & 51 & 5 & - & + & - & - & - & + \\
\hline UCI 4 & $\mathrm{~F}$ & 40 & NC & - & NC & - & - & - & - \\
\hline UCI 5 & F & 54 & 19 & - & + & - & - & - & + \\
\hline UCI 6 & M & 61 & 4 & - & + & - & - & - & + \\
\hline UCI 7 & $\mathrm{~F}$ & 55 & 4 & + & + & - & - & - & - \\
\hline UCI 8 & $\mathrm{~F}$ & 45 & 7 & + & + & - & - & + & - \\
\hline UCI 9 & $\mathrm{~F}$ & 55 & 31 & + & + & - & - & - & - \\
\hline UCI 10 & $\mathrm{~F}$ & 62 & 9 & - & + & - & - & - & - \\
\hline UCI 11 & $\mathrm{~F}$ & 42 & NC & - & NC & - & - & - & - \\
\hline UCI 12 & $\mathrm{~F}$ & 41 & 3 & - & - & - & - & - & - \\
\hline UCI 13 & $\mathrm{~F}$ & 42 & 10 & - & - & - & 289 & 1696 & - \\
\hline UCI 14 & $\mathrm{~F}$ & 52 & 6 & + & + & - & - & - & - \\
\hline UCI 15 & $\mathrm{~F}$ & 38 & 3 & + & + & - & - & - & - \\
\hline UCI 16 & M & 22 & 1,5 & + & + & - & - & - & - \\
\hline UCI 17 & F & 57 & 57 & - & + & + & - & - & - \\
\hline
\end{tabular}

UCI :Urticária Crônica Idiopática, NC: Não Consta, ND: Não Determinado, ASST: Autologous Serum Skin Test, FAN: Anticorpo Anti-Nuclear, TG: Anticorpo Anti-Tireoglobulina e TPO: Anticorpo Anti-Tireoperoxidase. 
Tabela 2 (continuação): Características individuais dos pacientes com Urticária Crônica Idiopática

\begin{tabular}{|c|c|c|c|c|c|c|c|c|c|}
\hline Paciente & Sexo & Idade & $\begin{array}{c}\text { Duração da doença } \\
\text { (anos) }\end{array}$ & ASST & Angiodema & FAN & TPO & TG & Tireopatia \\
\hline UCI 18 & $\mathrm{~F}$ & 61 & 8 & + & - & + & 1079 & - & - \\
\hline UCI 19 & F & 65 & 34 & - & + & - & NC & $\mathrm{NC}$ & - \\
\hline UCI 20 & $\mathrm{~F}$ & 22 & NC & + & NC & NC & - & - & - \\
\hline UCI 21 & $\mathrm{~F}$ & 58 & NC & - & NC & - & - & - & - \\
\hline UCI 22 & $\mathrm{~F}$ & 38 & 3 & + & + & - & - & - & - \\
\hline UCI 23 & $\mathrm{~F}$ & 60 & ND & ND & ND & ND & ND & ND & ND \\
\hline UCI 24 & $\mathrm{~F}$ & 65 & ND & ND & ND & ND & ND & ND & ND \\
\hline UCI 25 & $\mathrm{~F}$ & 37 & ND & ND & ND & ND & ND & ND & ND \\
\hline UCI 26 & $\mathrm{~F}$ & 62 & ND & ND & ND & ND & ND & ND & ND \\
\hline
\end{tabular}

nuclear, TG: Anticorpo anti-tireoglobulina e TPO: Anticorpo anti- tireoperoxidase. 


\section{REFERÊNCIAS BIBLIOGRÁFICAS}




\section{REFERÊNCIAS BIBLIOGRÁFICAS}

Ajjan RA, Weetman AP. Cytokines and thyroid autoimmunity. Autoimmunity, 2003; 36(6-7):351-9.

Akira S. Toll-like receptors and innate immunity.Adv. Immunol. 2001; 78:1-56.

Asero R, Tedeschi A, Coppola R, Griffini S, Paparella P, Riboldi P, Marzano A V, Fanoni D, Cugno M. Activation of the tissue factor pathway of blood coagulation in patients with chronic urticaria. J Allergy Clin Immunol. 2007; 119(3):705-10.

Asero R, Tedeschi A, Riboldi P, Griffini S, Bonanni E, Cugno, M. Coagulation cascade and fibrinolysis in patients with multiple-drug allergy syndrome. Ann Allergy Asthma Immunol. 2008; 100(1):44-8.

Asero R, Tedeschi A, Riboldi P, Griffini S, Bonanni E, Cugno M. Severe chronic urticaria is associated with elevated plasma levels of D-dimer. Allergy, 2008; 63(2):176-80.

Ashman RF, Goeken JA, Drahos J, Lenert, P. Sequence requirements for oligodeoxyribonucleotide inhibitory activity. Int Immunol. 2005; 17(4):411-20.

Ashman RF, Goeken JA, Drahos J, Lenert P. Sequence requirements for oligodeoxyribonucleotide inhibitory activity. Int. Immunol. 2005;17(4):411-20.

Banchereau J, Steinman RM. Dendritic cells and the control of immunity. Nature. 1998 Mar 19;392(6673):245-52.

Bauer S, Wagner H. Bacterial CpG-DNA licenses TLR9. Curr. Top. Microbiol. Immunol. 2002; 270:145-54.

Bave U, Magnusson M, Eloranta ML, Perers A, Alm GV, Rönnblom L. Fc gamma RIIa is expressed on natural IFN-alpha-producing cells (plasmacytoid dendritic cells) and is required for the IFN-alpha production induced by apoptotic cells combined with lupus IgG. J Immunol. 2003;5;171(6):3296-302.

Bendriss-Vermare N, Burg S, Kanzler H, Chaperot L, Duhen T, De Bouteiller O, D'agostini M, Bridon JM, Durand I, Sederstrom JM, Chen W, Plumas J, Jacob MC, Liu YJ, Garrone P, Trinchieri G, Caux C, Brière F. Virus overrides the propensity of human CD40L-activated plasmacytoid dendritic cells to produce Th2 mediators through synergistic induction of IFN-\{gamma $\}$ and Th1 chemokine production. J Leukoc Biol. 2005;78(4):954-66.

Berghöfer B, Haley G, Frommer T, Bein G, Hackstein H. J. Natural and synthetic TLR7 ligands inhibit CpG-A- and CpG-C-oligodeoxynucleotide-induced IFN-alpha production. Immunol. 2007; 178(7):4072-9. 
Biron CA. Interferons alpha and beta as immune regulators--a new look. Immunity, 2001;14(6):661-4.

Cao W, Rosen DB, Ito T, Bover L, Bao M, Watanabe G, et al. Plasmacytoid dendritic cell-specific receptor ILT7-Fc epsilonRI gamma inhibits Toll-like receptor-induced interferon production. J Exp Med. 2006; 12;203(6):1399-405.

Caproni M, Giomi B, Volpi W, Melani L, Schincaglia E, Macchia D, Manfredi M, D'agata A, Fabbri P. Chronic idiopathic urticaria: infiltrating cells and related cytokines in autologous serum-induced wheals. Clin. Immunol. 2005; 114: 284-292.

Caron G, Delneste Y, Roelandts E, Duez C, Herbault N, Magistrelli G, Bonnefoy JY, Pestel J, Jeannin P. Histamine induces CD86 expression and chemokine production by human immature dendritic cells.J Immunol. 2001a;166(10):6000-6.

Cederblad B, Blomberg S, Vallin H, Perers A, Alm G V, Rönnblom L. Patients with systemic lupus erythematosus have reduced numbers of circulating natural interferonalpha- producing cells. J Autoimmun. 1998; 11(5):465-70.

Confino-Cohen R, Goldberg A, Aharoni D, Naimam L, Buchs A, Weiss M, Weissgarten J, Rapoport MJ. Low stimulated IL-4 secretion in PBMC from patients with chronic idiopathic urticaria. Cytokine, 2004;27: 74-80.

Cribier B. Urticaria and hepatitis. Clin Rev Allergy Immunol. 2006, 30(1):25-9.

Dajee M, Muchamuel T, Schryver BOOA.; Alleman-Sposeto J, De Vry CG, Prasad S, Ruhrmund D, Shyamsundar R, Mutnick D, Mai K, Le T, Parham C, Zhang J, Komuves L, Colby T, Hudak S, Mcevoy LM, Ehrhardt RO. Blockade of experimental atopic dermatitis via topical NF-kappaB decoy oligonucleotide. J Invest Dermatol. 2006; 126(8):1792-803.

Dos Santos JC, Azor MH, Nojima VY, Lourenço FD, Prearo E, Maruta CW, Rivitti EA, Da Silva Duarte AJ, Sato MN. Increased circulating pro-inflammatory cytokines and imbalanced regulatory $\mathrm{T}$-cell cytokines production in chronic idiopathic urticaria. Int Immunopharmacol. 2008;8(10):1433-40.

Doutre MS. Chronic urticaria and thyroid auto-immunity. Clin Rev Allergy Immunol, 2006;30(1):31-7.

Dreskin SC, Andrews KY. The thyroid and urticaria. Curr Opin Allergy Clin Immunol. 2005;5(5):408-12.

Dumitriu IE, Baruah P, Bianchi ME, Manfredi AA, Rovere-Querini P. Requirement of HMGB1 and RAGE for the maturation of human plasmacytoid dendritic cells. Eur $\mathrm{J}$ Immunol. 2005;35(7):2184-90.

Duramad O, Fearon KL, Chan JH, Kanzler H, Marshall JD, Coffman RL, Barrat FJ. IL10 regulates plasmacytoid dendritic cell response to $\mathrm{CpG}$-containing mmunostimulatory sequences. Blood. 2003;102(13):4487-92. 
Duramad O, Fearon KL, Chang B, Chan JH, Gregorio J, Coffman RL, Barrat FJ. Inhibitors of TLR-9 act on multiple cell subsets in mouse and man in vitro and prevent death in vivo from systemic inflammation. J Immunol. 2005;174(9):5193-200.

Dzionek A, Sohma Y, Nagafune J, Cella M, Colonna M, Facchetti F, Gunther G, Johnston I, Lanzavecchia A, Nagasaka T, Okada T, Vermi W, Winkels G, Yamamoto T, Zysk M, Yamaguchi Y, Schmitz J. BDCA-2, a novel plasmacytoid dendritic cellspecific type II C-type lectin, mediates antigen capture and is a potent inhibitor of interferon alpha/beta induction. J. Exp. Med. 2001;194(12):1823-34.

Eckman JA, Hamilton RG, Gober LM, Sterba PM, Saini, SS. Basophil phenotypes in chronic idiopathic urticaria in relation to disease activity and autoantibodies. J Invest Dermatol. 2008;128(8):1956-63.

Fanning SL, George TC, Feng D, Feldman SB, Megjugorac NJ, Izaguirre AG, Fitzgerald-Bocarsly P. Receptor cross-linking on human plasmacytoid dendritic cells leads to the regulation of IFN-alpha production. J Immunol, 2006;177(9):5829-39.

Farkas L, Beiske K, Lund-Johansen F, Brandtzaeg P, Jahnsen FL. Plasmacytoid dendritic cells (natural interferon- alpha/beta-producing cells) accumulate in cutaneous lupus erythematosus lesions. Am J Pathol. 2001;159(1):237-43.

Feldman SB, Milone MC, Kloser P, Fitzgerald-Bocarsly P. Functional deficiencies in two distinct interferon alpha-producing cell populations in peripheral blood mononuclear cells from human immunodeficiency virus seropositive patients. J Leukoc Biol. 1995;57(2):214-20.

Ferrer ME, Luquin A, Sanchez-Ibarrola C, Moreno ML, Sanz EAP. Kaplan A. Secretion of cytokines, histamine and leukotrienes in chronic urticaria. Int Arch Allergy Immunol. 2002;129(3):254-60.

Fuchs A, Cella M, Kondo T, Colonna M. Paradoxic inhibition of human natural interferon-producing cells by the activating receptor NKp44. Blood. 2005 Sep 15;106(6):2076-82.

Gestermann N, Mekinian A, Comets E, Loiseau P, Puechal X, Hachulla E, Gottenberg JE, Mariette X, Miceli-Richard C. STAT4 is a confirmed genetic risk factor for Sjögren's syndrome and could be involved in type 1 interferon pathway signaling.Genes Immun. $2010 \mathrm{Jul} ; 11(5): 432-8$.

Grattan CE, Dawn G, Gibbs S, Francis DM. Blood basophil numbers in chronic ordinary urticaria and healthy controls: diurnal variation, influence of loratadine and prednisolone and relationship to disease activity. Clin Exp Allergy. 2003;33(3):337-41.

Greaves MW. Chronic idiopathic urticaria. Curr Opin Allergy Clin Immunol. 2003;3(5):363-8.

Gursel I, Gursel M, Yamada H, Ishii KJ, Takeshita F, Klinman DM. Repetitive elements in mammalian telomeres suppress bacterial DNA-induced immune activation. J Immunol. 2003;171(3):1393-400. 
Hartmann G, Battiany J, Poeck H, Wagner M, Kerkmann M, Lubenow S, Rothenfusser $\mathrm{S}$, Endres S. Rational design of new $\mathrm{CpG}$ oligonucleotides that combine $\mathrm{B}$ cell activation with high IFN- $\alpha$ induction in plasmacytoid dendritic cells. Eur. J. Immunol. 2003;33: 1633-1641.

Hein R. Chronic urticaria: impact of allergic inflammation. Allergy 2002;57(75):19-24.

Hemmi H, Kaisho T, Takeda K, Akira S. The roles of Toll-like receptor 9, MyD88, and DNA-dependent protein kinase catalytic subunit in the effects of two distinct CpG DNAs on dendritic cell subsets. J. Immunol. 2003;170(6):3059-64.

Hemmi H, Kaisho T, Takeuchi O, Sato S, Sanjo H, Hoshino K, Horiuchi T, Tomizawa H, Takeda K, Akira S. Small anti-viral compounds activate immune cells via the TLR7 MyD88-dependent signaling pathway. Nat. Immunol. 2002; 3(2):196-200.

Ho PP, Fontoura P, Ruiz PJ, Steinman L, Garren H. An immunomodulatory CpG oligonucleotide for the treatment of autoimmunity via innate and adaptive immune systems. J. Immunol. 2003;171:4920-4926.

Hückel M, Schurigt U, Wagner AH, Stöckigt R, Petrow P, Thoss K, Gajda M, Henzgen $\mathrm{S}$, Hecker M, Bräuer R. Attenuation of murine antigen-induced arthritis by treatment with a decoy oligodeoxynucleotide inhibiting signal transducer and activator of transcription-1 (STAT-1). Arthritis research Therapy, 2006;8:1-13.

Ito T, Kanzler H, Duramad O, Cao W, Liu YJ. Specialization, kinetics, and repertoire of type 1 interferon responses by human plasmacytoid predendritic cells. Blood, 2006;107(6):2423-31.

Izaguirre A, Barnes BJ, Amrute S, Yeow WS, Megjugorac N, Dai J, Feng D, Chung E, Pitha PM, Fitzgerald-Bocarsly P. Comparative analysis of IRF and IFN-alpha expression in human plasmacytoid and monocyte-derived dendritic cells.J Leukoc Biol, 2003;74(6):1125-38.

Izaguirre A, Barnes BJ, Amrute S, Yeow, WS, Megjugorac N, Dai J, Feng D, Chung E, Pitha PM, Fitzgerald-Bocarsly, P. Comparative analysis of IRF and IFN-alpha expression in human plasmacytoid and monocyte-derived dendritic cells. J Leukoc Biol. 2003; 74(6):1125-38.

Janeway CAJ. How the immune system protects the host from infection. Microbes Infect. 2001; 3(13):1167-71.

Jego G, Palucka AK, Blanck JP, Chalouni C, Pascual V, Banchereau J. Plasmacytoid dendritic cells induce plasma cell differentiation through type I interferon and interleukin 6.Immunity, 2003; 19(2):225-34.

Jirapongsananuruk O, Pongpreuksa, S, Sangacharoenkit P, Visitsunthorn N, Vichyanond P. Identification of the etiologies of chronic urticaria in children: A prospective study of 94 patients. Pediatr Allergy Immunol. 2009 Jun 25. 
Kadowaki N, Ho S, Antonenko S, Malefyt RW, Kastelein RA, Bazan F, Liu YJ. Subsets of human dendritic cell precursors express different toll-like receptors and respond to different microbial antigens. J Exp Med, 2001;194(6):863-9.

Kalinski P, Schuitemaker JH, Hilkens CM, Kapsenberg, ML. Prostaglandin E2 induces the final maturation of IL-12-deficient CD1a+CD83+ dendritic cells: the levels of IL-12 are determined during the final dendritic cell maturation and are resistant to further modulation. J. Immunol. 1998; 15;161(6):2804-9.

Kaplan AP, Greaves M. Pathogenesis of chronic urticaria. Clin Exp Allergy 2009;39(6):777-87.

Kaplan AP, Joseph K. Basophil secretion in chronic urticaria: autoantibody-dependent or not? J Allergy Clin Immunol. 2007;120(3):729-30.

Kariuki SN, Moore JG, Kirou KA, Crow MK, Utset TO, Niewold TB. Age- and genderspecific modulation of serum osteopontin and interferon-alpha by osteopontin genotype in systemic lupus erythematosus. Genes Immun. 2009 Jul;10(5):487-94.

Kawai T, Sato S, Ishii KJ, Coban C, Hemmi H, Yamamoto M, Terai K, Matsuda M, Inoue J, Uematsu S, Takeuchi O, Akira S. Interferon-alpha induction through Toll-like receptors involves a direct interaction of IRF7 with MyD88 and TRAF6. Nat. Immunol. 2004; 5(10):1061-8.

Kerkmann M, Rothenfusser S, Hornung V, Towarowski, A, Wagner M, Sarris A, Giese T, Endres S, Hartmann G. Activation with CpG-A and CpG-B oligonucleotides reveals two distinct regulatory pathways of type I IFN synthesis in human plasmacytoid dendritic cells. J. Immunol. 2003;170(9):4465-74.

Kikuchi Y, Fann T, Kaplan AP. Antithyroid antibodies, in chronic urticaria and angioedema. J. Allergy Clin Immunol. 2003, 218.

Klinman DM, Gursel I, Klaschik S, Dong L, Currie D, Shirota H. Therapeutic Potential of Oligonucleotides Expressing Immunosuppressive TTAGGG Motifs. Ann N Y Acad Sci. 2005;1058:87-95.

Krieg AM. CpG motifs in bacterial DNA and their immune effects. Annu. Rev. Immunol. 2002; 20:709-760.

Krieg AM, Wu T, Weeratna R, Efler SM, Love L, Yang L, YI A, Short D, Davis HL. Sequence motifs in adenoviral DNA block immune activation by stimulatory CpG motifs. Proc. Natl. Acad. Sci. 1998; 95:12631.

Krug A, Rothenfusser S, Hornung V, Jahrsdorfer B, Blackwell S, Ballas ZK, Endres S, Krieg AM, Hartmann G. Identification of $\mathrm{CpG}$ oligonucleotide sequences with high induction of IFN-alpha/beta in plasmocytoid dendritic cells. Eur. J. Immunol. 2001; 31:2154-2163.

Lenert P. Inhibitory oligodeoxynucleotides - therapeutic promise for systemic autoimmune diseases? Clin. Exp. Immunol. 140:1-10, 2005. 
Lenert P, Stunz L, Yi AK, Krieg AM, Ashman RF. CpG stimulation of primary mouse $\mathrm{B}$ cells is blocked by inhibitory oligodeoxyribonucleotides at a site proximal to NF- $\kappa \mathrm{B}$ activation. Antisense Nucleic Acid. Drug. 2001;11:247.

Lourenço FD, Azor MH, Santos JC, Prearo E, Maruta CW, Rivitti EA, Duarte AJ, Sato MN. Activated status of basophils in chronic urticaria leads to interleukin-3 hyperresponsiveness and enhancement of histamine release induced by anti-IgE stimulus. $\mathrm{Br}$ J Dermatol. 2008;158(5):979-86.

Lui G, Manches O, Angel J, Molens JP, Chaperot L, Plumas J. Plasmacytoid dendritic cells capture and cross-present viral antigens from influenza-virus exposed cells. PLoS One, 2009; 22;4(9):7111.

Macfarlane DE, Manzel L. Antagonism of immunostimulatory CpGoligodeoxynucleotides by quinacrine, chloroquine, and structurally related compounds. J Immunol. 1998, 160(3):1122-31.

Macglashan DWJ. Relationship between spleen tyrosine kinase and phosphatidylinositol $5^{\prime}$ phosphatase expression and secretion from human basophils in the general population. J Allergy Clin Immunol. 2007, 119(3):626-33.

Mazzoni A, Leifer CA, Mullen GE, Kennedy MN, Klinman DM, Segal DM. Cutting edge: histamine inhibits IFN-alpha release from plasmacytoid dendritic cells. J Immunol. 2003 Mar 1;170(5):2269-73.

Mcniff JM, Kaplan DH. Plasmacytoid dendritic cells are present in cutaneous dermatomyositis lesions in a pattern distinct from lupus erythematosus. J Cutan Pathol., 2008;35(5):452-6.

Megjugorac NJ, Young HA, Amrute SB, Olshalsky SL, Fitzgerald-Bocarsly P. Virally stimulated plasmacytoid dendritic cells produce chemokines and induce migration of $\mathrm{T}$ and NK cells. J Leukoc Biol. 2004; 75(3):504-14.

Najjar I, Fagard R. STAT1 and pathogens, not a friendly relationship. Biochimie. 2010 May;92(5):425-44.

Niessner A, Sato K, Chaikof EL, Colmegna I, Goronzy JJ, Weyand CM. Pathogensensing plasmacytoid dendritic cells stimulate cytotoxic T-cell function in the atherosclerotic plaque through interferon-alpha. Circulation 2006;114(23):2482-9.

Niimi NDM, Francis F, Kermani BF, O'donnell M, Hide A, Kobza-Black RK, Winkelmann MW, Greaves ERM. Barr. Dermal mast cell activation by autoantibodies against the high affinity $\operatorname{IgE}$ receptor in chronic urticaria. J Invest Dermatol. 1996;106(5):1001-6.

O'Donnell BF, Lawlor F, Simpson J, Morgan M, Greaves MW. The impact of chronic urticaria on the quality of life. Br J Dermatol. 1997; 136(2):197-201. 
Platanias LC. Introduction: interferon signals: what is classical and what is non classical? J Interferon Cytokine Res. 2005 Dec;25(12):732.

Piconi SD, Trabattoni E, Iemoli ML, Fusi ML, Villa F, Milazzo, EM. Immune profiles of patients with chronic idiopathic urticaria. Int Arch Allergy Immunol. 2002;128(1):59-66.

Ring JK, Brockow M, Ollert ER. Antihistamines in urticaria. Clin Exp Allergy 1999;29 ( 1$), 31-7$.

Rothenfusser S, Hornung V, Ayyoub M, Britsch S, Towarowski A, Krug A, Sarris A, Lubenow N, Speiser D, Endres S, Hartmann G. CpG-A and CpG-B oligonucleotides differentially enhance human peptide-specific primary and memory CD8+ T-cell responses in vitro. Blood. 2003;103(6):2162-9.

Sabroe RAE, Grattan DM, Francis RM, Barr A, Kobza Black EMW, Greaves MW. The autologous serum skin test: a screening test for autoantibodies in chronic idiopathic urticaria. Br J Dermatol, 1999;140(3):446-52.

Sabroe RAE, Fiebiger DM, Francis D, Maurer PT, Seed CE, Grattan AK, Black G, Stingl MW, Greaves ERM. Classification of anti-FcepsilonRI and anti-IgE autoantibodies in chronic idiopathic urticaria and correlation with disease severity. $\mathrm{J}$ Allergy Clin Immunol. 2002;110(3):492-9.

Saini SS. Basophil responsiveness in chronic urticaria. Curr Allergy Asthma Rep. 2009 Jul;9(4):286-90.

Sallusto F, Lanzavecchia A. Efficient presentation of soluble antigen by cultured human dendritic cells is maintained by granulocyte/macrophage colony-stimulating factor plus Interleukin 4 and downregulated by tumor necrosis factor alpha. J Exp Med. 1994;179(4):1109-18.

Sandberg K, Eloranta ML, Gobl AE, Alm GV. Phorbol ester-mediated inhibition of IFN-alpha/beta gene transcription in blood mononuclear leukocytes.J Immunol. 1991, 147(9):3116-21.

Schroeder JT, Bieneman AP, Xiao H, Chichester KL, Vasagar K, Saini S, Liu MC. TLR9- and FcepsilonRI-mediated responses oppose one another in plasmacytoid dendritic cells by down-regulating receptor expression. J Immunol. 2005 Nov $1 ; 175(9): 5724-31$

Shirota H, Gursel M, Klinman DM. Suppressive oligodeoxynucleotides inhibit Th1 differentiation by blocking IFN-gamma- and IL-12-mediated signaling. J Immunol, 2004; 173(8):5002-7.

Siegal FP, Kadowaki N, Shodell M, Fitzgerald-Bocarsly PA, Shah K, Ho S, Antonenko, $\mathrm{S}$, Liu, YJ. The nature of the principal type 1 interferon-producing cells in human blood. Science 1999;284(5421):1835-7. 
Stasiolek M, Bayas A, Kruse N, Wieczarkowiecz A, Toyka KV, Gold R, Selmaj K. Impaired maturation and altered regulatory function of plasmacytoid dendritic cells in multiple sclerosis. Brain. 2006 May;129(Pt 5):1293-305.

Stunz LL, Lenert P, Peckham D, Yi AK, Haxhinasto S, Chang M, Krieg AM, Ashman RF. Inhibitory oligonucleotides specifically block effects of stimulatory CpG oligonucleotides in B cells. Eur. J. Immunol. 2002; 32(5):1212-22.

Takahagi S, Mihara S, Iwamoto K, Morioke S, Okabe T, Kameyoshi Y, Hide M. Coagulation/fibrinolysis and inflammation markers are associated with disease activity in patients with chronic urticaria. Allergy. 2009 Oct 20.

Takaoka A, Yanai H, Kondo S, Duncan G, Negishi H, Mizutani T, Kano S, Honda K, Ohba Y, Mak TW, Taniguchi T. Integral role of IRF-5 in the gene induction programme activated by Toll-like receptors. Nature 2005;434(7030):243-9.

Takauji R, Iho S, Takatsuka H, Yamamoto S, Takahashi T, Kitagawa H, Iwasaki H, Iida R, Yokochi T, Matsuki T. CpG-DNA-induced IFN-alpha production involves p38 MAPK-dependent STAT1 phosphorylation in human plasmacytoid dendritic cell precursors. J Leukoc Biol. 2002;72(5):1011-9.

Tilton JC, Manion MM, Luskin MR, Johnson AJ, Patamawenu AA, Hallahan CW, Cogliano-Shutta NA, Mican JM, Davey RTJ, Kottilil S, Lifson JD, Metcalf JA, Lempicki RA, Connors M. Human immunodeficiency virus viremia induces plasmacytoid dendritic cell activation in vivo and diminished alpha interferon production in vitro.J Virol, 2008;82(8):3997-4006.

Trieu A, Roberts T L, Dunn JA, Sweet MJ, Stacey K J. DNA motifs suppressing TLR9 responses. Crit Rev Immunol. 2006 ; 26(6):527-44.

Tversky JR, Le TV, Bieneman AP, Chichester KL, Hamilton RG, Schroeder JT. Human blood dendritic cells from allergic subjects have impaired capacity to produce interferon-alpha via Toll-like receptor 9. Clin Exp Allergy. 2008 May;38(5):781-8.

Vanbervliet B, Bendriss-Vermare N, Massacrier C, Homey B, De Bouteiller O, Brière F, Trinchieri G, Caux C. The inducible CXCR3 ligands control plasmacytoid dendritic cell responsiveness to the constitutive chemokine stromal cell-derived factor 1 (SDF1)/CXCL12. J Exp Med. 2003;198(5):823-30.

Vonakis BM, Vasagar K, Gibbons SPJr, Gober L, Sterba PM, Chang H, Saini SS. Basophil FcepsilonRI histamine release parallels expression of Src-homology 2containing inositol phosphatases in chronic idiopathic urticaria. J Allergy Clin Immunol. 2007; 119(2):441-8.

Wollenberg A, Wagner M, Günther S, Towarowski A, Tuma E, Moderer M, Rothenfusser S, Wetzel S, Endres S, Hartmann G. Plasmacytoid dendritic cells: a new cutaneous dendritic cell subset with distinct role in inflammatory skin diseases. J Invest Dermatol. 2002 Nov;119(5):1096-102. 
Zawar V, Godse K, Sankalecha S. Chronic urticaria associated with recurrent genital herpes simplex infection and success of antiviral therapy - a report of two cases. Int $\mathbf{J}$ Infect Dis. 2010;14:e514-7. 